\author{
UNIVERSIDADE DE SÃO PAULO \\ FACULDADE DE ECONOMIA, ADMINISTRAÇÃO E CONTABILIDADE DE \\ RIBEIRÃO PRETO \\ DEPARTAMENTO DE ADMINISTRAÇÃO \\ PROGRAMA DE PÓS-GRADUAÇÃO EM ADMINISTRAÇÃO DE ORGANIZAÇÕES
}

FELIPE FURLAN SORIANO

Gestão da armazenagem: uma análise do sistema de gestão WMS

Orientador: Prof. Dr. Alexandre Pereira Salgado Junior

RIBEIRÃO PRETO

2013 
Prof. Dr. João Grandino Rodas

Reitor da Universidade de São Paulo

Prof. Dr. Sigismundo Bialoskorski Neto

Diretor da Faculdade de Economia, Administração e Contabilidade de Ribeirão Preto

Profa. Dra. Sonia Valle Walter Borges de Oliveira

Chefe do Departamento de Administração 


\section{FELIPE FURLAN SORIANO}

Gestão da armazenagem: uma análise do sistema de gestão WMS

Dissertação apresentada ao Programa de PósGraduação em Administração de Organizações da Faculdade de Economia, Administração e Contabilidade de Ribeirão Preto da Universidade de São Paulo, para obtenção do título de Mestre em Ciências. Versão Corrigida. A original encontra-se disponível no Serviço de Pós-Graduação da FEA-RP/USP.

Orientador: Prof. Dr. Alexandre Pereira Salgado Junior 
Autorizo a reprodução e divulgação total ou parcial deste trabalho, por meio convencional ou eletrônico, para fins de estudo e pesquisa, desde que citada a fonte.

Soriano, Felipe Furlan

Gestão da armazenagem: uma análise do sistema de gestão WMS. Ribeirão Preto, 2013.

110 f. : il.; $30 \mathrm{~cm}$.

Dissertação de Mestrado, apresentada à Faculdade de Economia, Administração e Contabilidade de Ribeirão Preto/USP.

Orientador: Salgado Junior, Alexandre Pereira

1. Gestão da Armazenagem. 2. TI aplicada à armazenagem. 3. WMS. 


\section{FOLHA DE APROVAÇÃO}

Nome: Felipe Furlan Soriano

Título: Gestão da armazenagem: uma análise do sistema de gestão WMS.

Dissertação apresentada ao Programa de PósGraduação em Administração da Faculdade de Economia, Administração e Contabilidade de Ribeirão Preto da Universidade de São Paulo como requisito para obtenção do título de Mestre em Ciências.

Aprovado em:

Banca Examinadora

Prof. Dr.

Instituição:

Julgamento:

Assinatura:

Prof. Dr.

Instituição:

Julgamento:

Assinatura:

Prof. Dr. Instituição:

Julgamento:

Assinatura: 


\section{DEDICATÓRIA}

Dedico este trabalho à minha família que desde sempre me incentivou na busca pelos meus objetivos. Essa conquista também é de vocês. 


\section{AGRADECIMENTOS}

Primeiramente, agradeço ao meu orientador, incentivador e amigo Prof. Dr. Alexandre Pereira Salgado Junior pelos ensinamentos transmitidos, contribuições significativas para o meu desenvolvimento pessoal e profissional.

Às cinco organizações participantes da pesquisa que, de boa vontade, colaboraram e disponibilizaram informações, enriquecendo a presente dissertação.

Aos professores Kleber Francisco Esposto, Marcio Mattos Borges de Oliveira, Marco Meda e Tarcísio Marcelo Menezes pelas diversas contribuições acadêmicas.

Agradeço também a Vania, Érika e Matheus, funcionários do Serviço de PósGraduação da FEA-RP/USP, pela dedicação e pelo suporte ao longo da realização do mestrado.

Aos colegas de sala de aula e todos que, direta ou indiretamente, colaboraram para a conclusão desta pesquisa.

Por fim, deixo aqui registrada a minha enorme gratidão à Universidade de São Paulo. 
EPÍGRAFE

"Viver pra ser melhor, também é um jeito de levar a vida." 


\section{RESUMO}

SORIANO, F. S. Gestão da Armazenagem: uma análise do sistema de gestão WMS. 2013. 110 f. Dissertação (Mestrado) - Faculdade de Economia, Administração e Contabilidade de Ribeirão Preto, Universidade de São Paulo, Ribeirão Preto, 2013.

Esta dissertação teve por objetivo analisar a influência do sistema de gestão de armazenagem (WMS) nas organizações usuárias estudadas, a partir da pesquisa bibliográfica realizada acerca do tema estabelecido e da análise de conteúdo das informações provenientes das entrevistas semiestruturadas efetuadas num estudo multicasos envolvendo duas empresas desenvolvedoras do software WMS e três organizações usuárias desta ferramenta. Dessa forma, foi possível identificar e analisar os pontos fortes e fracos do sistema, bem como as funcionalidades atualmente oferecidas ao mercado. Após a análise de tais informações, pode-se concluir que os fatores-chave para que ocorra uma implantação bem-sucedida do sistema são: o apoio da alta gerência, a realização prévia de um treinamento do pessoal envolvido na operação, o bom mapeamento e formalização dos processos organizacionais da empresa usuária, assim como a execução de um cadastro assertivo de produtos e endereços. Dentre os benefícios provenientes da adoção do sistema, além daqueles mencionados pela literatura, identificou-se a ocorrência de uma maior satisfação e motivação da equipe operacional, em virtude da mudança para uma rotina de trabalho mais organizada. Por fim, como tendências para o aprimoramento do WMS foi relatado: a integração do sistema com a tecnologia RFID, o desenvolvimento de novos relatórios gerenciais e a vinculação da mobilidade à ferramenta, disponibilizando o seu uso via tablets e smartphones.

Palavras-chave: Gestão da Armazenagem; TI aplicada à armazenagem; WMS. 


\begin{abstract}
SORIANO, F. S. Storage Management: analysis of the WMS system management. 2013. 110 f. Master Degree Thesis - Faculdade de Economia, Administração e Contabilidade de Ribeirão Preto, Universidade de São Paulo, Ribeirão Preto, 2013.

This dissertation aimed analyze the warehouse management system (WMS) influence on the studied companies, from the literature research about the established theme and the content analysis of the informations derived from semistructered interviews performed in a multi case study surrounding two enterprises that develop the WMS software, and three organizations that are users of it. Thereby, was possible identify and analyze the strengths and weaknesses of the system, as well the features currently offered to the market. After the analysis of this informations, it can be conclude that the key factors for the success of the implementation are the top management support, employees previous training, good mapping and formalization of user company's process, as the execution of a registration assertive products and addresses. Among the benefits arising the system adoption, besides those mentioned on the literature, was identified the occur of a greater satisfaction and motivation of the operational team, due to the work rotine change to a more organized way. Finally, as the trends of WMS improvement, was related: the integration of the system with the RFID technology, development of betters management reports and the link between the tool the mobility, making its use for tablets and smartphones.
\end{abstract}

Key-words: Warehouse Management TI applied to storage; WMS. 


\section{LISTA DE ABREVIATURAS E SIGLAS}

$\begin{array}{ll}\text { CD } & \text { Centro de Distribuição } \\ \text { CRM } & \text { Customer Relationship Management } \\ \text { EDI } & \text { Eletronic Data Interchange } \\ \text { ERP } & \text { Enterprise Resource Planning } \\ \text { FEFO } & \text { First Expire, First Out } \\ \text { FIFO } & \text { First in, First Out } \\ \text { IBGE } & \text { Instituto Brasileiro de Geografia e Estatística } \\ \text { JIT } & \text { Just in time } \\ \text { MDO } & \text { Mão-de-obra } \\ \text { NF } & \text { Nota Fiscal } \\ \text { PIB } & \text { Produto Interno Bruto } \\ \text { RFID } & \text { Radio-Frequency Identification } \\ \text { SCM } & \text { Supply Chain Management } \\ \text { SI } & \text { Sistema de informação } \\ \text { SKU } & \text { Stock Keeping Units } \\ \text { TI } & \text { Tecnologia da Informação } \\ \text { TMS } & \text { Transportation Management System } \\ \text { WIS } & \text { Warehouse Information System } \\ \text { WMS } & \text { Warehouse Management System }\end{array}$




\section{LISTA DE FIGURAS}

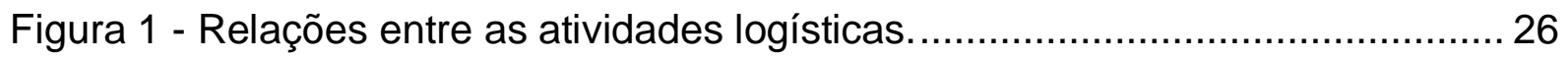

Figura 2 - Logística Integrada................................................................... 27

Figura 3 - Processo de armazenagem......................................................... 31

Figura 4 - Sistemas de informação na armazenagem. ……................................. 36

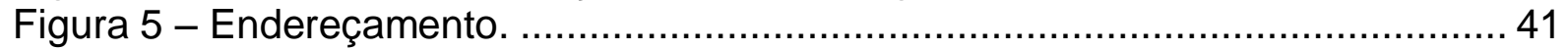

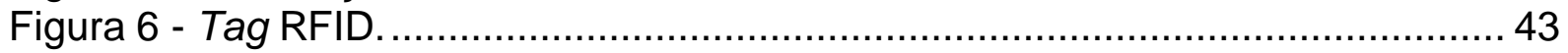

Figura 7 - Coletores de código de barras......................................................... 43

Figura 8 - Processo de captação do sinal de rádio frequência............................... 44

Figura 9 - Fases de implementação do WMS.................................................. 49

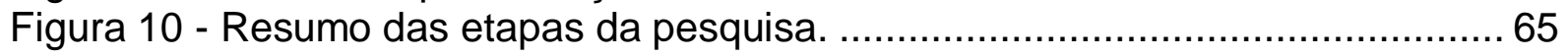

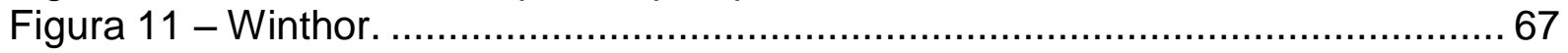

Figura 12 - Winthor, Tela de separação de produtos.......................................... 71

Figura 13 - Tela do relatório de produtividade do Atacado Y................................ 85

Figura 14 - Tela do relatório da distribuição de horas utilizadas do Atacado Y. ....... 86

Figura 15 - Acuracidade de estoque do Atacado Y pós-implantação do WMS......... 87

Figura 16 - Resumo acuracidade de estoque 2012 .............................................. 89

Figura 17 - Relatório de divergências de estoque. ............................................. 90 


\section{LISTA DE QUADROS}

Quadro 1 - Funcionalidades do WMS segundo a literatura..................................46

Quadro 2 - Funcionalidades do WMS consolidadas...........................................48

Quadro 3 - Resumo das variáveis analisadas nos usuários do WMS. ......................55

Quadro 4 - Resumo dos procedimentos metodológicos........................................65

Quadro 5 - Resumo das funcionalidades do WMS PC Sistemas. ............................72

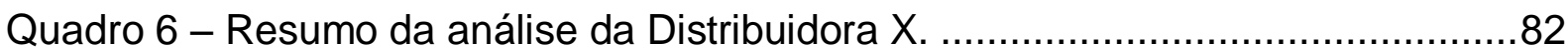

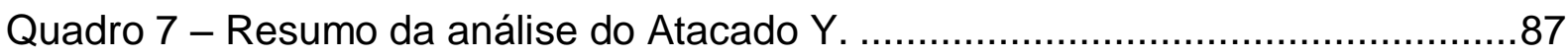

Quadro 8 - Resumo da análise da Cia de Bebidas Ipiranga...................................91

Quadro 9 - Resumo das funcionalidades do WMS (Sythex e PC Sistemas)............93

Quadro 10- Resumo da análise dos desenvolvedores do software WMS................94

Quadro 11 - Resumo da análise das empresas usuárias do WMS. ..........................97 


\section{LISTA DE TABELAS}

Tabela 1 - Composição de custos e margem de uma empresa industrial típica....... 25 


\section{SUMÁRIO}

1 INTRODUÇÃO

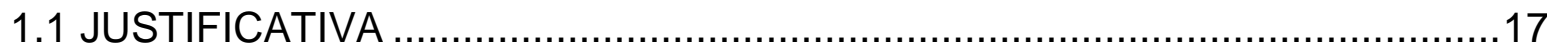

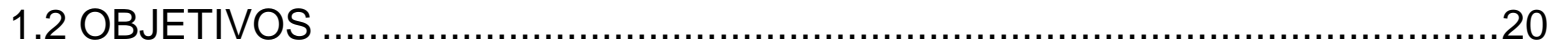

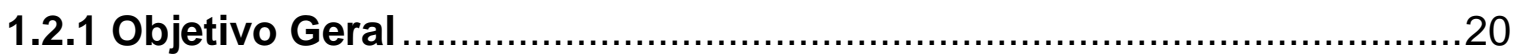

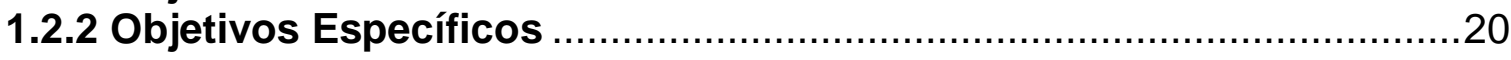

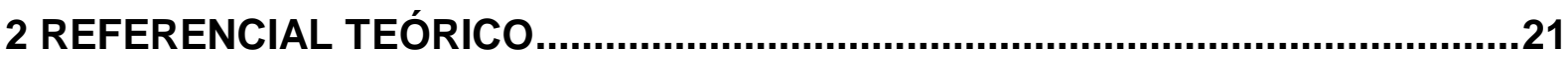

2.1 GERENCIAMENTO DA CADEIA DE SUPRIMENTOS (SCM) ......................21

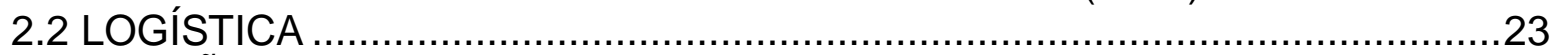

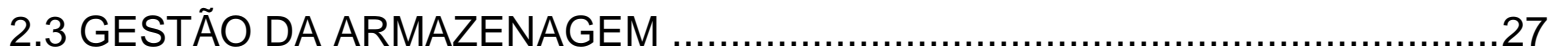

2.3.1 O conceito de gestão da armazenagem …….................................29

2.3.2 Atividades da gestão da armazenagem ............................................

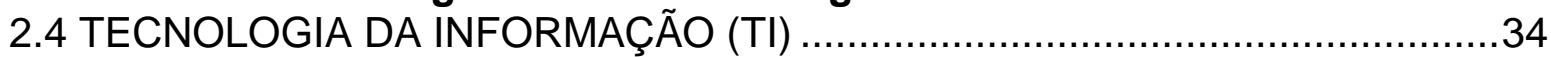

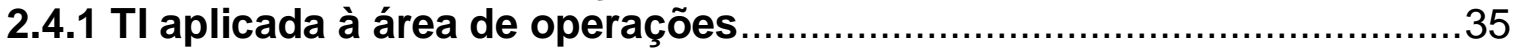

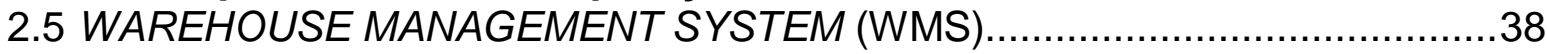

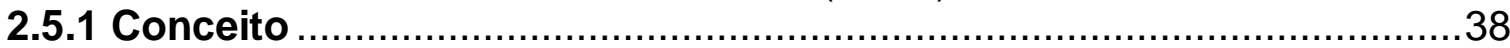

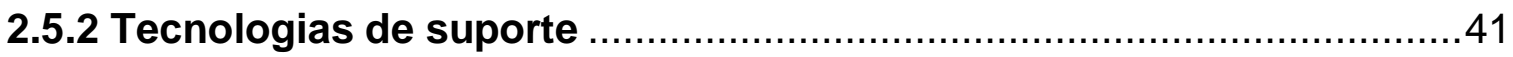

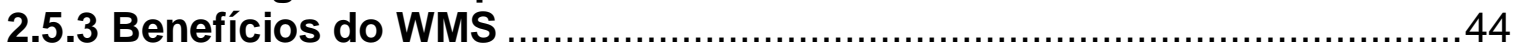

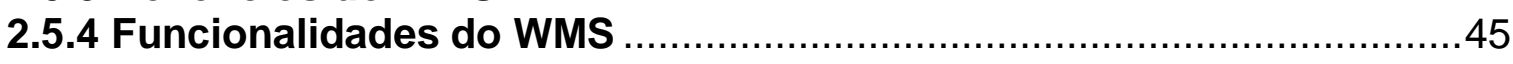

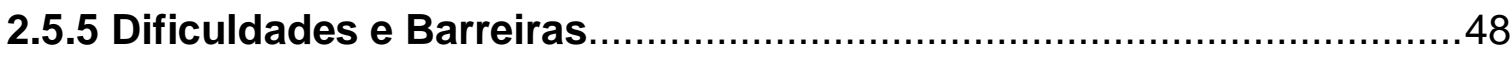

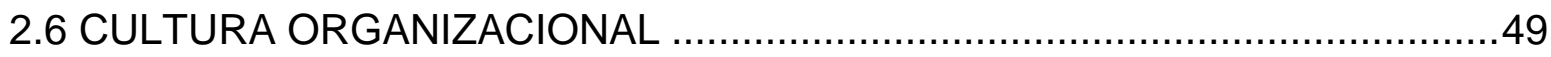

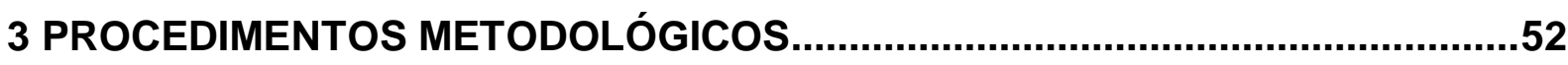

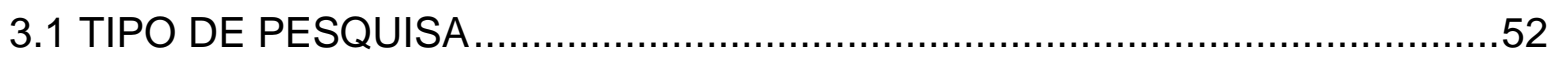

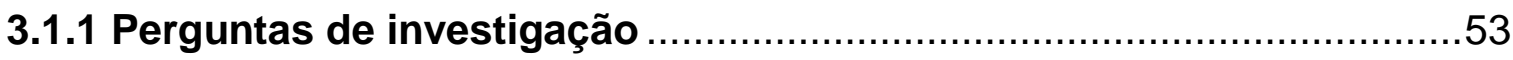

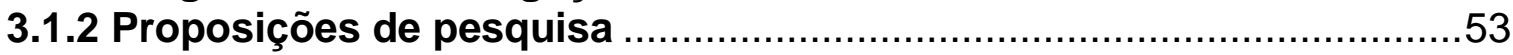

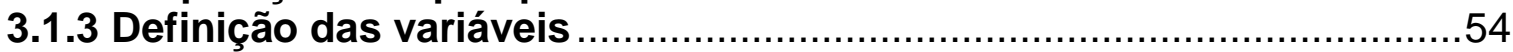

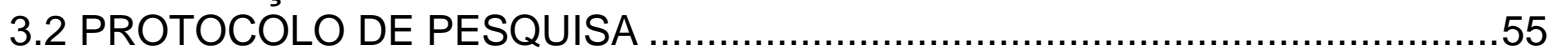

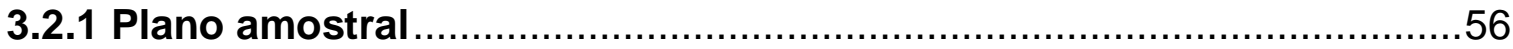

3.2.2 Pessoas-chave para entrevistas ...............................................56

3.2.3 Técnicas e instrumentos de coleta de dados .................................57

3.2.4 Técnicas e procedimentos para análise de dados .............................57

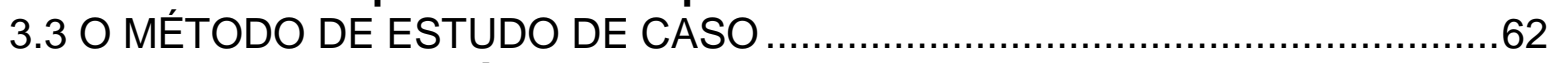

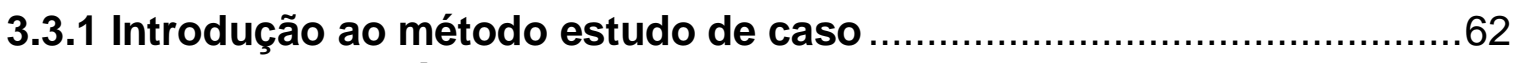

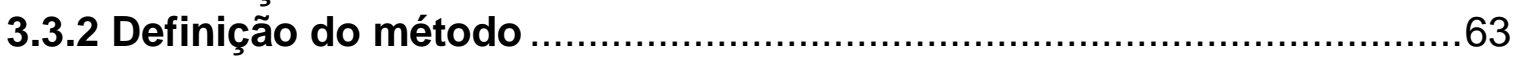

3.3.3 Críticas em relação ao método estudo de caso ................................63

3.3.4 Critérios para avaliação da qualidade dos projetos de pesquisa ........64

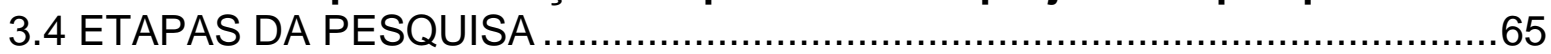

3.5 RESUMO DOS PROCEDIMENTOS METODOLÓGICOS ….........................65

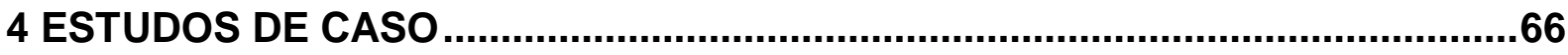

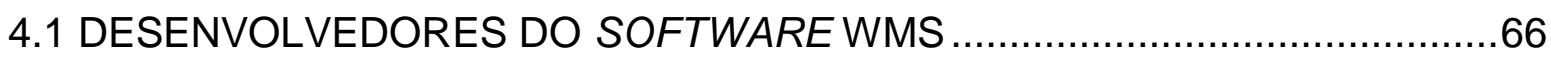

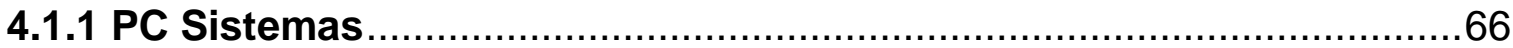

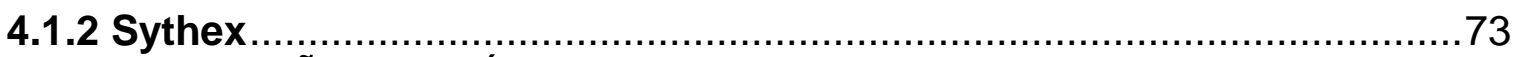

4.2 ORGANIZAÇÕES USUÁRIAS DO SISTEMA WMS .................................77

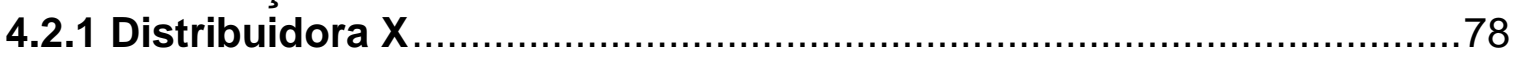


4.2.2 Atacado $Y$

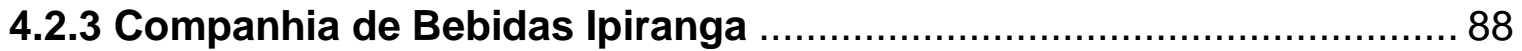

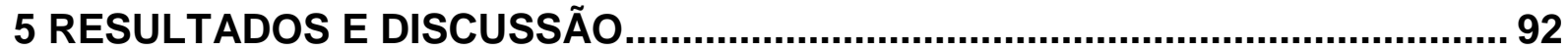

5.1 ANÁLISE DOS DESENVOLVEDORES DO SOFTWARE WMS ..................... 92

5.2 ANÁLISE DAS EMPRESAS USUÁRIAS DO WMS ….................................. 95

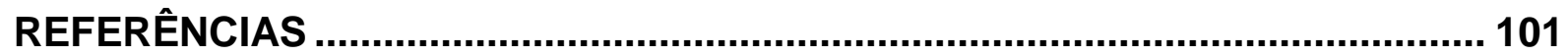

APÊNDICE A - ROTEIRO DE ENTREVISTA SEMIESTRUTURADA PARA OS DESENVOLVEDORES DO SOFTWARE WMS ................................ 108

APÊNDICE B - ROTEIRO DE ENTREVISTA SEMIESTRUTURADA PARA ORGANIZAÇÕES USUÁRIAS DO WMS ............................................109 


\section{INTRODUÇÃO}

A mudança é um fator que vem atuando permanentemente no mercado de trabalho e se tornando parte da rotina das grandes empresas. Segundo Meda (2009), as organizações se encontram em um processo de mutação contínua em busca de um diferencial que gere vantagem competitiva para que elas possam se destacar em meio aos concorrentes.

Em virtude da mudança de comportamento, os consumidores apresentam novos anseios e se mostram cada vez mais exigentes, caracterizando um cenário que engloba "rápidas variações de demanda, menores pedidos realizados via internet, prazos de entrega menores, elevada competição e alta exigência por melhores níveis de serviço" (ROODBERGEN; VIS, 2009, p. 361).

Tais cobranças se refletem em pressão por maior eficiência e eficácia operacional. Martins e Alt (2006) comentam que atender aos clientes na hora certa, com a quantidade adequada e requerida tem sido o objetivo da maioria das empresas. Além disso, os clientes têm demonstrado pouca ou nenhuma tolerância a erros e estão mais exigentes no tocante à qualidade, rapidez na entrega, confiabilidade e ao preço.

A logística, por atuar sobre essas variáveis, tem se tornado um fator relevante para que as organizações consigam atender o cliente de forma eficiente, correspondendo às suas expectativas (BOWERSOX; CLOSS; COOPER, 2007).

Corroborando com essa ideia, Gu, Goetschalckx e McGinnis (2007, p. 1) afirmam que a "competição existente no mercado gera a necessidade de uma contínua melhoria no planejamento e operacionalização das áreas de produção e operação".

Outra questão complexa que pressiona a otimização da área de operações é a busca pelo menor custo logístico possível através da determinação do nível ideal dos estoques, bem como de sua localização, a fim de minimizar o custo de transporte e proporcionar um melhor nível de serviço ao cliente (KUTANOGLU; LOHIYA, 2007).

Um fator que colabora significativamente para tal redução dos custos é a execução de uma gestão da armazenagem eficiente (YAO; DRESNER, 2008). Isto abarca a otimização dos recursos envolvidos e o compartilhamento de informações referentes ao estoque com fornecedores e clientes, possibilitando, desta forma, a 
adequação e redução dos estoques para as empresas pertencentes à mesma cadeia de suprimentos.

Esse panorama faz com que as estratégias clássicas de gestão de estoque não sejam mais aplicadas por diversas organizações (MADADI; KURZ; ASHAYERI, 2009). Faz-se necessária então a busca por novas estratégias de gestão da armazenagem que sejam aplicáveis e gerem resultados não a uma organização isoladamente, mas à cadeia de suprimentos a qual ela pertence, de forma a manter baixos níveis de estoque e garantir o cumprimento dos prazos de entrega estabelecidos.

Neste sentido, o foco da presente pesquisa faz referência à gestão da armazenagem que, segundo Chen, Langevin e Riopel (2011) mostra-se como um elemento fundamental em qualquer cadeia de suprimentos.

\subsection{JUSTIFICATIVA}

As decisões tomadas no decorrer dos governos políticos quanto à estrutura logística nacional tiveram foco sobre o modal rodoviário, o qual obteve um maior montante de investimentos. Tal contexto gerou uma forte dificuldade quanto à transição para um panorama ideal em que o escoamento da produção fosse melhor distribuído na matriz de transportes (entre os modais rodoviário, ferroviário, hidroviário e aéreo). Tamanha morosidade é decorrente do alto investimento necessário em infraestrutura e ao próprio tempo necessário para as realizações de obras que permitam essa transição (MAIA JUNIOR, 2012).

Além destas questões, Madadi, Kurz e Ashayeri (2009) salientam que outros fatores que têm contribuído para o aumento do custo de transporte são o crescente custo do combustível, o custo de manutenção dos veículos e, por fim, os congestionamentos nas estradas e centros urbanos.

Com a dificuldade em se diminuir os custos referentes ao transporte, uma alternativa é a busca pela redução dos custos logísticos internos das organizações. Isso fez com que a visão dos responsáveis pela área de operações se alterasse significativamente; eles passaram a compreender que "ter uma operação de armazenagem eficiente é crucial para a competitividade não somente da empresa, mas da cadeia de suprimentos à qual ela pertence" (ANG; LIM; SIM, 2012, p. 2114). 
Além da questão histórica envolvendo a matriz de transportes, outro fator que contribui de forma relevante para o aumento da importância da gestão da armazenagem é a mudança que vem ocorrendo na dinâmica do mercado e nas exigências dos consumidores. Multiplicaram-se as quantidades de produtos disponíveis no mercado, embalagens novas, tamanhos, sabores e configurações diferentes dos produtos, além de prazos de entrega e de pagamento mais atrativos que surgiram para atender de forma mais precisa e eficiente a necessidade do consumidor final.

Sobre esse cenário, Alves (2000, p. 156) comenta que:

No ambiente competitivo atual, empresas vêm trabalhando com lotes menores, maior frequência dos pedidos e a necessidade de menores prazos de entrega, fatores estes que causam aumentos de custos logísticos, obrigando os responsáveis pelos armazéns e CD a buscar soluções de processos que aumentem a produtividade do pessoal e dos equipamentos do depósito.

Dessa forma, para Gamberini et al. (2008, p. 37), a gestão da armazenagem se mostra como "uma questão fundamental para a satisfação das expectativas do cliente", bem como obtenção de vantagem competitiva em relação ao mercado. Baker e Canessa (2009) também sustentam o mesmo ponto de vista ao afirmarem que realizar uma boa gestão das atividades inerentes à armazenagem é um fator crítico para que as organizações tenham condições de proporcionar um alto nível de serviço no atendimento aos consumidores.

Tal melhoria da gestão da armazenagem pode ocorrer de diversas formas: por meio de treinamento dos colaboradores, pesquisa de melhores práticas existentes no mercado, contratação de gestores mais competentes, remodelagem do processo de armazenagem, troca de equipamentos, adequação das estruturas de armazenagem e do layout utilizado ou ainda uma maior automação do processo. Entretanto, Bowersox, Closs e Cooper (2007) comentam que a armazenagem exige mais do que simples procedimentos automatizados, necessita de sistemas de informação que possam tomar decisões rápidas e inteligentes.

Em contraste com a importância do atendimento a essa necessidade das organizações, Banzato et al. (2010, p. 195) afirmam que "[...] ainda há muito desconhecimento sobre as possíveis alternativas de soluções oferecidas pelo mercado, bem como de suas funcionalidades e características específicas". 
Devido a esta falta de conhecimento por parte das próprias empresas, fica evidente a importância da utilização de uma solução completa que trate não somente de mudanças estruturais ou processuais, porém algo que efetivamente gere um diferencial competitivo. Dentre as possibilidades existentes, o presente trabalho foca em um sistema de gestão da armazenagem denominado WMS (Warehouse Management System).

O WMS é um sistema que visa propiciar a melhor utilização dos recursos inerentes à área de armazenagem, bem como agilizar as atividades operacionais envolvidas, reduzindo desta forma o custo operacional (FLEURY; WANKE; FIGUEIREDO, 2000).

Apesar de se mostrar como uma forma de gestão eficiente, Banzato et al. (2010, p. 188) explicam que:

\begin{abstract}
Muitas empresas têm dificuldades de identificar todos os benefícios de uma solução WMS, muitas vezes por não conhecer todas as características e funcionalidades da solução, bem como não conhecer a realidade do seu processo atual de armazenagem.
\end{abstract}

Um dos fatores que justifica essa situação é que ao longo dos anos houve o aprimoramento dos processos logísticos e o desenvolvimento das necessidades do mercado. Inovações importantes como o desenvolvimento da tecnologia de código de barras, RFID (Radio Frequency Identification - Identificação por Rádio Frequência) ou ainda o conceito de Gestão da Cadeia de Suprimentos (SCM Supply Chain Management) forçaram o desenvolvimento de novas funcionalidades e novos benefícios para que o WMS suportasse tal evolução.

Além desta questão, é importante ressaltar que, segundo Banzato et al. (2010, p. 194), "o WMS é [...] quase uma novidade absoluta para muitas empresas que atualmente pretendem adotá-lo, o conhecimento existente na empresa sobre essa solução é muito reduzido."

Por existir essa deficiência no conhecimento e entendimento dos benefícios e funcionalidades do WMS, Banzato et al. (2010, p. 174) ainda afirmam que:

É importante que se faça uma ampla e abrangente análise das necessidades de operacionalidade e funcionalidade para o futuro do sistema [...] assim sendo, quanto mais se conhece sobre WMS, mais facilidade as empresas têm de fazer uma adequada análise de custo vs. benefício. 


\subsection{OBJETIVOS}

\subsubsection{Objetivo Geral}

Realizar um estudo sobre o sistema WMS em um grupo de desenvolvedores e em empresas usuárias.

\subsubsection{Objetivos Específicos}

No intuito de atingir o objetivo geral foram definidos quatro objetivos específicos, através dos quais se pode obter as informações necessárias à presente pesquisa.

- Realizar estudos de caso com usuários e desenvolvedores do sistema WMS;

- Identificar as funcionalidades atualmente oferecidas ao mercado e as tendências para o aprimoramento da ferramenta, segundo as empresas participantes da pesquisa;

- Identificar os benefícios e dificuldades perceptíveis provenientes da adoção desse modelo de gestão. 


\section{REFERENCIAL TEÓRICO}

Para a realização deste trabalho acadêmico, mais especificamente do seu referencial teórico, é importante que sejam explicadas as bases teóricas necessárias para fundamentá-lo. Nesse sentido, foram definidas as seguintes bases teóricas: (1) Gerenciamento da Cadeia de Suprimentos; (2) Logística; (3) Gestão da Armazenagem; (4) Tecnologia da Informação; (5) WMS; (6) Cultura Organizacional.

Feitas tais considerações, as seções a seguir versam sobre os principais conceitos teóricos abordados nesta dissertação.

\subsection{GERENCIAMENTO DA CADEIA DE SUPRIMENTOS (SCM)}

Com a crescente competitividade inerente ao mercado atual, os consumidores tendem a almejar um processamento cada vez mais ágil de seus pedidos, envolvendo entrega rápida e um alto índice de disponibilidade do produto. Em resposta a esta mudança de comportamento, as empresas têm buscado otimizar as suas operações logísticas no intuito de melhor atender ao cliente (BALLOU, 2006).

As organizações perceberam a necessidade de trabalhar com maior agilidade e precisão não somente nas suas operações internas, mas também na cadeia de suprimentos. A partir deste entendimento, compreende-se que a competição passa a ser entre cadeias de suprimentos e não mais entre as empresas individualmente (TRKMAN et al. 2010).

Explicando este conceito, Ballou (2006, p. 29) comenta que a cadeia de suprimentos

É um conjunto de atividades funcionais (transportes, controle de estoques, etc.) que se repetem inúmeras vezes ao longo do canal pelo qual matérias-primas vão sendo convertidas em produtos acabados, aos quais se agrega valor ao consumidor.

O fluxo de operações deste conjunto de atividades inicia-se no momento em que o cliente final realiza a sua compra. A partir deste instante, o varejo faz uma nova solicitação de compra a fim de repor o produto vendido, na sequência o atacado recebe essa informação, repõe o varejo e executa o mesmo procedimento. 
E assim subsequentemente envolvendo também empresas de transporte, indústrias e fornecedores de matéria-prima.

Em suma, a aquisição do cliente é a informação que ativa o fluxo de materiais e informações na cadeia de suprimentos, sendo justamente sobre este fluxo que o conceito de gestão da cadeia de suprimentos (SCM - Supply Chain Management) atua.

Conforme explicado por Ballou (2006, p. 27), o SCM "é um termo surgido mais recentemente e que capta a essência da logística integrada e inclusive ultrapassa". O gerenciamento da cadeia de suprimentos destaca as interações logísticas que ocorrem entre as funções de marketing, logística e produção no âmbito de uma empresa e entre empresas diferentes que compõe o canal de fluxo de produtos até o cliente final.

Portanto, pode-se dizer que "o SCM ajuda as empresas a gerir o fluxo de informação, dinheiro, e produtos além das fronteiras físicas da organização" (SHIH et al., 2012, p. 70).

O conceito de SCM tem por objetivo, segundo Vijayasarathy (2010, p. 364), "facilitar a eficiente e eficaz movimentação do fluxo de produtos, serviços, financeiro e/ou informação desde a fonte até o consumidor final". Dessa forma, fomentando a motivação do cliente em adquirir determinado produto ao perceber o valor agregado oferecido por ele, assim fidelizando-o.

Sendo assim, compreende-se que integrar o fluxo de informação na cadeia de suprimentos se tornou uma questão crítica para o aprimoramento do desempenho das organizações (ZHOU; BENTON JR, 2007).

Nesta relação entre diversas empresas, um dos desafios é justamente a integração de suas operações. Para superar essa dificuldade, as empresas envolvidas devem estar engajadas na melhoria das operações através de um planejamento, execução e monitoramento conjuntos. Essa integração entre diversas organizações pertencentes a uma cadeia de suprimentos é denominada sincronização da cadeia de suprimentos (BOWESOX; CLOSS; COOPER, 2007).

Para atingir tal grau de interação, a tecnologia da informação mostra-se como um fator preponderante. Segundo Sanders e Premus (2002), as empresas que utilizam tecnologia mais desenvolvida do que os concorrentes têm condições de integrar de forma mais eficiente as operações logísticas da cadeia de suprimentos, 
consequentemente obtendo maiores benefícios, como redução de custo e tempo de execução das atividades.

Quando as empresas envolvidas na cadeia conseguem fazer a sincronização da mesma, os objetivos do SCM passam a ser atingidos. Martins e Alt (2006) afirmam que o benefício proveniente desta prática reside em coordenar o fluxo de materiais e informações entre os parceiros da cadeia a fim de satisfazer rapidamente o cliente, minimizar os custos financeiros (menor uso de capital de giro e menor nível de estoques) e os operacionais (redução de desperdícios), tornando o processo mais eficiente e eficaz.

A redução de custos através da sincronização da cadeia de suprimentos é um dos fatores que fomenta a ânsia das organizações em conseguir trabalhar com 0 SCM. Uma das áreas onde há um forte potencial para redução destes custos é a gestão da armazenagem, visto que, atualmente, nos ambientes empresariais a pressão para a redução dos níveis de estoque é uma constante, em virtude dos custos inerentes à sua manutenção. Por estas razões, Chien-ming et al. (2010, p. 70) afirmam que "a gestão da armazenagem mostra-se como sendo um fator crucial no atual mercado".

Com isso, há uma crescente ambição pelo aperfeiçoamento no controle dos níveis de estoque nas cadeias de suprimentos, pois a baixa qualidade das informações relativas aos saldos de estoque pode ocasionar atrasos nos fornecimentos, paradas de produção, entre outros problemas (DROHOMERETSKI; FAVARETTO, 2010).

Esse fato estimula a pesquisa e o estudo de alternativas de modelos de gestão e/ou tecnologias que auxiliem na redução, ou ainda, na otimização dos custos operacionais na armazenagem. Para compreender melhor essa questão a próxima seção aborda o conceito de logística.

\subsection{LOGÍSTICA}

A logística é uma atividade que ocorre há séculos - as antigas civilizações já tinham a necessidade de transporte e armazenagem das mercadorias comercializadas. Assim, o conceito de logística foi criado em referência às atividades operacionais que possibilitam o atendimento à demanda do cliente. Martins e Alt (2006) explicam que ela foi aplicada primeiramente no âmbito militar, fazendo 
referência à alocação dos recursos certos no local certo, na hora certa, com o objetivo de vencer batalhas.

Trazendo esse conceito para o contexto empresarial, Ballou (1993, p. 17) afirma que:

A logística empresarial estuda como a administração pode prover melhor nível de rentabilidade nos serviços de distribuição aos clientes e consumidores, através de planejamento, organização e controle efetivos para as atividades de movimentação e armazenagem que visam facilitar o fluxo de produtos.

Complementando essa ideia, Bowersox, Closs e Cooper (2007, p. 24) comentam que a logística envolve diversas atividades, entre elas "a gestão do processamento de pedidos, os estoques, os transportes e a combinação de armazenamento, manuseio de materiais e embalagem".

Todas essas atividades foram se desenvolvendo com o passar do tempo, tornando-se mais complexas e precisas em seus controles e execuções. Entretanto, esse desenvolvimento ocorreu tardiamente em nosso país, segundo Fleury, Wanke e Figueiredo (2000, p. 19), "até meados da década de 90, a logística era o elo perdido da modernização empresarial no Brasil”. Nesse período, ocorreram intensas mudanças em termos de práticas empresariais, melhoria da eficiência e qualidade dos processos e, por fim, na disponibilidade da infraestrutura.

Os autores explicam que o motivo de tamanha mudança ocorrer nesse período se deve a algumas características históricas como, por exemplo, o processo de abertura comercial e a estabilização econômica proporcionada pelo Plano Real. Nessa época, o conceito de logística não era plenamente compreendido, de acordo com Martins e Alt (2006, p. 325) "até poucos anos atrás, o termo logística continuava associado a transportes, depósitos regionais e atividades ligadas a vendas".

Confirmando a existência dessa situação, Ballou (1993, p. 18) salienta que:

[...] a administração de empresas nem sempre se preocupou em focalizar o controle e a coordenação coletiva de todas as atividades logísticas. Somente nos últimos anos é que ganhos substanciais nos custos foram conseguidos, graças à coordenação cuidadosa destas atividades. 
A carência de eficiência e eficácia na questão logística passou a ser melhor percebida conforme o mercado foi se desenvolvendo e se tornando mais competitivo. Nesse contexto, Pereira et al. (2010, p. 150) afirmam que:

O desenvolvimento da logística empresarial tem apresentado enormes proporções nos últimos anos, por ser fator essencial para a competitividade das empresas e existem diversos fatores que aceleram este desenvolvimento. Entre eles: (1) Pressão por mais giro de estoque; (2) Redução de estoques; (3) Atendimento a mercados distantes; (4) Novas tecnologias; (5) Curto ciclo de vida dos produtos.

Tal cenário demonstra uma maior agilidade e confiabilidade demandada por parte dos consumidores, o que gera nas empresas a necessidade de serem mais eficientes em diversos aspectos, o que inclui a questão operacional.

A redução de custos foi um importante fator incentivador para essa mudança de visão sobre a logística. Afinal, aumentar a receita e reduzir custos é um objetivo fundamental, almejado por todas as empresas que visam o lucro. Fazendo uma análise sobre o custo logístico brasileiro, Fleury, Wanke e Figueiredo (2000, p. 30) afirmam que "[...] embora não existam levantamentos específicos, estima-se que no Brasil os gastos com as atividades logísticas correspondam a cerca de $17 \%$ do PIB".

Com base nessa informação, pode-se fazer uma comparação deste percentual com o Produto Interno Bruto (PIB) brasileiro em 2011. Segundo o Instituto Brasileiro de Geografia e Estatística (IBGE, 2012), o PIB em 2012 foi de 4,143 trilhões de reais, calculando-se o percentual de $17 \%$, o valor correspondente às atividades logísticas chega à soma de 704,3 bilhões de reais, número significante que ressalta a relevância do setor.

A logística também representa um valor importante dentro do preço de uma mercadoria produzida pela indústria, conforme mostrado pela Tabela 1.

Tabela 1 - Composição de custos e margem de uma empresa industrial típica

\begin{tabular}{lc}
\hline \multicolumn{1}{c}{ Dados da Operação } & Percentuais \\
\hline Margem de lucro & $8 \%$ \\
Custos logísticos & $19 \%$ \\
Custos de marketing & $20 \%$ \\
Custos de produção & $53 \%$ \\
\hline
\end{tabular}

Fonte: Adaptado de Fleury, Wanke e Figueiredo (2000).

Com base em tais comparações, observa-se a real importância da logística, tanto para a economia nacional, como para as organizações. Tamanha relevância 
contribuiu para a mudança de visão em relação à atividade, além do desenvolvimento de novos estudos e da própria prática existente no mercado.

Corroborando com esse raciocínio, Bowersox e Closs (2007) afirmam que o principal objetivo da logística é tornar os produtos e serviços disponíveis onde são necessários, no momento em que são desejados. Para que esse objetivo seja atingido é necessário compreender quais são as operações que a logística executa, onde elas começam e onde terminam.

Explicando essas questões, Ballou (1993, p. 24) comenta que a logística "trata de todas as atividades de movimentação e armazenagem, que facilitam o fluxo de produtos desde o ponto de aquisição de matérias-primas até o ponto de consumo final". O autor ainda argumenta que este conceito trabalha com três principais áreas: transportes, manutenção de estoques e processamento de pedidos. A sua integração é mostrada pela Figura 1.

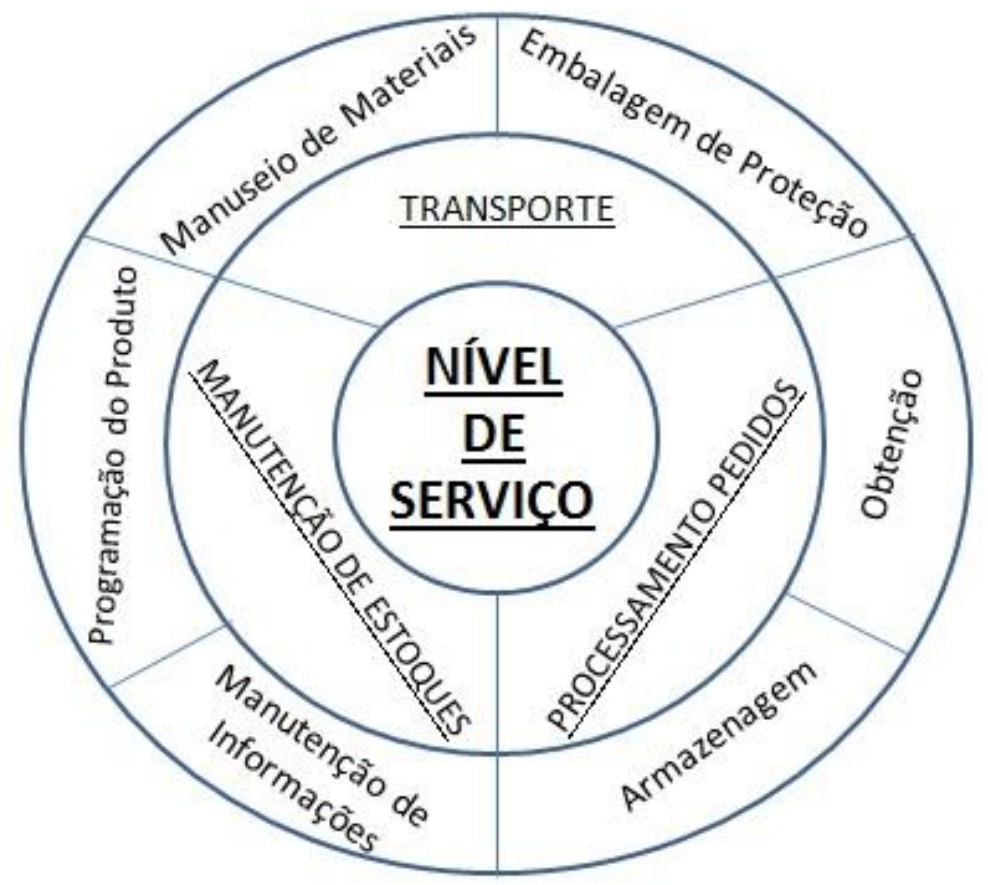

Figura 1 - Relações entre as atividades logísticas.

Fonte: Adaptado de Ballou (1993).

Além da integração entre as operações internas, também existe uma interrelação com outras organizações (MARTINS; ALT, 2006), conforme ilustra a Figura 2. 


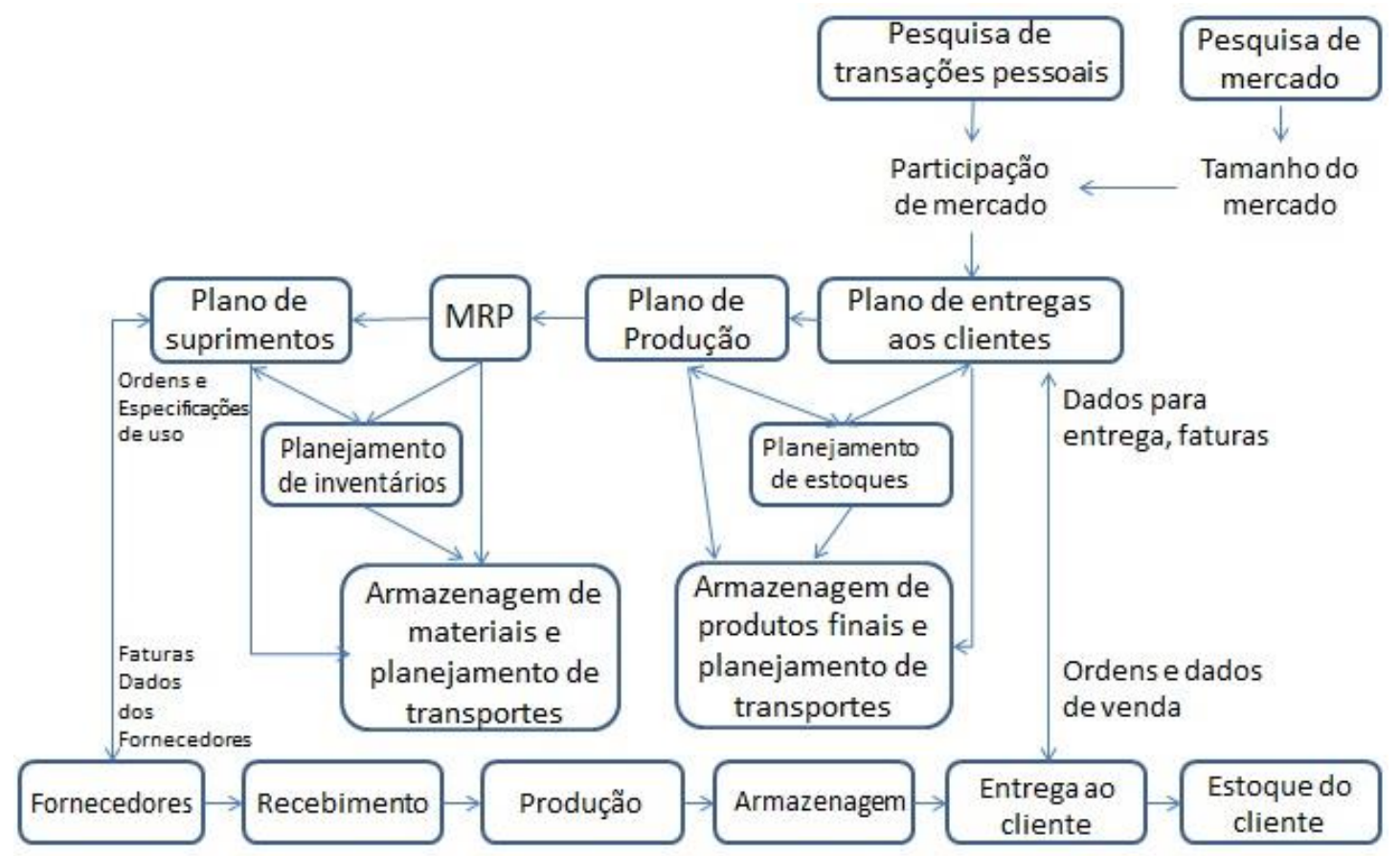

Figura 2 - Logística Integrada.

Fonte: Adaptado de Martins e Alt (2007).

Além da relação com fornecedores e clientes, existem ainda outras instituições que influenciam e são influenciadas por essas operações, como, por exemplo, transportadoras e empresas prestadoras de serviço. Focando na atividade da logística, a seção a seguir versa sobre a gestão da armazenagem.

\subsection{GESTÃO DA ARMAZENAGEM}

A gestão da armazenagem não é um conceito inerente apenas aos dias de hoje, as civilizações antigas já estocavam e armazenavam mantimentos e água para sobreviver aos tempos de escassez. Com o passar do tempo, essa prática foi se modernizando até chegar ao patamar atual em que a gestão da armazenagem se traduz em um fator que pode gerar valor para o cliente final (BALLOU, 1993).

Para compreender como isto ocorre é conveniente que primeiramente seja entendido o conceito e o papel dos estoques. Segundo Martins e Alt (2006), os estoques são um elemento regulador, tanto do fluxo de produção como do fluxo de vendas. Eles são um recurso produtivo que no final da cadeia de suprimentos cria valor para o cliente, pois a administração eficiente e eficaz dos mesmos propicia a oportunidade de atender com maior facilidade e prontidão a demanda, no momento e na quantidade desejada. 
É importante frisar que a abordagem aqui adotada não considera apenas a operação interna das organizações. Atualmente, com o advento da tecnologia e o forte fluxo de informações e mercadorias, as ações ocorridas em cada organização geram reflexos para outras empresas pertencentes à mesma cadeia de suprimentos.

Sobre essa relação de influência, Chiang, Lin e Chen (2011) explicam que atualmente os clientes estão menos propensos a manter estoques, já que os pedidos são realizados de forma cada vez mais frequente e solicitando um volume menor de itens, bem como menores prazos de entrega.

Cenário este que força o estoque para trás na cadeia de suprimentos, repassando-o ao fornecedor. Isso ocorre, pois o varejo percebeu que é mais interessante utilizar o espaço disponível para comercializar do que para estocar, desta forma, aumenta-se a receita, enquanto minimiza-se o custo de armazenagem (RAMOS; MELO, 2003).

Essa tendência do mercado em trabalhar com níveis de estoque mais baixos leva os clientes a demandarem menores tempos de resposta dos seus fornecedores, além de se mostrarem menos tolerantes a erros. Essa intolerância ocorre, pois, como os clientes trabalham com um baixo nível de estoque, a falha na entrega do pedido provavelmente pode gerar a falta de produto e consequentemente a perda de vendas. Tal condição gera a necessidade de que haja agilidade nos centros de distribuição e armazéns.

Além disso, Ballou (2006) destaca o visível aumento do número de itens mantidos em estoque - stock keeping units (SKUs), produzidos pela indústria, no intuito de atingir determinados nichos de mercado e necessidades específicas. Variações nos tamanhos das embalagens de produtos comercializados no varejo aumentam o número de itens a ser controlados, processados e manuseados nos armazéns, o que gera uma diminuição da produtividade, maior necessidade de espaço ou melhor utilização e organização dos recursos disponíveis, além de maiores custos administrativos e operacionais.

Complementarmente, a adoção de novas filosofias de gestão como Just in Time (JIT) e produção enxuta também trazem novos desafios para o sistema de gestão de armazenagem, tais como: controle de inventário mais preciso e menor tempo de resposta (GU, GOETSCHALCKX e MACGINNIS, 2007).

Diante de tais dificuldades, Ballou (2006) afirma que a armazenagem pode contribuir com a organização de quatro formas: (1) redução de custos de transporte 
e produção, (2) coordenar oferta e demanda, (3) assessorar no processo de produção e (4) colaborar no processo de comercialização.

Com frequência a localização do fornecedor está geograficamente distante do consumidor final. Sendo assim, a existência de estoque apenas no local de fabricação pode gerar um alto tempo de espera até que o pedido do cliente seja entregue, ocasionando insatisfação. Da mesma forma, pedidos realizados em localidades distantes do centro produtor exigem que uma grande distância seja percorrida até a entrega e, quanto maior a distância, maior o custo de transporte.

Portanto, caso sejam disponibilizados armazéns estrategicamente posicionados, próximo às maiores regiões de consumo, é possível melhorar ambas as situações - o nível de serviço é favorecido, já que o produto demora menos tempo até chegar ao cliente final e o custo de transporte é minimizado, já que a distância a ser percorrida pelos veículos é reduzida.

\subsubsection{O conceito de gestão da armazenagem}

A armazenagem tem passado por profundas transformações nos últimos anos, provenientes de fatores como a adoção de novos sistemas de informação, sistemas automáticos de movimentação e separação de pedidos, novos equipamentos e estruturas de armazenagem. Definindo o conceito, Rodrigues (2011, p. 36) afirma que:

\footnotetext{
Pode-se definir armazenagem como a gestão econômica do espaço necessário para manter estoque de mercadorias pertencentes a terceiros. Isso engloba todas as funções de localização, dimensionamento da área, arranjo físico, recuperação do estoque, projetos de docas ou baias de atracação e configuração do armazém.
}

Corroborando com essa definição, Banzato et al. (2010) salientam que a principal função da armazenagem é a administração do espaço e do tempo, ou seja, trata-se da gestão do espaço disponível no armazém, para que seja utilizado de forma organizada e racional, bem como o tempo disponível para a realização das atividades operacionais do armazém. Isso envolve uma clara e eficiente definição dos processos e fluxos de materiais, pessoal e informação. 
$\mathrm{Na}$ operação, além da gestão do espaço e tempo, Ballou (2006) afirma que também são funções da gestão da armazenagem a estocagem dos produtos e o manuseio dos materiais, que envolvem a escolha e manutenção dos equipamentos e estruturas utilizados, do layout adotado e o controle das informações e dos processos relacionados à armazenagem.

Tais funções são realizadas de forma a atingir as metas de desempenho estabelecidas, segundo Viana (2002), a boa utilização do espaço disponível é uma das principais metas da gestão da armazenagem, para tanto, as estruturas de armazenagem verticais apresentam-se como uma boa solução para o melhor aproveitamento do espaço disponível. Outros pontos importantes são o raciocínio lógico para definir a localização dos produtos no estoque, sendo os mais pesados armazenados nos andares inferiores e os mais leves na parte mais alta da estrutura e a alocação dos produtos de maior giro próximos à área de expedição, o que minimiza a distância percorrida na movimentação interna, agilizando o processo de recebimento e expedição.

Trabalhando desta forma, a operação tem condições de reduzir o tempo de procura, movimentação e separação dos itens, o que consequentemente agrega eficiência ao processo (ACCORSI; MANZINI; BORTOLINI, 2012).

Sobre esta gestão econômica do espaço, Koster, Le-Duc e Roodbergen (2007, p. 481) afirmam que as organizações cada vez mais "tentam reduzir custos e melhorar a produtividade em seus armazéns e centros de distribuição". Sendo esse um dos motivos pelos quais a gestão da armazenagem vem sendo observada pelas empresas não apenas como uma área de suporte, mas também como um fator de importância significativa para a competitividade da organização.

O tópico a seguir trata das principais atividades da gestão da armazenagem e procura entender como elas podem contribuir para a geração de vantagem competitiva.

\subsubsection{Atividades da gestão da armazenagem}

Conforme afirmado anteriormente, Ballou (2006) explica que as duas principais funções da armazenagem são a estocagem e movimentação (manuseio) dos produtos, subdivididas da seguinte forma: 
- Estocagem

- Armazenagem dos materiais;

- Consolidação para formação de carga;

- Fracionamento de volumes para transbordo.

- Manutenção

- Carga e descarga;

- Movimentação para estocagem;

- Separação dos pedidos.

Não existe um consenso quanto às exatas denominações das atividades da gestão da armazenagem. Para Martins e Alt (2006), elas se resumem em (1) armazenagem, (2) consolidação de carga e (3) desconsolidação de cargas. Sendo assim, é conveniente adotar uma forma racional para a definição de tais tarefas, como o fluxo da armazenagem ilustrado pela Figura 3.

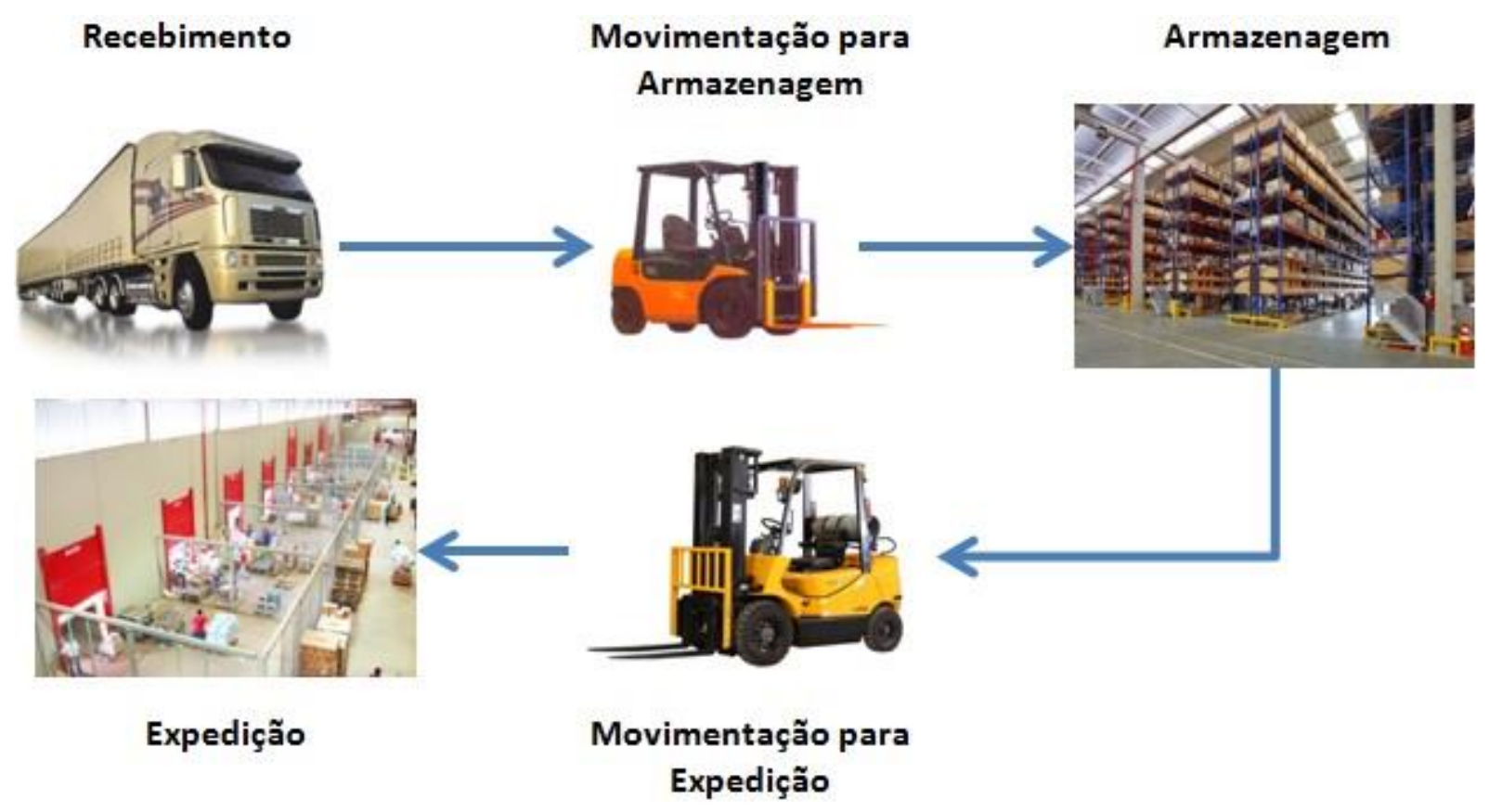

Figura 3 - Processo de armazenagem.

Além das atividades convencionais, Koster, Le-Duc e Roodbergen (2007, p. 482) destacam que "a operação do armazém também envolve a recuperação de produtos e materiais, recolhendo dos consumidores e redistribuindo para outros clientes, empresas de reciclagem ou ainda para os fabricantes", demonstrando que, atualmente, a operação realizada em armazéns é ainda mais complexa. 
Dentro do processo descrito acima, a separação de pedidos (picking) tem sido identificada como a tarefa mais onerosa e de maior uso intensivo da mão-de-obra em praticamente todos os armazéns. Estima-se que aproximadamente $55 \%$ do custo operacional de um armazém são inerentes à separação de pedidos (KOSTER; LEDUC; ROODBERGEN, 2007).

Segundo Yu e Koster (2010), isso ocorre frequentemente porque os colaboradores que realizam a apanha dos itens demandados na ordem de separação dispendem muito tempo procurando os produtos e movimentando-se para segregá-los, acarretando em baixa produtividade operacional.

Com uma representatividade tão relevante, um desempenho abaixo do esperado desta atividade pode gerar um nível de serviço insatisfatório, bem como um alto custo operacional, sendo que este se reflete para toda a cadeia de suprimentos. Exemplos práticos são as avarias ocorridas em virtude do manuseio dos produtos de forma indevida, separação equivocada do produto solicitado (acarretando em devoluções), ou ainda, erros na separação da quantidade solicitada. Todas estas falhas resultam em um custo financeiro desnecessário e prejudicial a qualquer organização.

Visando minimizar tais desperdícios, Sahin e Dallery (2009, p. 108) afirmam que:

Vários estudos empíricos têm analisado a magnitude desse tipo de erro. Dentre as razões para esse problema foram identificadas, erros de reposição, roubo por parte de colaboradores, roubo por parte de clientes, manipulação indevida de mercadoria avariada, falhas de auditoria e registros equivocados (movimentação, vendas, recebimento).

Para que seja possível identificar as razões desses problemas é necessário que haja um controle preciso da operação, que possibilite a obtenção de informações que diagnostiquem quando e onde as falhas ocorrem. Neste contexto, a implantação de um sistema de gerenciamento da armazenagem é uma opção interessante para a resolução desse tipo de problema. Segundo Sahin e Dallery (2009, p. 108):

Um sistema de gerenciamento da armazenagem consiste no acompanhamento contínuo dos tipos e quantidades de produtos através do uso de sistemas de informação como o código de barras ou a identificação por radiofrequência (RFID), usados através de uma avançada base de dados para armazenar e processar essas informações e liberar ordens de compra para os fornecedores conforme a necessidade. 
Além de identificar e minimizar falhas, essa ferramenta visa também estipular os diversos níveis de materiais e produtos que a organização deve manter em estoque, de forma a atender as suas necessidades com o mínimo possível de desperdício. Nesse aspecto, são considerados estoques de matéria-prima, material de manutenção, material de escritório, peças em processo e produtos acabados, dentre outras definições (POZO, 2002).

A decisão acerca das quantidades dos materiais a serem mantidos em estoques está relacionada aos custos associados ao processo produtivo e à estocagem. Dessa forma, o controle de estoque trabalha em função de controlar o investimento realizado em materiais utilizados pela empresa. Para um melhor gerenciamento desse estoque, Pozo (2002) define alguns objetivos do planejamento e controle de estoque:

- Assegurar o suprimento adequado de matéria-prima, materiais auxiliares, peças e insumos de produção;

- Manter o estoque o mais baixo possível, atendendo adequadamente a demanda;

- Identificar e eliminar itens obsoletos e defeituosos em estoque;

- Não permitir falta ou excesso de estoque em relação à demanda;

- Prevenir perdas, danos e extravios;

- Ter uma alta acuracidade de estoque (estoque físico x estoque contábil);

- Manter custos baixos de manutenção de estoque.

Explicando o conceito de acuracidade de estoque, Sahin e Dallery (2009) afirmam que no gerenciamento da armazenagem uma questão importante é a precisão no controle dos produtos, das embalagens e dos itens que fazem parte do estoque.

Saber exatamente o que há fisicamente no armazém através de dados informados pelo sistema é o que define a assertividade do controle realizado. Essa precisão é um indicador da confiabilidade da informação fornecida pelo sistema quanto mais alta a acuracidade de estoque, menor é a discrepância entre o estoque contábil (sistema) e o estoque físico. 
O sucesso no alcance dos objetivos mencionados pode contribuir de forma significativa para uma maior eficiência operacional do processo de armazenagem, bem como para a redução de custos inerentes ao mesmo, melhorando assim o desempenho da operação.

É importante frisar que uma questão relevante para uma maior eficiência operacional é o registro e monitoramento das atividades. Essas informações sendo bem gerenciadas propiciam ao gestor da área embasamento para a tomada de decisões quanto a ações corretivas ou preventivas de possíveis falhas operacionais.

Com tamanha complexidade existente nas operações de armazenagem, Pereira et al. (2010, p. 152) explicam que "manter um fluxo de informações não informatizado é pouco confiável e propenso a erros", o que contribui para a ineficiência das operações de um armazém.

Por esse motivo, o desempenho operacional é diretamente influenciado pela aplicação de novas tecnologias que aprimoram a qualidade dos processos de armazenagem (GU; GOETSCHALCKX; MCGINNIS, 2007).

Com o destaque dado atualmente à aplicação dessas novas tecnologias à gestão da armazenagem, verifica-se a relevância da pesquisa acadêmica acerca desse tema. Sendo assim, a próxima seção discorre sobre a tecnologia da informação.

\subsection{TECNOLOGIA DA INFORMAÇÃO (TI)}

Era comum na rotina das organizações a simples execução do planejamento a fim de atingir as metas estabelecidas. Os percalços que surgiam no dia a dia eram superados e, desde que a meta final fosse atingida, considerava-se este um bom desempenho.

Essa situação não ocorre mais nas empresas que trabalham com foco na melhoria contínua. Segundo Banzato (2005), atualmente o registro, o controle e monitoramento das atividades e dos processos organizacionais são também uma questão importante para as organizações.

Portanto, não é suficiente apenas atingir a meta definida, saber identificar as distorções ocorridas quanto ao planejamento e a quantidade e tipo das falhas que ocorrem nos processos são fontes importantes de informação para que possam ser tomadas ações corretivas e preventivas que minimizem a reincidência de tais problemas. 
Outra questão que tem ressaltado a importância da $\mathrm{TI}$ e suas aplicações é o conceito de gestão da cadeia de suprimentos (SCM). Segundo Rutner, Gibson e Williams (2003), a evolução desse conceito tem demandado que as organizações melhorem o seu controle e fluxo de informação.

Em resumo, o valor da informação tem recebido maior atenção por parte dos gestores e a sua gestão através da tecnologia tem se tornado uma rotina e uma questão relevante para as organizações. A tecnologia da informação ( $\mathrm{TI})$ pode ser utilizada em diversas áreas da organização, entretanto, corroborando com o tema abordado, essa seção enfatiza as aplicações da TI na área de operações.

\subsubsection{TI aplicada à área de operações}

A informação tem se mostrado cada vez mais um fator determinante para o bom gerenciamento das organizações, segundo Tseng, Wu e Nguyen (2011), o seu tratamento e controle adequados podem gerar benefícios significativos que contribuam para um melhor desempenho das empresas.

Salientando essa questão, os autores Sahin e Dallery (2009, p. 108) afirmam que "a competição através da busca de altos níveis de atendimento ao cliente com o mínimo custo tem colocado uma forte ênfase no controle da informação e fluxo de material".

Essa melhoria no gerenciamento das atividades e no controle da informação ocorre através da adoção de softwares que integram os processos organizacionais, proporcionando a minimização de falhas, redução no tempo de execução de diversas atividades e maior precisão nos controles gerenciais. Dessa forma, as empresas que fazem uso de tal aparato tecnológico em suas operações tendem a ser mais competitivas (PEREIRA et al., 2010).

Corroborando com este raciocínio, Alves (2000, p. 154) comenta que:

Cada vez mais as empresas buscam na TI alternativas para facilitar o gerenciamento de suas atividades, visando aumentar o controle e obter informações precisas que possam de fato agilizar a tomada de decisões e, consequentemente, melhorar o nível de serviço prestado. 
A responsabilidade da área de operações é justamente otimizar este nível de serviço prestado ao cliente, sendo que o fator mais crítico para a melhoria do mesmo é a informação. Segundo Pereira et al. (2010, p. 149), é a sua gestão adequada que possibilita a "[...] redução de custos, melhoria da gestão e diferenciação dos níveis de serviço oferecidos pela empresa".

Essa pressão por redução dos custos e otimização operacional ocorreu simultaneamente ao desenvolvimento do mercado e a evolução dos processos logísticos, o que gerou a necessidade de novas tecnologias que tivessem condição de proporcionar uma gestão mais eficiente das operações (KIESMULLER; BROEKMEULEN, 2010). Para otimizar as atividades logísticas, surgiram várias opções de ferramentas que são ilustradas pela Figura 4.

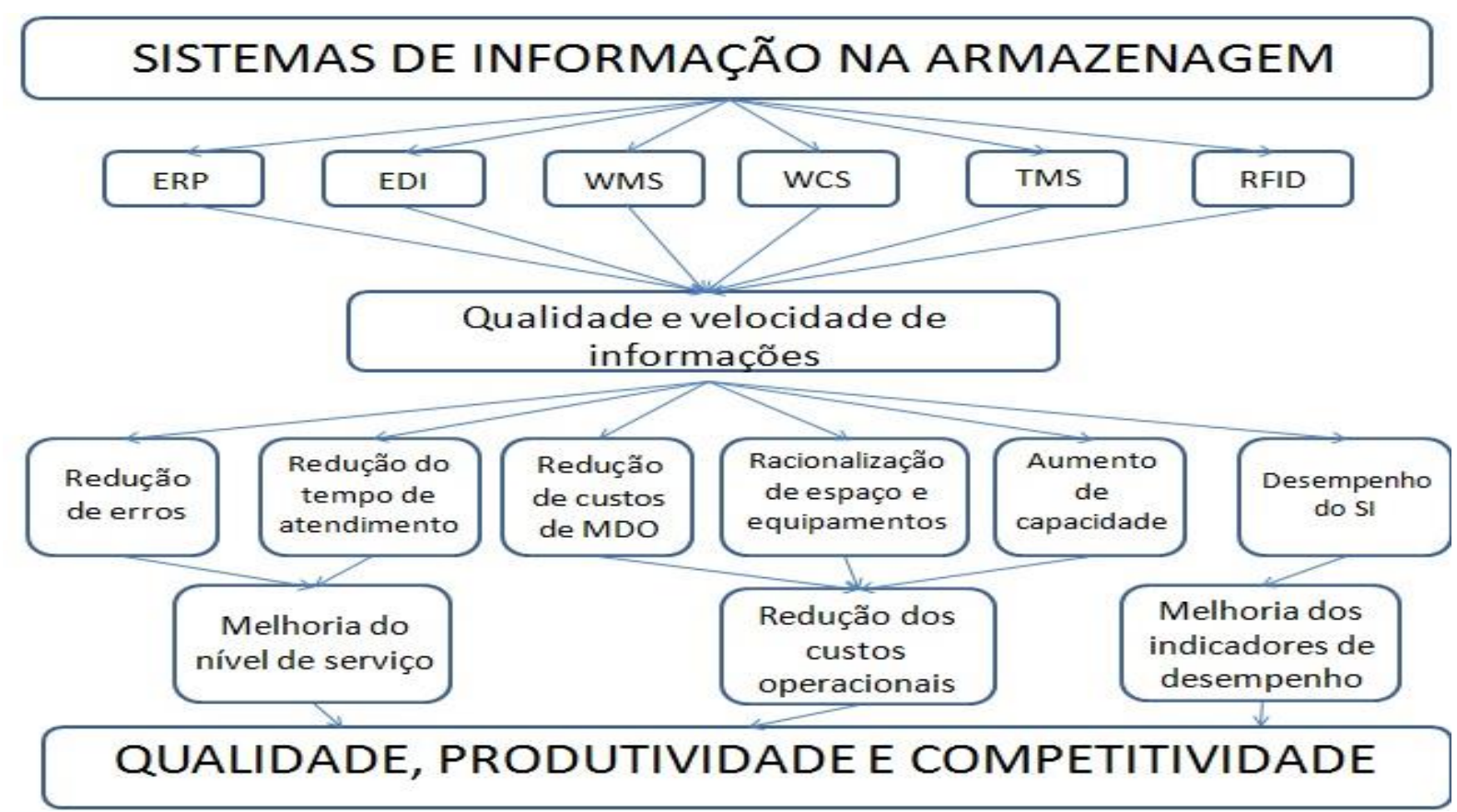

Figura 4 - Sistemas de informação na armazenagem.

Fonte: Adaptado de Banzato (2005).

Como identificado na figura acima, existem diversos sistemas informatizados que dão suporte à área de operações, dentre eles pode-se destacar: Enterprise Resource Planning/Sistemas Integrados de Gestão Empresarial (ERP), Electronic Data Interchange/Intercâmbio Eletrônico de Dados (EDI), Radio-Frequency Identification (RFID), Transportation Management System/Sistema de Gerenciamento de Transportes (TMS) e Warehouse Management System/Sistema de Gerenciamento de Armazém (WMS), entre outros. 
Todas estas ferramentas citadas são de grande valia para o aprimoramento dos processos operacionais, entretanto, focando na área de gestão da armazenagem, Viana (2002, p. 308) comenta que:

A evolução tecnológica, como não poderia deixar de ser, estendeu seus múltiplos benefícios à área de armazenagem, tanto pela introdução de novos métodos de racionalização e dos fluxos de distribuição de produtos, como pela adequação de instalações e equipamentos para movimentação física de cargas.

Além de novos equipamentos e instalações, destaca-se o desenvolvimento de tecnologias como o código de barras, a RFID (Etiqueta de Identificação Eletrônica via rádio-frequência) e o sistema WMS.

Com tal diversidade de opções, é importante que, no momento de escolher a tecnologia a ser aplicada à área de gestão da armazenagem, as organizações executem um planejamento anterior à implantação da ferramenta, isso em virtude do elevado custo envolvido na aquisição do software, treinamento de pessoal, implementação e manutenção da ferramenta, já que, em alguns casos, o investimento pode chegar às seis casas decimais (RIBEIRO; SILVA; BENVENUTO, 2005).

Quanto à definição da tecnologia a ser adotada, Bowersox, Closs e Cooper (2007, p. 25) salientam que as empresas que têm melhor desempenho

usam uma tecnologia da informação capaz de monitorar a atividade logística de forma global e em tempo real. Tal tecnologia identifica problemas operacionais potenciais e facilita a ação corretiva [...].

Isso contribui para a identificação de possíveis falhas operacionais e tomada de providências corretivas antes que as mesmas afetem o serviço prestado aos clientes.

Dentre as ferramentas tecnológicas aplicáveis à armazenagem, Dinter, Larhmann e Winter (2012, p. 176) destacam que "vários estudos confirmam a relevância da utilização de softwares de gestão como o business inteligence (BI) ou WMS na área de operações".

Como a presente dissertação centraliza o foco na solução WMS, a próxima seção é direcionada a explicar esse conceito que representa uma significativa fonte 
de vantagem competitiva para as organizações no que tange a área de gestão da armazenagem.

\subsection{WAREHOUSE MANAGEMENT SYSTEM (WMS)}

As organizações têm reconhecido a importância dos processos logísticos em oferecer vantagem competitiva em relação aos seus concorrentes. Segundo Loebbecke e Powell (1998), as empresas vêm aumentando o investimento em tecnologias da informação que propiciem uma maior eficiência operacional, o que envolve o conceito de WMS, foco principal da presente dissertação.

Sendo assim, as próximas seções versam a respeito de questões relevantes como a definição precisa desse conceito, as suas funcionalidades, os benefícios e as dificuldades de implementação, a fim de compreender o que o sistema representa em sua totalidade.

\subsubsection{Conceito}

A dinâmica advinda da globalização tem modificado a forma de atuação das organizações, bem como o grau de exigência dos consumidores. Nesse cenário, surgiram novas exigências de mercado, os pedidos de compra se tornaram mais frequentes e menores, o que força as organizações a trabalharem com um menor ciclo do pedido (lead time) que, segundo Slack (2009), é o tempo decorrido desde a efetivação do pedido pelo consumidor até a entrega do produto ou serviço.

Por estarem trabalhando com níveis de estoque mais baixos, os clientes exigem mais agilidade e demandam menor tempo de resposta dos seus fornecedores que, por sua vez, passam a ter que enxugar o seu ciclo de pedido, tornando-o mais veloz sem comprometer a qualidade do processo.

Comentando essa situação, Ribeiro, Silva e Benvenuto (2005) afirmam que os pedidos recebidos incompletos ou errados têm grande probabilidade de levar à falta de produtos e perdas de venda, tornando a tolerância a erros praticamente nula.

Para dar suporte a tais mudanças e possibilitar que as atividades operacionais sejam gerenciadas de forma eficiente, Pereira et al. (2010, p. 150) comentam que: 
Tornou-se necessária a utilização de sistemas de informação logísticos ou de gerenciamento da cadeia de suprimentos que, combinados com equipamentos e com a estrutura da empresa, tornam-se tecnologia da informação aplicada à logística.

Estes sistemas evidentemente têm como objetivo aprimorar a capacidade operacional do armazém no qual é aplicado, que pode ser feito de duas formas, segundo Banzato (2005, p. 56), "aumentando o seu tamanho ou aumentando o giro dos produtos, ou seja, movimentando-os de forma mais rápida fazendo com que os mesmos permaneçam o mínimo tempo no armazém".

Uma forma de obter essa agilidade é através da implantação do sistema WMS, como aponta Alves (2000, p. 151):

O WMS proporciona uma maior racionalidade e rapidez na localização e movimentação dos produtos, fazendo com que os mesmos permaneçam o mínimo tempo no CD. Assim, quanto mais rápido o estoque gira, maior é a "capacidade" de um armazém ou de um CD.

Explicando o conceito WMS, Rodrigues (2011, p. 5) afirma que este sistema pode ser definido como "a integração entre hardware, software e equipamentos periféricos para gerenciar estoque, espaço físico, equipamentos e mão de obra nas atividades de armazenagem".

Complementando, Banzato (2005, p. 53) explica que:

O WMS é um modelo de gestão de armazém, que otimiza todas as atividades operacionais (fluxo de materiais) e administrativas (fluxo de informações) dentro do processo de armazenagem, incluindo recebimento, inspeção, endereçamento, estocagem, separação, embalagem, carregamento, expedição, emissão de documentos, inventário, entre outras.

É através da melhoria destas atividades que o WMS aprimora a operação de um armazém, almoxarifado ou centro de distribuição, atingindo seus três grandes objetivos, que segundo Costa e Gobbo Junior (2008) são: (1) aumentar a precisão das informações de estoque; (2) aumentar a velocidade e qualidade das operações do armazém; (3) aumentar a produtividade do pessoal e dos equipamentos utilizados. 
Para atingir tais objetivos, o WMS registra e trabalha com diversas informações, que, de acordo com Ramos e Melo (2003), são provenientes de várias fontes, como transportadoras, área de produção, sistema integrado de gestão (ERP), clientes e/ou fornecedores. O sistema faz uso destas informações para realizar, controlar e gerenciar as atividades inerentes à área de armazenagem da melhor forma possível, buscando aprimorar o nível de serviço oferecido ao cliente.

De acordo com Banzato (2005, p. 54):

Nos sistemas WMS o nível de serviço ao cliente é o primeiro foco de melhoria, mantendo uma acuracidade de informações muito alta e minimizando os erros operacionais, evitando-se inclusive atividades de conferências e controles operacionais manuais. Isto acontece, devido à auto-verificação que faz parte do sistema WMS. Todas as atividades são executadas em tempo real e são confirmadas pelo WMS. Todas as atividades são controladas pelo WMS ao invés de serem feitas pelo operador. Este método assegura um melhor nível de serviço.

É importante ressaltar que o software do WMS não necessariamente é uma ferramenta à parte do ERP da empresa, nem tampouco trabalha de forma isolada em relação ao sistema corporativo, alguns desenvolvedores de ERP disponibilizam no próprio sistema um módulo WMS (ALVES, 2000).

Independentemente de ser um software à parte ou um módulo do ERP, uma questão relevante, segundo Ribeiro, Silva e Benvenuto (2005), é a sua capacidade de operar em tempo real entre múltiplos armazéns. Esse tipo de operação, que é realizada em combinação com o ERP da empresa, possibilita a visualização do status das mercadorias localmente ou à distância via terminais remotos ou consultas via Internet, possibilitando uma visão global dos produtos armazenados.

Por ser uma ferramenta adaptável a diversos tipos de operações, tem ocorrido um crescimento mundial no uso de sistemas de gerenciamento de armazéns. Tais melhorias ocorrem através do gerenciamento de informações e conclusão das tarefas diárias, em ambos os casos com um nível de controle adequado e boa acuracidade do estoque (COSTA; GOBBO JUNIOR, 2008).

Dessa forma, pode-se entender o WMS como um modelo de gestão das operações de armazenagem na cadeia de suprimentos que pode ser aplicado aos diversos elos da mesma (fornecedores, indústria, CDs, varejo ou atacado). Nesse contexto, o WMS mostra que a TI, quando bem utilizada, pode se tornar um forte 
diferencial competitivo entre as empresas na busca pela excelência no atendimento ao cliente (ALVES, 2000).

Feitas as considerações sobre o conceito WMS, os tópicos a seguir destacam as principais tecnologias que dão suporte a esse sistema.

\subsubsection{Tecnologias de suporte}

A parte operacional do processo de armazenagem é uma questão complexa que faz uso de algumas tecnologias de suporte para proporcionar uma maior eficiência à operação (MOELLER, 2011). Geralmente, quando um pedido é recebido, ele é convertido em uma lista impressa que informa os colaboradores responsáveis pela separação quais são os itens e as quantidades requisitadas pelo cliente. Além da guia, podem também ser utilizados coletores de código de barras, palms, rádio frequência (RFID), orientação por voz ou por luz (LUDWIG; GOOMAS, 2008).

Por isso, é importante que se compreenda como essas tecnologias contribuem para o bom funcionamento do WMS.

\subsubsection{Código de Barras}

$\mathrm{Na}$ armazenagem, a gestão da informação envolve o monitoramento das movimentações realizadas nos recebimentos de mercadoria, estocagem, transferência, separação, embalagem, expedição, dentre outras ocorrências.

Todos estes dados precisam ser registrados e, para tanto, uma tecnologia amplamente utilizada é o código de barras (Figura 5).

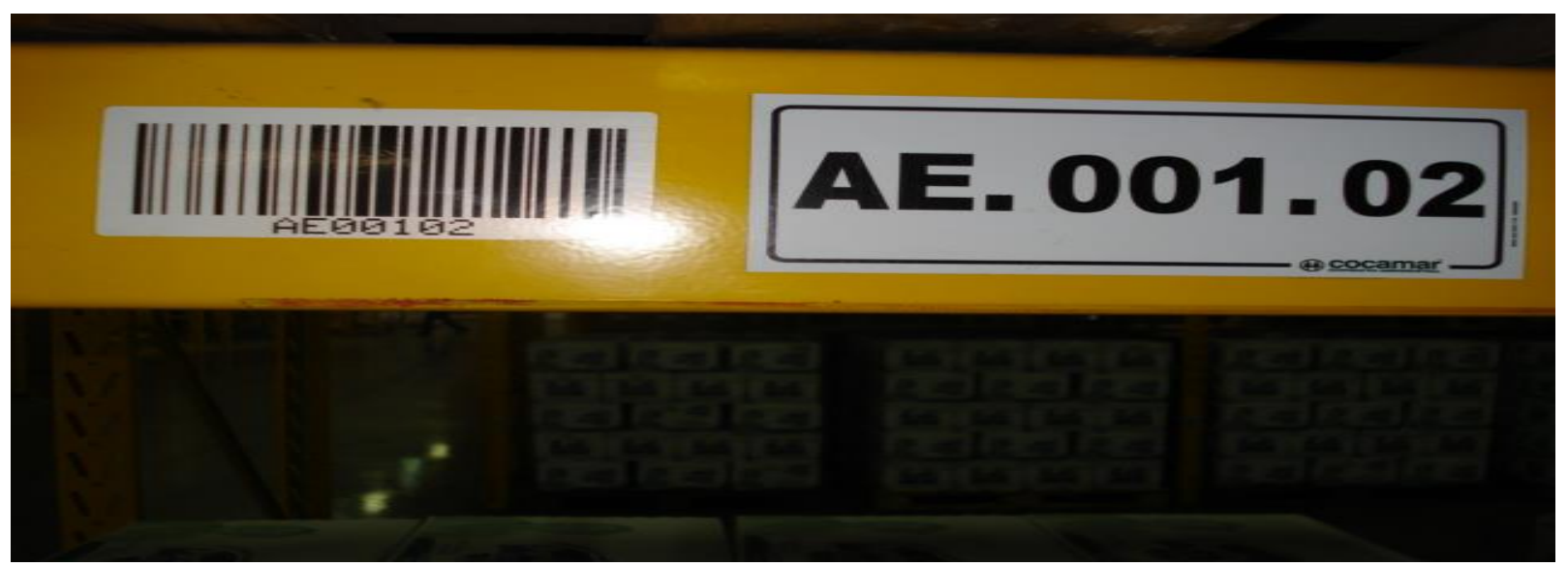

Figura 5 - Endereçamento. 
O código de barras pode conter inúmeras informações, desde a descrição do produto, lote, datas de fabricação e validade às informações referentes ao endereçamento (rua, corredor, andar, apartamento de armazenagem). Todas esses dados podem ser impressos no código de barras e anexadas a cada item ou ao endereço de armazenagem, eliminando as vias em papel, que há algum tempo eram feitas manual e lentamente.

Além do ganho em tempo comparado ao uso das vias em papel, outra vantagem do código de barras é a minimização da chance de erro no registro das informações, já que são provenientes de dados registrados no sistema da empresa e impressas automaticamente quando necessário.

Por trazer esses benefícios é que, segundo Martins e Alt (2006, p. 358), o código de barras "é o método mais usado para coletar dados para rastreamento, das fábricas aos supermercados [...]. No entanto, a tecnologia continua a requerer a intervenção humana", o que dá margem a falhas.

\subsubsection{RFID (Identificação por rádio frequência)}

O código de barras não é a única alternativa de TI disponível para o registro das operações de um armazém. Segundo Twist (2004), a automação dos armazéns está mudando com a entrada de uma nova tecnologia baseada em etiquetas eletrônicas inteligentes, chamadas tags, que emitem sinais de rádio frequência com as informações do produto, esta tecnologia denomina-se Radio Frequency Identification (RFID).

Basicamente o RFID possibilita a detecção e a identificação de um produto etiquetado através de uma antena, um transmissor (com codificador) e um transponder (chamado RF tag ou etiqueta eletrônica, programado com a informação necessária) localizados no armazém ou em diversos pontos da cadeia de suprimentos (inclusive em veículos). Dessa forma, existe a possibilidade real de acompanhamento online do posicionamento dos produtos na rede logística (BHUPTANI; MORADPOUR, 2005). 


\section{$\emptyset$}

Figura 6 - Tag RFID.

Fonte: TAG RFID UFH (2012).

A tag RFID é, segundo Martins e Alt (2006, p. 359):

Um salto gigantesco no campo da coleta automática de dados. Enquanto o código de barras exige um alinhamento das barras com o scanner para leitura, o RFID usa ondas de rádio, que permitem ler até o código do que está dentro do contêiner sem abri-lo.

Um ponto interessante é a ampla gama de aplicações possíveis para essa tecnologia, podendo ser aplicada no monitoramento da movimentação de materiais, pessoas, equipamentos e veículos, gerando informações precisas do trabalho que efetivamente está sendo realizado, o que garante um maior controle sobre a operação.

\subsubsection{Coletores e Antenas}

Ambas as tecnologias citadas (código de barras e RFID) são ferramentas eficientes ao suporte para a utilização do WMS. Entretanto, elas têm algumas diferenças quanto a sua operacionalização. Quando há o uso do código de barras, a leitura e os registros de movimentação são feitos através dos chamados coletores de código de barras, conforme ilustra a Figura 7.

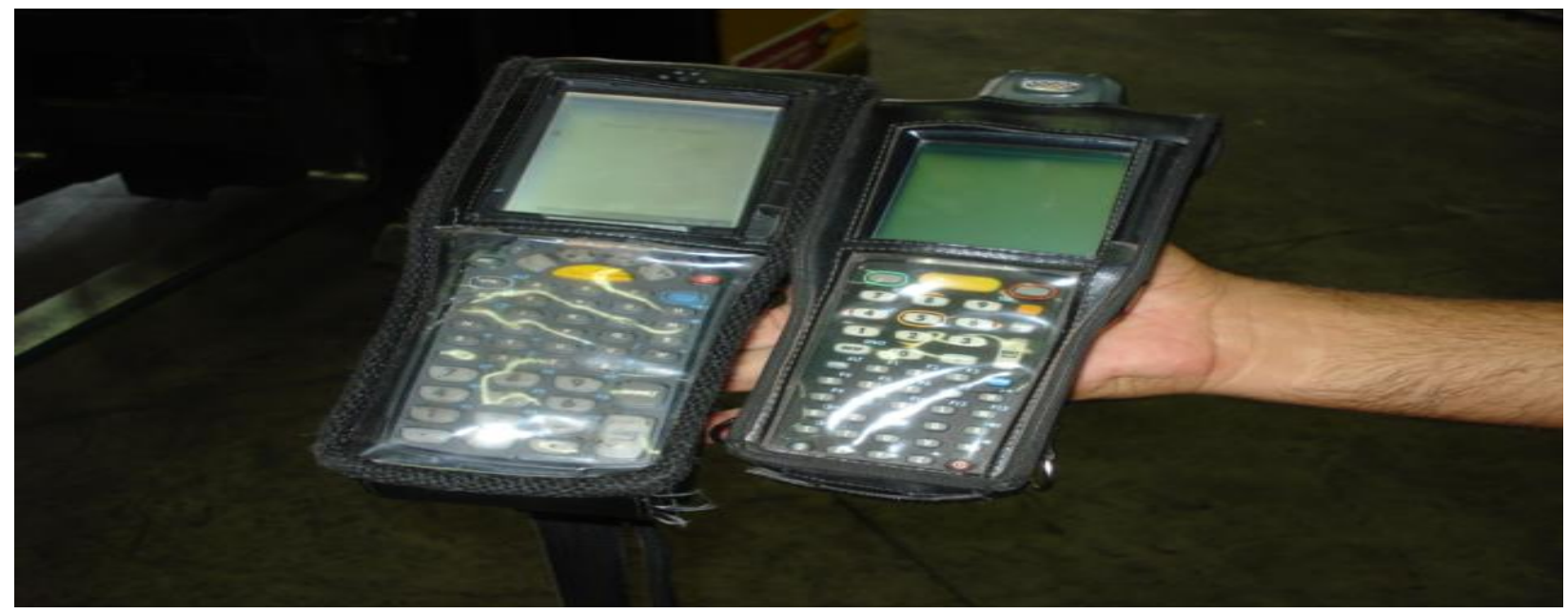

Figura 7 - Coletores de código de barras. 
Já as etiquetas eletrônicas (tags) não necessitam dessas leituras, pois emitem um sinal de rádio frequência que é capitado através de antenas que direcionam a informação de localização em tempo real para o ERP da empresa, conforme mostra a Figura 8.

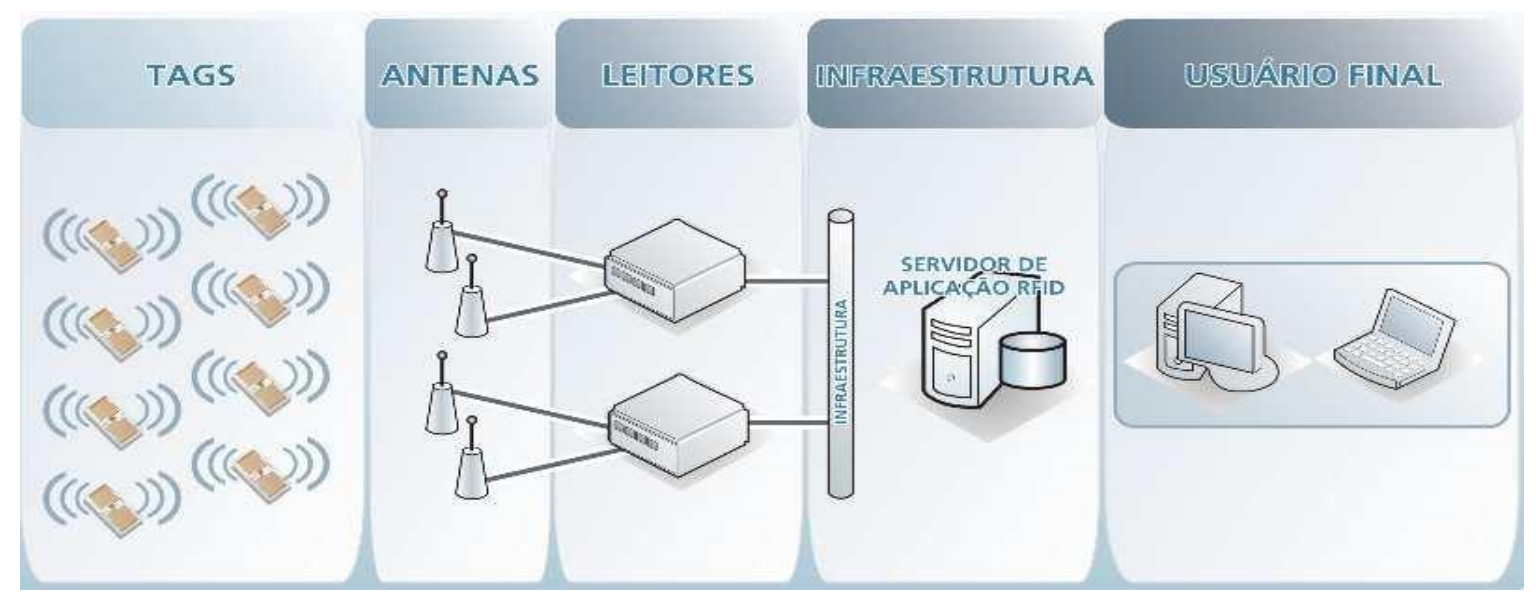

Figura 8 - Processo de captação do sinal de rádio frequência. Fonte: RFID (2012).

A operação que faz uso da tecnologia RFID minimiza ainda mais a chance de registros equivocados de movimentação, já que não é necessária a confirmação por parte do operador de empilhadeira.

Compreendendo melhor as tecnologias que dão suporte ao WMS, fica mais fácil entender os benefícios que, segundo a literatura, esse sistema de gestão pode oferecer às organizações que o utilizam, tema abordado pela próxima seção.

\subsubsection{Benefícios do WMS}

Esse tópico aborda os benefícios proporcionados pelo WMS. Segundo Banzato (2005, p. 53), "o WMS pode otimizar o negócio da empresa em duas grandes categorias: redução de custo e melhoria do serviço ao cliente", ambas as questões são aprimoradas por meio dos seguintes fatores destacados pelo autor:

- Melhoria da acuracidade de estoque;

- Melhoria na ocupação do espaço;

- Redução de erros operacionais;

- Aumento da produtividade;

- Redução da necessidade de papéis;

- Melhoria no controle de carga de trabalho; 
- Melhoria no gerenciamento operacional;

- Apoio ao processo de aumento de valor agregado ao cliente;

- Redução do tempo de pedido em espera;

- Otimização do percurso de separação de pedidos;

- Estocagem otimizada através do endereçamento pela curva $A B C$;

Complementando essa relação, Alves (2000) comenta sobre o monitoramento online da operação de armazenagem, afirmando que o WMS pode apoiar reduções nos lead times, tanto para o processamento de pedidos quanto para 0 gerenciamento de inventário e rotinas diárias.

Adicionalmente, o WMS pode otimizar as rotas de apanha e coleta percorridas pelos operadores no armazém, objetivando a redução da distância percorrida na separação dos pedidos e, consequentemente, do tempo e do custo inerentes a essa operação. Ainda focado na eficiência da movimentação interna, o WMS define o endereçamento e a localização dos produtos dentro do armazém, a partir de lógicas que utilizam critérios definidos de acordo com as características do produto, da estrutura de armazenagem disponível e demais restrições operacionais informadas no sistema (CHIANG;LIN; CHEN, 2011).

Vaidyanathan e Devaraj (2008) ainda destacam a melhor visibilidade do estoque, aprimoramento da acuracidade de estoque, pois estes incrementam significativamente a eficiência da separação de pedidos, a atividade mais onerosa dentre as que compõem a operação de armazenagem.

Os benefícios apresentados são alcançados através da utilização das funcionalidades existentes no sistema WMS, descritas na próxima seção.

\subsubsection{Funcionalidades do WMS}

O WMS é uma ferramenta complexa que pode exercer uma ampla gama de funções, variando de acordo com o tipo de organização, segmento de atuação e o posicionamento da empresa na cadeia de suprimentos.

Além disso, a identificação e descrição das funcionalidades do sistema WMS na literatura consultada traz o inconveniente das divergências de interpretações e formas de expressão - diversos autores citam as mesmas aplicações utilizando 
diferentes formas de descrição. Sendo assim, com o intuito de facilitar a visualização e compreensão, foi elaborado o Quadro 1.

\begin{tabular}{|c|c|c|c|}
\hline Banzato (2005) & Banzato et al. (2010) & $\begin{array}{c}\text { Bowersox, Closs e } \\
\text { Cooper (2007) }\end{array}$ & $\begin{array}{c}\text { Costa e Gobbo Junior } \\
\text { (2008) }\end{array}$ \\
\hline $\begin{array}{c}\text { Programação e entrada } \\
\text { de pedidos }\end{array}$ & $\begin{array}{c}\text { Programação e entrada } \\
\text { de pedidos }\end{array}$ & Arrumação & $\begin{array}{c}\text { Rastreabilidade das } \\
\text { operações }\end{array}$ \\
\hline $\begin{array}{c}\text { Planejamento e } \\
\text { alocação de recursos }\end{array}$ & Controle de portaria & $\begin{array}{c}\text { Separação e } \\
\text { reabastecimento }\end{array}$ & $\begin{array}{l}\text { Inventários físicos } \\
\text { rotativos e gerais }\end{array}$ \\
\hline Portaria & Controla o estoque & Armazenagem & $\begin{array}{c}\text { Planejamento e } \\
\text { controle de } \\
\text { capacidades }\end{array}$ \\
\hline Recebimento & Controle de lotes & Cross-docking & $\begin{array}{l}\text { Definição de } \\
\text { características de cada } \\
\text { local de armazenagem }\end{array}$ \\
\hline Estocagem & Integração com RFID & $\begin{array}{l}\text { Estratégia de } \\
\text { Separação }\end{array}$ & $\begin{array}{c}\text { Sistema de } \\
\text { classificação dos itens }\end{array}$ \\
\hline Transferências & $\begin{array}{l}\text { Atualização on-line o } \\
\text { saldo em estoque }\end{array}$ & Simulações & Controle de lotes \\
\hline Separação de Pedidos & $\begin{array}{c}\text { Endereçamento } \\
\text { automático }\end{array}$ & $\begin{array}{c}\text { Gerenciamento de } \\
\text { devoluções }\end{array}$ & $\begin{array}{c}\text { Apoio à separação de } \\
\text { pedidos }\end{array}$ \\
\hline Expedição & $\begin{array}{c}\text { Analisa a produtividade } \\
\text { da mão-de-obra }\end{array}$ & Recebimento & $\begin{array}{c}\text { Interface com clientes } \\
\text { e fornecedores }\end{array}$ \\
\hline Inventários & Prioriza tarefas & Controle de estoque & $\begin{array}{c}\text { Calculo de embalagens } \\
\text { de despacho }\end{array}$ \\
\hline $\begin{array}{c}\text { Controle de } \\
\text { Contenedores }\end{array}$ & $\begin{array}{c}\text { Determina a rota de } \\
\text { separação }\end{array}$ & $\begin{array}{l}\text { Gerenciamento da } \\
\text { carga de trabalho }\end{array}$ & $\begin{array}{l}\text { Controle de rotas de } \\
\text { movimentação interna }\end{array}$ \\
\hline $\begin{array}{l}\text { Controle do } \\
\text { Desempenho } \\
\text { Operacional }\end{array}$ & Controla cross-docking & Embarque & $\begin{array}{c}\text { Controle de } \\
\text { carregamento dos } \\
\text { veículos }\end{array}$ \\
\hline Relatórios & Forma "kits" & $\begin{array}{l}\text { Gerenciamento de } \\
\text { pátio }\end{array}$ & \\
\hline $\begin{array}{c}\text { Organização do } \\
\text { percurso de separação } \\
\text { de pedidos }\end{array}$ & $\begin{array}{l}\text { Confirma embarque e } \\
\text { liberação de veículos }\end{array}$ & $\begin{array}{l}\text { Gerenciamento da } \\
\text { mão-de-obra }\end{array}$ & \\
\hline Endereçamento & $\begin{array}{c}\text { Programa a } \\
\text { manutenção de } \\
\text { veículos }\end{array}$ & $\begin{array}{l}\text { Otimização de } \\
\text { armazéns }\end{array}$ & \\
\hline \multirow[t]{9}{*}{$\begin{array}{c}\text { Priorização de tarefas } \\
\text { urgentes }\end{array}$} & $\begin{array}{c}\text { Reconhece as } \\
\text { limitações físicas dos } \\
\text { endereços }\end{array}$ & $\begin{array}{c}\text { Serviços com valor } \\
\text { agregado }\end{array}$ & \\
\hline & $\begin{array}{c}\text { Planejamento e } \\
\text { alocação de recursos }\end{array}$ & & \\
\hline & $\begin{array}{c}\text { Analisa o desempenho } \\
\text { da mão-de-obra }\end{array}$ & & \\
\hline & $\begin{array}{l}\text { Apresenta relatórios do } \\
\text { "status" do veículo }\end{array}$ & & \\
\hline & $\begin{array}{c}\text { Auxilia no projeto do } \\
\text { layout de } \\
\text { armazenagem }\end{array}$ & & \\
\hline & Controla contenedores & & \\
\hline & $\begin{array}{c}\text { Determina a prioridade } \\
\text { de descarga }\end{array}$ & & \\
\hline & $\begin{array}{c}\text { Reserva de docas e } \\
\text { programa de carga e } \\
\text { descarga }\end{array}$ & & \\
\hline & Gerencia o pátio & & \\
\hline
\end{tabular}

Quadro 1 - Funcionalidades do WMS segundo a literatura. 
Após essa compilação, foi elaborado o Quadro 2, que resume e elimina as informações redundantes presentes no quadro anterior.

\begin{tabular}{|c|c|}
\hline Funcionalidade & Descrição \\
\hline $\begin{array}{l}\text { Programação da entrada de } \\
\text { pedidos, portaria e } \\
\text { gerenciamento de pátio. }\end{array}$ & $\begin{array}{l}\text { Definição do momento no qual um pedido será separado de } \\
\text { acordo com a disponibilidade de produtos em estoque e urgência } \\
\text { do mesmo. Também realiza o controle de portaria, programando } \\
\text { data e hora de entrada. } \\
\text { Além disso, monitora todo o andamento do processo de } \\
\text { embarque ou desembarque. }\end{array}$ \\
\hline $\begin{array}{l}\text { Planejamento e alocação de } \\
\text { recursos }\end{array}$ & $\begin{array}{l}\text { Faz o planejamento da necessidade de horas de trabalho de } \\
\text { pessoal e equipamentos necessários para a realização das } \\
\text { atividades programadas para atender a demanda diária de } \\
\text { recebimento, movimentação e expedição de um ou mais } \\
\text { armazéns. } \\
\text { Aloca os recursos adequados no momento e local onde são } \\
\text { necessários (ex: empilhadeiras com torres de alturas diferentes). }\end{array}$ \\
\hline Pré-recebimento & $\begin{array}{l}\text { Programação do recebimento de mercadorias conforme } \\
\text { disponibilidade e urgência. }\end{array}$ \\
\hline Recebimento & $\begin{array}{l}\text { Execução, acompanhamento, registro e controle do recebimento } \\
\text { de materiais. }\end{array}$ \\
\hline Estocagem & $\begin{array}{l}\text { Endereçamento automático segundo limitações dos endereços } \\
\text { de armazenagem registradas, curva ABC, FIFO e demais } \\
\text { restrições cadastradas no sistema. } \\
\text { Registro de todas as movimentações internas e transferências de } \\
\text { forma a alocar racionalmente os produtos, minimizando a } \\
\text { ociosidade e organizando a área de armazenagem. }\end{array}$ \\
\hline Separação de Pedidos & $\begin{array}{l}\text { Definição do operador, da sequência dos pedidos a serem } \\
\text { separados e da melhor rota a ser executada para que o trabalho } \\
\text { seja realizado no menor tempo possível. }\end{array}$ \\
\hline Inventários & $\begin{array}{l}\text { Suporte, acompanhamento, registro e controle na realização de } \\
\text { inventários cíclicos ou gerais. } \\
\text { Identificando, monitorando e rastreando diferenças de estoque. }\end{array}$ \\
\hline Controle de Contenedores & $\begin{array}{l}\text { Controle de quantidade, tipo, disponibilidade e localização de } \\
\text { contenedores utilizados. }\end{array}$ \\
\hline $\begin{array}{l}\text { Controle do Desempenho } \\
\text { Operacional }\end{array}$ & $\begin{array}{l}\text { Oferece indicadores de desempenho da área de gestão da } \\
\text { armazenagem que relatam a performance do armazém, } \\
\text { destacando informações que dão suporte ao acompanhamento } \\
\text { da rotina. } \\
\text { Ex: produtividade da mão-de-obra, status de ocupação do } \\
\text { armazém e do carregamento, dentre outros. }\end{array}$ \\
\hline Priorização de tarefas urgentes & $\begin{array}{l}\text { Prioriza recebimentos, expedições e demais movimentações de } \\
\text { produtos com base no seu grau de importância e urgência. }\end{array}$ \\
\hline Integração com EDI & $\begin{array}{l}\text { O WMS pode estar integrado com a cadeia de suprimentos } \\
\text { através da interface disponibilizada pelo EDI. Dessa forma, } \\
\text { compartilhando informações inerentes à operação. }\end{array}$ \\
\hline $\begin{array}{l}\text { Inspeção e controle de } \\
\text { qualidade }\end{array}$ & $\begin{array}{l}\text { Registro de informações como não conformidades ou controle de } \\
\text { quarentena para a liberação de lotes. }\end{array}$ \\
\hline Rastreabilidade & $\begin{array}{l}\text { Registra todas as informações sobre um lote de produtos } \\
\text { produzido ou recebido. Desde a data de produção, item, data de } \\
\text { liberação de quarentena, veículo expedido, operador responsável } \\
\text { pela movimentação, destino de embarque, dentre outros. } \\
\text { Dessa forma possibilitando o rastreamento de qualquer lote } \\
\text { manuseado pela operação. }\end{array}$ \\
\hline Integração com RFID & $\begin{array}{l}\text { Pode trabalhar em consonância com o WMS, agilizando a } \\
\text { operação, pois não tem a necessidade de registro das } \\
\text { movimentações pelos operadores. Esta é realizada } \\
\text { automaticamente, através das tags. }\end{array}$ \\
\hline
\end{tabular}




\begin{tabular}{|c|c|}
\hline Funcionalidade & Descrição \\
\hline $\begin{array}{c}\text { Atualiza "on-line" o saldo em } \\
\text { estoque }\end{array}$ & $\begin{array}{l}\text { Atualiza o saldo em estoque de todos os produtos a partir do } \\
\text { momento que é registrada a produção, devolução, expedição, } \\
\text { recebimento ou transferência do mesmo. }\end{array}$ \\
\hline Controla cross-docking & $\begin{array}{l}\text { Programa data e hora para a realização do cross-dociking, } \\
\text { otimizando a velocidade de movimentação da operação. }\end{array}$ \\
\hline Forma "kits & Auxilia na formação de "kits" conforme demandado pelo cliente. \\
\hline $\begin{array}{l}\text { Prepara documentos de } \\
\text { expedição }\end{array}$ & Prepara documentos que acompanham o veículo expedido. \\
\hline $\begin{array}{l}\text { Programa a manutenção de } \\
\text { veículos }\end{array}$ & $\begin{array}{l}\text { Programa a manutenção dos equipamentos de movimentação } \\
\text { interna utilizados. }\end{array}$ \\
\hline Simulações & $\begin{array}{l}\text { Faz simulações de atividades e tendências de futuras } \\
\text { necessidades da área de armazenagem. }\end{array}$ \\
\hline Gerenciamento de devoluções & Programa, recebe e controla as devoluções existentes. \\
\hline Serviços com valor agregado & $\begin{array}{l}\text { Propicia a prestação de serviços de valor agregado para } \\
\text { empresas que trabalham com prestador de serviço logístico. }\end{array}$ \\
\hline $\begin{array}{l}\text { Calculo de embalagens de } \\
\text { despacho }\end{array}$ & $\begin{array}{l}\text { Calcula a necessidade de embalagens para expedição dos } \\
\text { pedidos em carteira. }\end{array}$ \\
\hline
\end{tabular}

Quadro 2 - Funcionalidades do WMS consolidadas.

Realizada a compilação e as considerações quanto às funcionalidades do WMS relatadas pela literatura consultada, a próxima seção abordará as dificuldades e barreiras existentes para a adoção e implantação desse sistema de gestão.

\subsubsection{Dificuldades e Barreiras}

O WMS oferece diversos benefícios, entretanto, para que estes possam ser atingidos, existem algumas dificuldades, como destacam Banzato et al. (2010):

- O alto montante de investimento inicial;

- O frequente baixo conhecimento dos colaboradores sobre a ferramenta;

- A resistência à mudança por parte dos funcionários;

- O treinamento e capacitação do pessoal envolvido na operação;

- A remodelagem e adaptação dos processos operacionais;

- A Integração entre hardware, software e os colaboradores.

Complementando a listagem destas barreiras, Fleury, Wanke e Figueiredo (2000) abordam a fase de implementação deste sistema. De acordo com os autores, mesmo com altos investimentos de recursos financeiros e humanos, existe a possibilidade dessa mudança não ter o sucesso almejado, geralmente porque alguma etapa da implementação não foi adequadamente planejada e/ou monitorada pelo gestor responsável.

No intuito de amenizar esse problema, os autores elaboraram um projeto de implementação do WMS, conforme ilustrado pela Figura 9. 
Boa parte dos autores explica que a cultura é um conjunto de conhecimentos, crenças, artes, normas, costumes e outros hábitos adquiridos pelo ser humano em suas relações enquanto membro da sociedade (RATTNER, 1998).

Sendo produto da relação entre os seres humanos, é possível identificar que existem também as chamadas culturas organizacionais. Segundo Barbosa (1996), o conceito de cultura é abordado no campo da administração sob um foco instrumental. Frequentemente observa-se no mercado a definição de uma cultura organizacional como sendo "forte ou fraca", "boa ou má", "eficiente ou ineficiente", com o intuito de identificar as questões que devem ser aprimoradas e melhor gerenciadas, de forma a contribuir para a melhor rentabilidade da organização.

Nesse sentido, Mascarenhas (2004, p. 39) explica que "a abordagem típica da administração tende a considerar a cultura um sistema fechado e reconhecível como padrão de um grupo". Sendo assim, a cultura seria passível de gestão, considerando que o responsável pelas atividades de um setor tem condições de identificar o padrão cultural existente no grupo sob sua responsabilidade e trabalhar as suas características de forma a gerar maior produtividade e eficiência.

Sob esta ótica, Santos (2005) afirma que nas décadas de 50 e 60 surgiram premissas sobre a universalidade das práticas administrativas em que modelos e processos de gestão adotados no Japão, por exemplo, poderiam ser praticados em outros países, sendo adequados a qualquer cultura.

Entretanto essa ideia foi contestada e refutada nos anos 80, visto que cada país possui configurações culturais próprias e distintas, além de diferenças dentro de uma mesma nação, inerentes a regiões, classes sociais, idade, sexo, dentre outras características. Diferenças estas que podem gerar reflexos em questões como estilo de liderança, motivação e processo de tomada de decisão (HOFSTEDE, 1998).

Essa influência atinge diversas áreas da organização, entretanto, segundo Salgado Junior (2004), é comum a existência de problemas relacionados ao processo de absorção tecnológica em virtude da resistência cultural à mudança decorrente das alterações nas atividades diárias. Esta situação leva a organização a passar por "transtornos" no processo de implementação de um sistema, o que acarreta em aumento do tempo de implantação, incompatibilidade interna e até no próprio processo de retirada do sistema. 
Visando minimizar tal impacto negativo nas operações organizacionais, Fernandes (2001) salienta que a compreensão e adaptação à mudança podem ser obtidas por meio do treinamento dos colaboradores envolvidos, desenvolvendo competências e um melhor entendimento do que de fato a adoção da nova tecnologia representa para a organização, trabalhando dessa forma a cultura organizacional.

Corroborando, Alves (2000) explica que o treinamento e preparação dos colaboradores quanto à adoção de uma cultura de trabalho diferente, advinda da alteração da forma de trabalho ou das atividades executadas, mostra-se como um fator importante para que essa transição ocorra de forma eficiente, gerando assim os resultados positivos esperados.

Sendo a questão da mudança cultural um fator significante para a boa adaptação dos colaboradores quanto à adoção de novas tecnologias ou novos processos, evidentemente isso influencia também no sucesso da implementação do WMS. 


\section{PROCEDIMENTOS METODOLÓGICOS}

Este capítulo aborda os métodos, procedimentos e técnicas adotados para que fosse possível atingir os objetivos traçados, portanto, é importante compreender claramente o conceito básico do que é de fato a pesquisa.

Pode-se definir este conceito como "o procedimento racional e sistemático que tem como objetivo proporcionar respostas aos problemas que são propostos" (GIL, 2009, p. 17). Ocorre a necessidade deste tipo de investigação quando não se tem informação suficiente para responder ao problema ou quando a mesma se encontrar desordenada, o que inibe a possibilidade de resolução do questionamento.

Para resolver o problema proposto, Richardson (1999) explica que a pesquisa é desenvolvida mediante a utilização de métodos, técnicas e outros procedimentos científicos, fatores necessários para o entendimento dos fenômenos estudados.

Por método, Andrade (2004, p. 22) entende como "o caminho que se percorre na busca pelo conhecimento", ou seja, o caminho percorrido para que os objetivos sejam atingidos, respondendo assim as dúvidas existentes sobre determinado tema.

Ruiz (2002, p. 137) contribui explicando que "a palavra método é de origem grega e significa o conjunto de etapas e processos a serem vencidos ordenadamente na investigação dos fatos ou na procura da verdade".

Apesar de serem conceitos distintos, é comum a ocorrência de dúvida em relação ao método e à técnica. Explicando essa diferença, Severino (2002, p. 162) pontua que "entende-se por métodos os procedimentos mais amplos de raciocínio, enquanto técnicas são procedimentos mais restritos que operacionalizam os métodos, mediante o emprego de instrumentos adequados".

\subsection{TIPO DE PESQUISA}

A presente dissertação classifica-se como sendo descritiva aplicada, pois retrata e analisa fatos já ocorridos nas organizações estudadas. Segundo Andrade (2004, p. 32), "nesse tipo de pesquisa, os fatos são observados, registrados, analisados, classificados e interpretados, sem que o pesquisador interfira sobre eles", o que significa dizer que os fenômenos são estudados, mas não manipulados pelo pesquisador. 
Neste sentido, Oliveira Neto (2008) comenta que a pesquisa descritiva aplicada é caracterizada pelo interesse prático, de forma que a análise e interpretação de fenômenos atuais contribuam significativamente para a resolução de problemas que ocorrem na realidade.

Desse modo, este trabalho acadêmico tem caráter qualitativo, ao analisar informações provenientes da referencial teórico e de um estudo multicasos realizado com cinco empresas, definidas de forma que fosse possível a obtenção de informações suficientes para a resolução dos objetivos propostos.

\subsubsection{Perguntas de investigação}

A elaboração de perguntas de investigação foi realizada com base nos objetivos estabelecidos e norteiam o pesquisador durante a busca das informações em campo:

- Quais são as novas funcionalidades e benefícios oferecidos pelos desenvolvedores do WMS?

- Quais foram as dificuldades encontradas no processo de implantação do WMS, as adaptações necessárias e os benefícios percebidos?

- As empresas estudadas conseguem atingir todos os benefícios oferecidos pelo WMS?

\subsubsection{Proposições de pesquisa}

As perguntas de pesquisa definidas anteriormente podem ser traduzidas em proposições a fim de auxiliar melhor orientar o foco da dissertação. Cooper e Schindler (2003, p. 57) explicam que estas "são declarações sobre conceitos que podem ser julgados como verdadeiros ou falsos caso se refiram a fenômenos observáveis".

Identificou-se que, no cenário nacional, as empresas têm uma deficiência no entendimento e conhecimento das funcionalidades e benefícios que atualmente 0 WMS pode oferecer (BANZATO et al., 2010). Sobre esse tema foram definidas as seguintes preposições: 
- As empresas usuárias comumente não utilizam todas as funcionalidades disponíveis no WMS, dentre outros fatores, em virtude do baixo conhecimento sobre a ferramenta;

- As empresas usuárias não utilizam todas as funcionalidades disponíveis no WMS, dentre outros fatores, pela falta de investimento das organizações no número de colaboradores necessário para executar adequadamente as atividades inerentes à gestão da armazenagem;

- A preparação prévia da cultura da organização é um fator que contribui positivamente para uma implantação de WMS bem sucedida;

- Na visão das empresas que adotam o WMS a maior dificuldade é a mudança cultural;

- Há falhas no treinamento dos colaboradores que trabalham com o WMS nas organizações;

- Existem atualmente funcionalidades do WMS que integram operação do armazém à cadeia de suprimentos da qual a empresa faz parte;

- Geralmente as expectativas iniciais quanto à implantação do WMS são superadas.

\subsubsection{Definição das variáveis}

A definição das variáveis a serem estudadas foi realizada com base no referencial teórico levantado através da consulta a artigos e livros. Lakatos e Markoni (2010) explicam que uma variável pode ser considerada uma classificação ou medida, uma quantidade que varia, um conceito operacional que apresenta valores e que é passível de mensuração.

Além do estudo dessas variáveis em empresas que implementaram o sistema WMS (usuários), foram realizadas também entrevistas com desenvolvedores do sistema WMS com o intuito de identificar os benefícios e funcionalidades disponíveis atualmente no mercado, definindo-se as seguintes variáveis: 


\begin{tabular}{|c|c|}
\hline Indicador & Variável \\
\hline \multirow{4}{*}{ Gestão de pessoas } & Conhecimento do conceito WMS antes da implantação \\
\hline & Preparação e treinamento pré-implantação do WMS \\
\hline & Mapeamento e alinhamento dos processos organizacionais \\
\hline & Apoio da alta gerência \\
\hline \multirow{2}{*}{$\begin{array}{l}\text { Tecnologia da } \\
\text { Informação }\end{array}$} & Adequação às necessidades da operação \\
\hline & Integração com a tecnologia já adotada pela empresa \\
\hline \multirow{3}{*}{$\begin{array}{l}\text { Velocidade } \\
\text { operacional }\end{array}$} & Aumento da velocidade de recebimento \\
\hline & Aumento da velocidade de separação de pedidos \\
\hline & Aumento na velocidade de identificação de falhas \\
\hline \multirow{17}{*}{$\begin{array}{c}\text { Controle da } \\
\text { operação }\end{array}$} & Programação e sequenciamento do recebimento \\
\hline & Controle de portaria e pátio \\
\hline & Erros de conferência no recebimento \\
\hline & Melhor utilização do espaço disponível \\
\hline & Melhor visualização do estoque \\
\hline & Controle de lotes (rastreabilidade, FIFO) \\
\hline & Gerenciamento de devoluções \\
\hline & Programação e sequenciamento da separação de pedidos \\
\hline & Erros na separação do pedido \\
\hline & Erros de conferência no carregamento \\
\hline & Priorização de atividades \\
\hline & Inventário - acuracidade de estoque \\
\hline & Distribuição e controle da carga de trabalho \\
\hline & Monitoramento do desempenho do colaborador \\
\hline & Monitoramento e controle de produtividade por atividade \\
\hline & Variação do nível de serviço prestado \\
\hline & Variação do nível de estoque \\
\hline
\end{tabular}

Quadro 3 - Resumo das variáveis analisadas nos usuários do WMS.

Conforme mencionado anteriormente, visando responder às proposições de pesquisa através do estudo das variáveis citadas, definiu-se como meios para a obtenção de informações acerca do tema o uso da revisão bibliográfica e do estudo de multicasos, com coleta de dados orientada pelo protocolo para o estudo de caso apresentado por Yin (2009).

\subsection{PROTOCOLO DE PESQUISA}

O protocolo de estudo de caso contém o instrumento, procedimentos e as regras gerais a serem seguidas pelo pesquisador durante a análise de determinado objeto de estudo.

Segundo Yin (2009, p. 106):

É uma forma de aumentar a confiabilidade da pesquisa de estudo de caso, pois ele se destina a orientar o pesquisador quanto aos procedimentos de coleta de dados [...] ter um protocolo de estudo de caso é desejável sob todas as circunstâncias, mas é essencial se você estiver realizando um estudo de casos múltiplos. 
Esclarecendo as partes componentes do protocolo de pesquisa, o autor descreve as quatro principais seções como:

- Visão geral do projeto de estudo de caso (objetivos, assuntos do estudo, leituras relevantes pertinentes);

- Procedimentos de campo (referente à coleta de dados, lista-se os locais a serem visitados, bem como as pessoas de contato);

- Questões de estudo de caso (questões que o pesquisador deve ter em mente na coleta de dados, organizadas de forma estruturada em tabelas);

- Um guia para o relatório do estudo de caso.

$\mathrm{Na}$ seção a seguir, a descrição das informações inerentes aos estudos de caso realizados neste trabalho acadêmico: plano amostral, pessoas-chave para entrevistas, técnicas e instrumentos de coleta de dados, procedimentos para coleta e análise de dados.

\subsubsection{Plano amostral}

No Brasil, segundo Banzato et al. (2010), não há abundância de empresas que já tenham passado pela implementação do WMS e que, portanto, possam ofertar informações que agreguem conteúdo a esta dissertação.

Além disso, em virtude da complexidade do tema abordado e do intuito do pesquisador de compreender profundamente o objeto de estudo, cabe a este trabalho a seleção de poucos casos. Porém, é importante ressaltar que os mesmos devem proporcionar uma vasta gama de informações, de forma a atender os objetivos propostos, confirmando ou contrariando as proposições de pesquisa.

Nesse sentido, por conveniência, foram escolhidas cinco empresas - dois desenvolvedores de software (Sythex e PC Sistemas) e três organizações usuárias do WMS (Distribuidora X, Atacado $Y$ e Companhia de Bebidas Ipiranga), melhor descritas na seção 4 Estudos de Caso.

\subsubsection{Pessoas-chave para entrevistas}

Esse tópico definiu os cargos que participaram das entrevistas realizadas, com base no conhecimento e grau de participação em atividades como desenvolvimento, implementação, operacionalização e gestão do sistema WMS. 
- Gerente de Logística;

- Coordenador / Supervisor de Operações (Armazenagem);

- Analistas (participantes da operação com o uso do WMS);

- Pessoal operacional (operador de empilhadeira, estoquista, líder de pátio);

- Coordenador / Gerente de TI;

- Programador do software WMS.

\subsubsection{Técnicas e instrumentos de coleta de dados}

As técnicas de coleta de dados utilizadas nas empresas analisadas foram a entrevista semiestruturada, observação não-participante e análise documental.

Para entrevistas em tipos distintos de empresas foram desenvolvidos dois roteiros de pesquisa - um para empresas desenvolvedoras do software WMS (apêndice A) e outro para organizações usuárias do sistema (apêndice B).

As entrevistas foram agendadas conforme a disponibilidade das pessoaschave respondentes e ocorreram na quantidade e com duração suficientes para que fosse obtido um volume significativo de informação, a fim de propiciar uma sustentação adequada a esta dissertação.

É importante frisar que a justificativa do uso de entrevista em profundidade está na convicção de que as pessoas envolvidas em um fenômeno têm pontos de vista ou opiniões que só podem ser descobertas por meio da pesquisa qualitativa. Portanto, o que importa é a qualidade das informações, não o número de entrevistados ou ainda o número de estudos de caso (RICHARDSON, 1999).

Descrita a forma de coleta de dados, é conveniente destacar as técnicas, bem como os procedimentos utilizados para a análise dos dados obtidos, o que é feito a seguir.

\subsubsection{Técnicas e procedimentos para análise de dados}

Evidentemente, da mesma forma que a coleta de dados necessita ter um padrão e uma forma de execução definidos, a etapa de análise também carece dos mesmos. Segundo Lakatos e Markoni (2010, p. 152), "mesmo com dados válidos, é a eficácia da análise e da interpretação que determinará o valor da pesquisa”. Dessa 
forma, trata-se de uma etapa crucial para que a presente dissertação consiga proporcionar a contribuição acadêmica almejada.

Assim, a técnica de análise e tratamento dos dados escolhida foi a análise de conteúdo que, segundo Gil (2009), permite a descriminação do conteúdo manifesto e latente.

Essa escolha foi realizada com base na convergência entre o objetivo desta dissertação e a técnica de análise de conteúdo. Segundo Richardson (1999), existem três objetivos possíveis para a análise de conteúdo:

- Analisar as caraterísticas de um texto (mensagem) sem referência às intenções do emissor ou aos efeitos da mensagem sobre o receptor;

- Analisar as causas antecedentes de uma mensagem, procurando conhecer as suas condições de produção;

- Analisar os efeitos da comunicação para estabelecer a influência social da mensagem.

Dentre eles, o primeiro objetivo foi definido como foco para a análise de conteúdo do presente estudo, pois o intuito é comparar mensagens provenientes de duas ou mais fontes (estudos de caso e/ou entrevistados), identificando e analisando as características dos discursos.

A análise de conteúdo é particularmente utilizada para estudar material do tipo qualitativo, portanto, adequada à presente pesquisa. Sendo assim, é necessário que haja a "realização de uma primeira leitura para organizar as ideias para que posteriormente os elementos e as regras que as determinam possam ser melhor analisados" (RICHARDSON, 1999, p. 224).

Ainda segundo o autor, tal técnica tem a finalidade de possibilitar uma melhor compreensão de um discurso, bem como o aprofundamento do entendimento de suas características (gramaticais, fonológicas, cognitivas, ideológicas) para, dessa forma, extrair informações importantes.

Complementando, Richardson (1999, p. 223) explica que "a análise de conteúdo é uma técnica de pesquisa que tem como características metodológicas a objetividade, sistematização e inferência", descritas da seguinte forma:

- OBJETIVIDADE

Refere-se à explicitação das regras e dos procedimentos utilizados em cada etapa da análise de conteúdo (que categorias usar, como distinguir categorias, quais critérios utilizar para registrar e codificar o conteúdo). 
A objetividade implica que essas descrições se baseiem em um conjunto de normas que minimizem a possibilidade de que os resultados sejam mais um reflexo da subjetividade do pesquisador do que uma análise de conteúdo de determinado documento.

Dessa forma, trata-se de um fator importante para que de fato o pesquisador tenha uma postura o mais próxima possível da neutralidade na análise dos dados obtidos.

\title{
- SISTEMATIZAÇÃO
}

Refere-se à inclusão ou exclusão do conteúdo ou categorias de um texto de acordo com regras consistentes e sistemáticas. Isso significa que, para testar diversas hipóteses, o pesquisador deve analisar todo o material disponível, tanto aquele que apoia as suas hipóteses quanto os que não as apoiam.

- INFERÊNCIA

Richardson (1999, p. 224) afirma que essa característica "refere-se à operação pela qual se aceita uma proposição em virtude de sua relação com outras proposições já aceitas como verdadeiras".

$\mathrm{Na}$ presente dissertação, tal inferência foi realizada sobre as proposições mencionadas no tópico 3.1.2 Proposições de pesquisa.

Tendo ciência da importância de que a análise de conteúdo tenha as características mencionadas, Gil (2009, p. 89) explica:

\begin{abstract}
A análise de conteúdo desenvolve-se em três fases. A primeira é a pré-análise, onde se procede à escolha dos documentos, à formulação de hipóteses e à preparação do material para análise. A segunda é a exploração do material, que envolve a escolha das unidades, a enumeração e a classificação. A terceira etapa, por fim, é constituída pelo tratamento, inferência e interpretação dos dados.
\end{abstract}

- PRÉ-ANÁLISE:

Com o intuito de organizar a análise dos dados, nessa fase é escolhido o material para análise, formulação de hipóteses e a elaboração de indicadores para a interpretação do resultado (RICHARDSON, 1999). Após esta escolha, Bardin (2011) recomenda a realização de duas atividades: 
I - Leitura Superficial do Material (leitura "flutuante")

Trata-se da leitura que permite um primeiro contato com o material para conhecer a estrutura e ter as primeiras impressões em relação à mensagem dos documentos, possibilitando o reconhecimento dos conceitos mais utilizados.

II - Escolha dos documentos

Após a formulação do problema e dos objetivos de pesquisa, o pesquisador recolhe documentos que podem oferecer as informações necessárias ao estudo. Nesta pesquisa, estes foram os relatos advindos das entrevistas semiestruturadas realizadas no estudo multicaso, além dos arquivos fornecidos pelas empresas participantes. Vale ressaltar que a escolha dos documentos a serem analisados passou por uma amostragem que segue quatro critérios.

- Exaustividade:

Diz respeito à busca de todo material passível de utilização e que pode contribuir enquanto fonte de informação pertinente ao tema estudado.

- Representatividade:

Salienta a importância da amostra documental, de fato, representar fielmente os documentos que compõem o universo de pesquisa. Essa representatividade fidedigna é um dos fatores que possibilita, ou não, a generalização dos resultados encontrados após a análise.

- Homogeneidade:

Os documentos selecionados devem respeitar os critérios definidos para a pesquisa, de forma que estejam alinhados com as diretrizes definidas pelo trabalho acadêmico.

Adequação (pertinência):

Ressalta que os documentos selecionados devem proporcionar a informação adequada para que sejam atingidos os objetivos da pesquisa.

- ANÁLISE DO MATERIAL (EXPLORAÇÃO DO MATERIAL)

Essa fase consiste essencialmente nas atividades de codificação, categorização e quantificação da informação.

- tRATAMENTO dOS RESULTADOS

Nesta etapa, a análise de conteúdo trabalha sobre a forma de analisar ou tratar o material coletado, buscando codificar, ou seja, transformar os dados, agrupando-os em unidades ou categorias que permitam melhor representação e entendimento. 
Para o presente trabalho foi definido que esse agrupamento de informações ocorre através da categorização por temas ou análise temática. A análise consiste em "isolar temas de um texto (dados das entrevistas ou documentos) e extrair as partes utilizáveis, de acordo com o problema pesquisado, para permitir sua comparação com outros textos escolhidos” (RICHARDSON, 1999, p. 233).

Segundo Bardin (2011, p. 223), a análise temática "por meio de um sistema de categorias aplica uma teoria (corpo de hipóteses em função de um quadro de referência) ao material". Tal teoria é descrita no capítulo 2 - Referencial Teórico, bem como nas variáveis definidas para o estudo (tópico 3.1.3).

Como a pesquisa abrange tanto informações provenientes de comunicação oral como escrita, além da análise de conteúdo, será realizada também uma análise documental das informações obtidas em relatórios e demais registros físicos do fenômeno estudado.

Explicando esse conceito, Bardin (2011, p. 51) comenta que a análise documental é "uma operação ou um conjunto de operações visando representar o conteúdo de um documento sob uma forma diferente da original, a fim de facilitar a sua consulta e referenciação".

Complementando, a análise documental pode ser definida como "a observação que tem como objeto não os fenômenos sociais, quando e como se produzem, mas as manifestações que registram esses fenômenos e as ideias elaboradas a partir dele" (RICHARDSON, 1999, p. 228). Dessa forma, fazem parte dessa análise objetos, documentos fotográficos, cinematográficos e fonográficos, entre outros.

Esse tipo de análise pode, segundo Lakatos e Marconi (2010), ser realizada no momento em que o fato ou fenômeno ocorre, ou depois, de forma que em ambos os casos essa técnica de análise de dados mostra-se como uma eficiente fonte para a geração de informações que contribuam significativamente para a pesquisa.

Em resumo, o tratamento, a inferência e interpretação dos dados ocorreu, inicialmente, através da comparação dos mesmos com as proposições teóricas identificadas na revisão de literatura sobre o tema abordado.

Para facilitar tal comparação foram criados modos de apresentação em quadros, tornando mais prática a visualização e compreensão dos dados. 
Realizadas tais comparações, a pesquisa busca identificar a ocorrência de fatos ou reflexos não identificados em estudos anteriores, gerando uma contribuição acadêmica.

Para finalizar, foram comparadas as análises dos dados de cada estudo de caso com o intuito de identificar informações que venham a gerar uma maior profundidade e riqueza de informações.

Considerados os pontos referentes ao protocolo de pesquisa, é conveniente fazer uma abordagem ao método de estudo de caso.

\subsection{O MÉTODO DE ESTUDO DE CASO}

Esta seção explica questões importantes sobre o método de estudo definido para a presente pesquisa. As próximas páginas versam sobre o método estudo de caso - a sua definição, as críticas existentes sobre o mesmo, métodos de avaliação da sua qualidade, dentre outros aspectos relevantes para uma boa compreensão desse método.

\subsubsection{Introdução ao método estudo de caso}

Durante muito tempo, o estudo de caso foi encarado como procedimento pouco rigoroso, que serviria apenas para estudos de natureza exploratória. Atualmente, porém, é visto como o delineamento mais adequado para a investigação de um fenômeno contemporâneo dentro de seu contexto real, onde os limites entre o fenômeno e o contexto não são claramente percebidos (YIN, 2009).

Complementando essa ideia, Gil (2009. p. 55) afirma que:

[...] os propósitos do estudo de caso não são os de proporcionar o conhecimento preciso das características de uma população, mas sim o de proporcionar uma visão global do problema ou de identificar possíveis fatores que influenciam ou são por ele influenciados.

Sobre esse mesmo tema, Vieira $(1991$, p. 16) salienta que "[...] tais casos, quando devidamente documentados e propriamente analisados, constituem valiosa fonte de informação". Baseado nas afirmações acima é que foi definida a escolha do 
estudo de caso como o método de pesquisa adequado para a análise do tema deste trabalho acadêmico.

Diante de tais considerações é necessário que seja plenamente entendido o conceito do método estudo de caso, explicação que vem descrita nos próximos tópicos desta seção.

\subsubsection{Definição do método}

Diversos autores fazem considerações sobre a definição do método de pesquisa estudo de caso, que pode contribuir com o conhecimento de fenômenos individuais, grupais, organizacionais, sociais e políticos, além de permitir que o pesquisador retenha características holísticas e significativas dos eventos da vida real (YIN, 2009).

Complementando essa definição, Gil (2009, p. 54) salienta que:

O estudo de caso é caracterizado pelo estudo profundo e exaustivo de um ou de poucos objetos, de maneira que permita seu amplo e detalhado conhecimento, tarefa praticamente impossível mediante os outros delineamentos considerados.

Dessa forma, pode-se classificar este como sendo um método válido e adequado, considerando-se os objetivos propostos.

\subsubsection{Críticas em relação ao método estudo de caso}

Além de destacar os pontos fortes do método de pesquisa adotado, é conveniente discutir as suas limitações.

É comum o método de estudo de caso ser visto pejorativamente por diversos pesquisadores, provavelmente pela preocupação com a falta de rigor justificada pela reduzida gama de textos metodológicos que abordam os procedimentos específicos a serem seguidos, diferentemente de outros métodos mais amplamente estudados quanto às orientações metodológicas para aplicação dos mesmos (YIN, 2009).

Outro fator que depõe contra o seu uso ou contrário a sua aplicação / validade é a pouca base gerada para generalização científica, entretanto esse questionamento pode ser feito com relação ao experimento, por exemplo, já que a 
execução do mesmo uma única vez não possibilita a generalização, que pede um conjunto de experimentos múltiplos.

Contudo, Yin (2009) afirma que bons estudos de caso são difíceis, mas é possível de ser realizado quando atinge a profundidade necessária para explicar o fenômeno estudado.

\subsubsection{Critérios para avaliação da qualidade dos projetos de pesquisa}

Respondendo às críticas ao método de estudo de caso, existem alguns critérios que caracterizam se determinado estudo é ou não de qualidade, como fidedignidade, fidelidade, credibilidade e conformidade dos dados.

Para diagnosticar como tais critérios ocorrem, Yin (2009) aponta quatro testes comuns a todos os métodos da ciência social:

- Validade do constructo:

Refere-se à identificação das medidas operacionais corretas para os conceitos estudados;

- Validade interna:

Esse teste é válido somente para estudos exploratórios ou causais e não para estudos descritivos. Explicando o conceito, ele busca o estabelecimento de uma relação causal pela qual se acredita que determinadas condições levem a outras condições;

- Validade externa:

É a definição da amplitude para o qual as descobertas e resultados da pesquisa podem ser generalizados;

- Confiabilidade:

É compreendida como sendo a demonstração de que as operações de um estudo como, por exemplo, os procedimentos utilizados na coleta de dados podem ser replicados e assim obter os mesmos resultados.

Dentre os quatro testes acima mencionados, considera-se aplicáveis ao estudo multicasos realizado apenas o primeiro, pelo caráter descritivo da pesquisa, e o terceiro, que está alinhado à definição do limite da extrapolação dos resultados aqui identificados. 


\subsection{ETAPAS DA PESQUISA}

A presente pesquisa é subdivida em seis etapas, cuja sequência é ilustrada a seguir com a Figura 10.

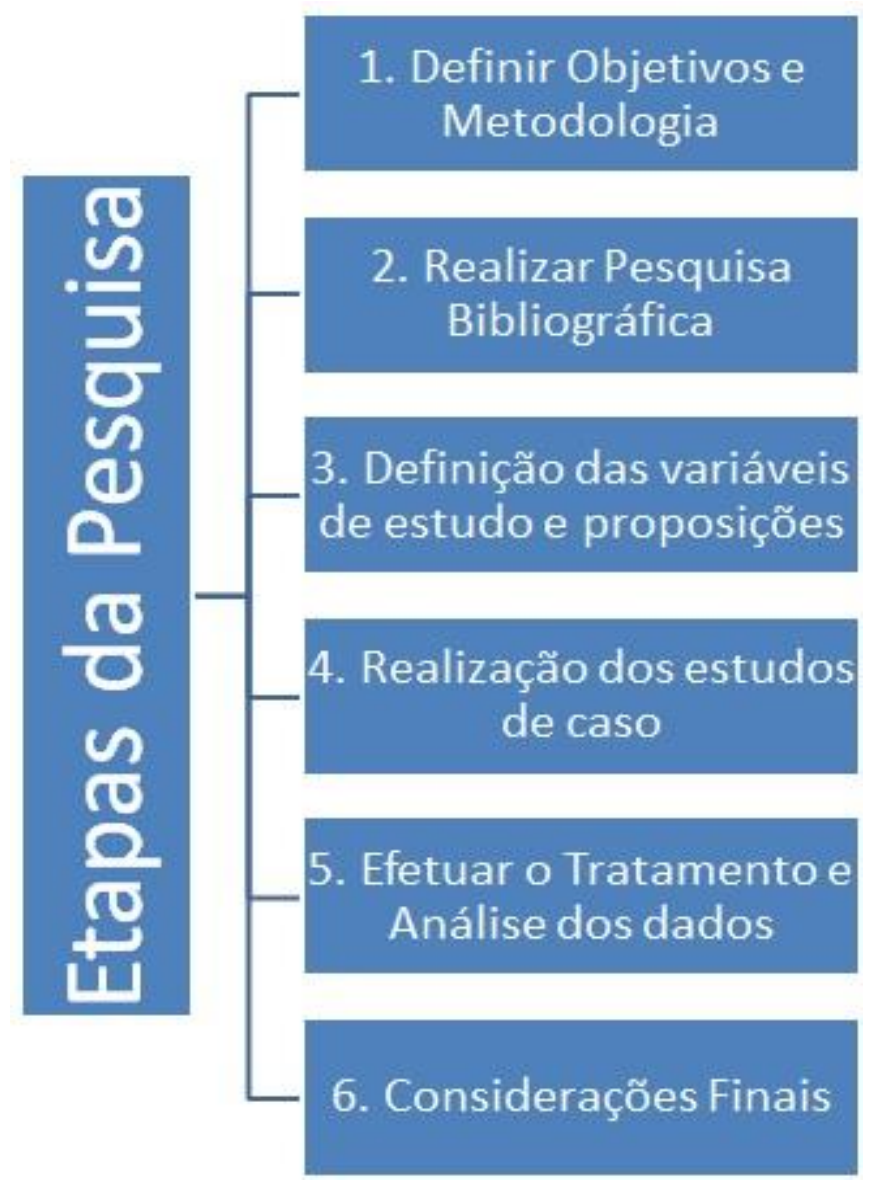

Figura 10 - Resumo das etapas da pesquisa.

3.5 RESUMO DOS PROCEDIMENTOS METODOLÓGICOS

Com o intuito de facilitar a visualização foi elaborado o Quadro 4, que resume os procedimentos metodológicos adotados na presente dissertação.

\begin{tabular}{|c|l|}
\hline \multicolumn{2}{|c|}{ Resumo - Procedimentos Metodológicos } \\
\hline Tipo de Pesquisa & Aplicada Descritiva \\
\hline Caráter da Pesquisa & Qualitativa \\
\hline Método de Pesquisa & Estudos multicasos (Protocolo de Pesquisa - Robert Yin) \\
\hline Natureza das Variáveis & Qualitativa \\
\hline Plano Amostral & $\begin{array}{l}\text { Organizações que implantaram o WMS } \\
\text { Desenvolvedores da solução WMS }\end{array}$ \\
\hline \multirow{2}{*}{ Técnicas de Coleta de Dados } & $\begin{array}{l}\text { Entrevista semiestruturada } \\
\text { Observação não-participante } \\
\text { Análise documental }\end{array}$ \\
\hline Técnicas de Análise de Dados & $\begin{array}{l}\text { Análise de Conteúdo Categorial } \\
\text { Análise Temática }\end{array}$ \\
\hline
\end{tabular}

Quadro 4 - Resumo dos procedimentos metodológicos. 


\section{ESTUDOS DE CASO}

Além da revisão bibliográfica sobre o tema, esta dissertação também busca coletar e analisar informações provenientes do mercado. Essa investigação acadêmica abrange a realização de entrevistas e observação não-participante em empresas que trabalham diariamente com o desenvolvimento, a implantação e utilização do WMS. Estas organizações subdividem-se em dois grupos:

- Empresas desenvolvedoras do software;

- Empresas que fazem uso do WMS em suas operações.

A seguir são apresentadas tais categorias e os estudos de caso.

\subsection{DESENVOLVEDORES DO SOFTWARE WMS}

Os principais pontos abordados no estudo deste grupo de empresas são as novas funcionalidades e benefícios que o WMS pode oferecer considerando-se o que há disponível no mercado e, dessa forma, gerar um arcabouço de informações que pode auxiliar empresas interessadas em adotar esse sistema de gestão a compreender melhor as possibilidades operacionais, dificuldades de implantação e benefícios proporcionados pelo WMS.

Nesta categoria, os estudos de caso foram realizados nas empresas PC Sistemas e Sythex.

\subsubsection{PC Sistemas}

A PC Sistemas é uma organização especializada no desenvolvimento de sistemas para o aprimoramento da operação logística na cadeia de suprimentos. A empresa foi fundada no ano de 1986 em Belo Horizonte (MG), entretanto atualmente possui unidades nas cidades de Goiânia, São Paulo, Rio de Janeiro, Joinville, Porto Alegre, Fortaleza, Recife e Belém nas quais atuam aproximadamente 500 colaboradores. Há 26 anos no mercado, a empresa atende cerca de $34 \%$ dos maiores atacadistas e distribuidores do Brasil e atua em 27 estados brasileiros, incluindo o Distrito Federal. Foi neste contexto que em 2012 a companhia atingiu o faturamento de 52 milhões de reais. 
O sistema desenvolvido pela empresa é denominado WinThor, um ERP que auxilia no aprimoramento operacional em vários seguimentos, dentre eles 0 atacado/distribuidor, materiais de construção, autopeças, frios, medicamentos e indústria.

O software disponibiliza soluções nos módulos Call Center, Contábil, Controle Patrimonial, Customer Relationship Management (CRM), Rádio Frequência (RF), Licitação, Myshop, Planejamento Estratégico, Mobile, My Frota, My BI e WMS. A Figura 11 ilustra a interface do sistema.

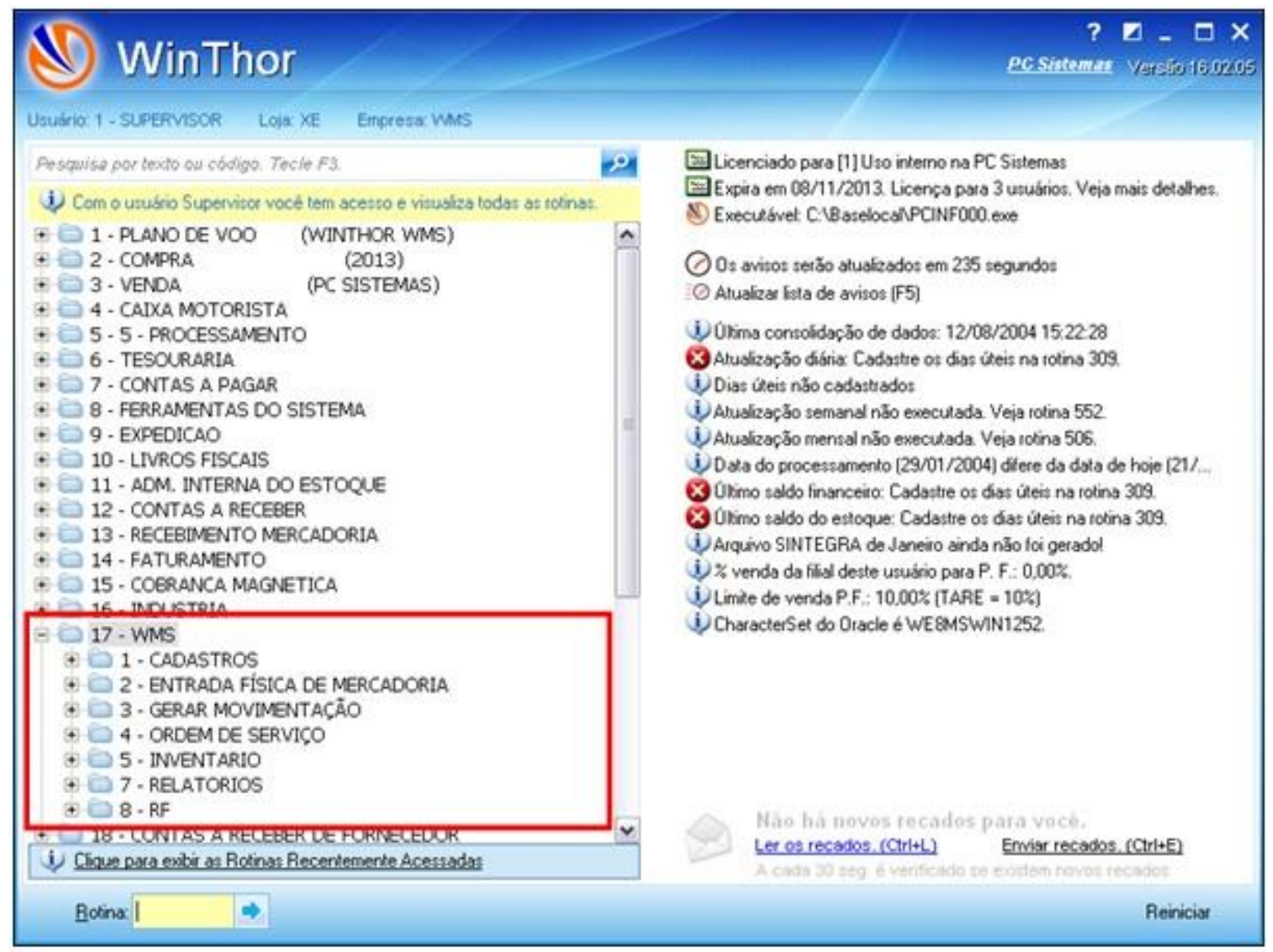

Figura 11 - Winthor.

As informações discutidas e analisadas a seguir foram obtidas através de entrevista realizada em 30 de agosto de 2012 com o engenheiro de produção responsável pela manutenção e evolução do módulo WMS a nível nacional.

Com base na entrevista, foi possível identificar um número considerável de empresas que passaram a adotar o WMS nos últimos anos. Segundo o entrevistado, "quem conhece em profundidade o sistema se destaca no mercado, sendo que um dos pontos fundamentais é o entendimento das variações de processos que ele oferece". 
Ainda de acordo com ele, apesar de ser uma ferramenta que evidentemente contribui para que se obtenha maior eficiência operacional, estima-se que dentre as funcionalidades e opções de processos que o software disponibiliza, a maior parte dos clientes utiliza no máximo $50 \%$ dos recursos que o sistema oferece. Dos 150 clientes atualmente usuários do WinThor, não mais do que 10 utilizam acima de 50\% dos recursos do sistema.

Uma possível causa para essa situação é a suposta falta de visão estratégica por parte das empresas, já que na sua maior parte são reativas às demandas e necessidades do mercado, deixando de buscar as melhores práticas continuamente. Estas empresas contratantes que adquirem o sistema, o utilizam para melhorar a operação em alguns aspectos específicos identificados anteriormente como problemas e não vislumbram soluções que possam gerar outros ganhos operacionais.

A despeito deste contexto, antes de obter benefícios ou aprimorar a eficiência na gestão da armazenagem, é necessário que as organizações superem as dificuldades e barreiras inerentes ao processo de implantação do WMS. Evidentemente estas são diferenciadas dependendo do tamanho (micro, pequeno, médio ou grande porte) e grau de maturidade da empresa. Para as de micro e pequeno porte, a maior dificuldade inicial está na questão financeira, já que é necessário um desembolso significativo para a aquisição e implantação do software.

Para tornar mais claro, segundo dados da PC Sistemas, a maioria dos clientes tem um faturamento entre 300 e 500 mil reais por dia, trabalhando com um mix de produtos de 2.000 a 6.000 itens em armazéns que variam em média entre $4.000 \mathrm{~m}^{2}$ e $6.000 \mathrm{~m}^{2}$. O valor de aquisição do sistema por estes clientes é definido com base no número de usuários, existindo uma correlação positiva entre o número destes e o valor final a ser pago. Somando-se a tecnologia a ser adquirida (sistema, antenas, coletores de código de barras) e o investimento em consultoria (preparação e treinamento), o montante investido facilmente chega aos $R \$ 200.000,00$.

Com o desenvolvimento das operações e a maior exigência do cliente final quanto ao nível de serviço, foram sendo criadas formas para tornar a logística de armazenagem mais assertiva e eficaz. Uma das formas de atingir tais melhorias é através da aplicação das funcionalidades oferecidas pelo WMS, sistema que trabalha sobre três principais processos: entradas, administração interna e saídas. 
As entradas correspondem ao processo de recebimento de mercadorias, sejam elas provenientes de fornecedores, transferências ou devoluções do cliente. Inicialmente as NFs da carga recebida são introduzidas no sistema Whintor e a partir deste momento o WMS realiza a conferência cega da carga e o endereçamento automático dos produtos, feito com base em informações cadastradas nos sistemas, referente aos endereços e aos produtos, determinando o melhor local para se alocar a mercadoria.

Caso no momento do recebimento toda a capacidade de armazenamento esteja sendo utilizada, o sistema cria um endereço virtual no qual os produtos ficam aguardando a liberação de espaço físico para serem estocados, sendo a mercadoria encaminhada a algum local disponível, como um corredor, por exemplo. Quando esta liberação ocorre, automaticamente o WMS gera uma ordem de serviço para realizar as movimentações necessárias.

O segundo processo gerido pelo software, a administração interna do armazém, envolve o cadastro dos produtos e endereços, execução do reabastecimento da área de picking (corretivo e preventivo), realização de inventário, Cross Docking, montagem de kits (como a cesta básica) e elaboração de relatórios gerenciais.

Quanto ao cadastro, existe a possibilidade do fornecedor enviar produtos com código de barras EAN ou DUN. Entretanto, o sistema disponibiliza a opção de cadastramento de ambos para o mesmo produto, sendo assim, no momento do recebimento, independentemente do tipo de código de barras utilizado, o WMS passa a reconhecer e identificar corretamente o item lido pelo coletor. Nessa atividade também são registrados no sistema os endereços disponíveis para armazenagem, cadastrando as restrições físicas, segregação do estoque por família de produtos ou ainda condições de armazenagem específicas de cada área do armazém (temperatura e umidade).

Realizada a estocagem dos produtos, o sistema indica automaticamente a necessidade de reabastecimento dos endereços de picking sempre que este atingir o nível mínimo cadastrado no WMS. Esta situação pode ocorrer de forma preventiva, quando o software informa a necessidade de reposição, pois o endereço atingiu o seu estoque mínimo, ou ainda de forma corretiva, quando esta ação é demandada a partir da retirada dos itens para a separação dos pedidos, evitando paralisações na separação de pedidos, o que incrementa a eficiência operacional. 
Ainda quanto à administração interna, para que seja possível a realização do inventário, o WMS somente possibilita a sua execução quando as movimentações pendentes de entrada e saída dos endereços estiverem concluídas ou canceladas. Neste contexto, existe a possibilidade de não se realizar a contagem de todos os produtos em estoque, mas sim a contagem por critérios convenientes, como por produto, por endereço, por fornecedor ou ainda por shelf-life. Antes da contagem, também são definidas as informações que farão parte do inventário, como quantidade no endereço, a data de validade e/ou o lote do item.

A partir das escolhas referentes a estes aspectos, os endereços são bloqueados durante a execução do inventário a fim de inibir a ocorrência de divergências.

Segundo o entrevistado, pelo fato do segmento atacadista ter como características a compra e venda de produtos, não envolvendo a fabricação, o diferencial do mercado passa a estar relacionado à prestação de serviço. Evidentemente, neste processo logístico, a operação de separação de pedidos reflete significativamente no nível de serviço prestado ao cliente, bem como na diferenciação da empresa em relação ao mercado em que atua.

O último processo, a saída de mercadoria, envolve a separação e conferência dos produtos antes do embarque. Nesta etapa, a segregação dos itens pode ser realizada de 17 formas:

- Separação por pedido;

- Separação por pedido flow-rack;

- Separação por pedido caixa fechada;

- Separação por pedido por peso e volume;

- Separação por grupo de estação;

- Separação por notas fiscais;

- Separação por carregamento;

- Separação por carregamento/rua;

- Separação por carregamento/lado da rua;

- Separação por carregamento/rua/praça;

- Separação por praça;

- Separação por cidade;

- Separação paletizada com produtos fracionados por pedido; 
- Separação paletizada com produtos fracionados por palete;

- Separação paletizada com produtos fracionados por depósito;

- Separação paletizada com produtos fracionados por equipamento transitável;

- Separação de palete fechado direto do pulmão para o box.

A Figura 12 ilustra a tela na qual é possível definir qual dessas opções é a mais adequada para a operação do cliente.

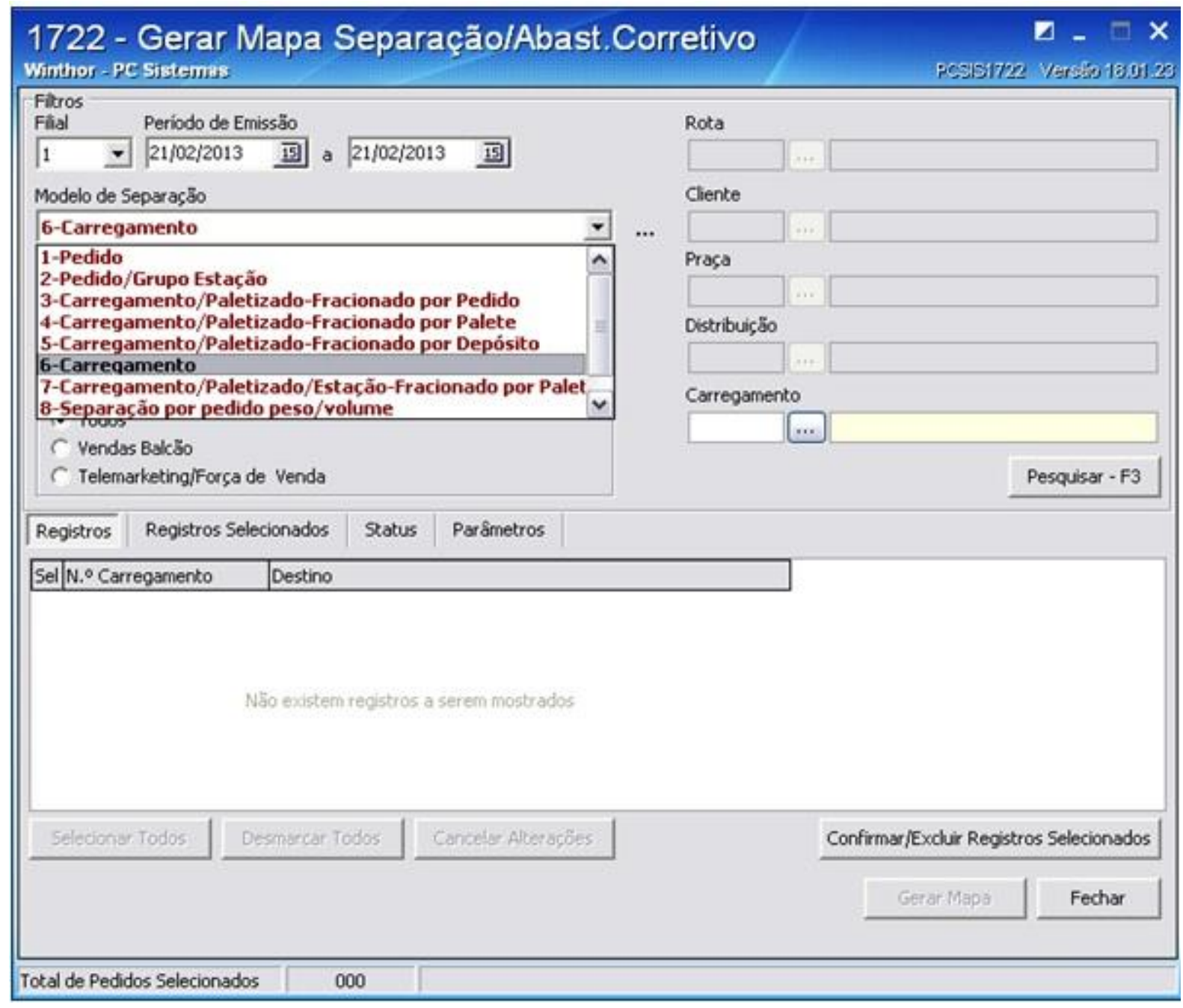

Figura 12 - Winthor, Tela de separação de produtos.

A fim de controlar e monitorar tais processos, o WMS oferece diversos relatórios gerenciais que contribuem para uma tomada de decisão mais assertiva em relação à operação. Dentre eles, pode-se citar: o controle de produtividade, relatório do vencimento dos produtos (lista crítica), monitoramento das ordens de serviço e sugestão de alteração da capacidade de armazenagem do endereço de picking.

Todas as funcionalidades mencionadas acima são liberadas ao colaborador pela definição de perfis, ou seja, o operador que atua na rotina de recebimento não 
tem acesso às aplicações inerentes à separação do pedido, aplicando-se o mesmo raciocínio para as demais funções. Dessa forma, não possibilitando a execução de determinadas ordens de serviço por pessoas não autorizadas à realização das mesmas.

Mostrando de forma mais sucinta a descrição acima, tem-se o Quadro 5.

\begin{tabular}{|c|l|}
\hline Processo & \multicolumn{1}{|c|}{ Funcionalidade } \\
\hline \multirow{2}{*}{ Entradas } & Conferência de carga \\
\cline { 2 - 2 } & Endereçamento automático (Curva ABC e restrições físicas) \\
\hline \multirow{4}{*}{ Administração Interna } & Cadastro de produtos e endereços \\
\cline { 2 - 2 } & Ressuprimento automático do picking \\
\cline { 2 - 2 } & Realização de Cross Docking \\
\cline { 2 - 2 } & Montagem de kits \\
\cline { 2 - 2 } & Realização de inventário \\
\cline { 2 - 2 } & Elaboração de relatórios gerenciais \\
\hline \multirow{2}{*}{ Saídas } & Separação de pedidos \\
\cline { 2 - 2 } & Conferência dos produtos separados \\
\hline
\end{tabular}

Quadro 5 - Resumo das funcionalidades do WMS PC Sistemas.

Para que tais funcionalidades possam ser utilizadas plenamente, recomendase que a empresa usuária do WMS execute um processo, uma sequência de atividades que auxilie na obtenção de maiores ganhos operacionais, segundo a PC Sistemas, essas atividades são:

1) Alinhar adequadamente as expectativas iniciais sobre o sistema com o que de fato este oferece;

2) Preparação Cultural: estar disposto a quebrar paradigmas quanto à forma de trabalho, pois o WMS traz mudanças fortes. Envolver desde a área operacional até a diretoria no projeto de implantação, explicando detalhadamente qual o objetivo, os percalços no caminho e a necessidade de colaboração entre todos os processos da organização. Realização de treinamentos antes, durante e após a implantação do sistema.

3) Foco e atenção no cadastro dos endereços (quantidades e restrições) e produtos;

4) Mapeamento dos processos e reorganização, caso seja necessário;

5) Implantação do WMS, acompanhamento e orientação.

O tempo médio para a conclusão do projeto de implementação do WMS varia de quatro meses a um ano. Entretanto, algumas organizações, por não darem a devida atenção às etapas do processo de implantação, chegam a demorar dois anos para obter resultados significativos e ter uma operação eficiente. 
Relacionadas as dificuldades referentes à implantação, as funcionalidades oferecidas pelo software da PC Sistemas e a sugestão de processo de implantação, é conveniente que sejam abordadas as tendências de evolução para o WMS, que envolvem três tópicos, segundo o entrevistado:

- Indicadores de desempenho para tomada de decisão: desenvolvimento de novos indicadores que auxiliem ainda mais os gestores a tomarem decisões assertivas com base em relatórios operacionais de fácil visualização;

- Mobilidade: vinculação do sistema com smartphones, tablets e demais ferramentas que a tecnologia da informação venha a oferecer para o acompanhamento da operação mesmo fora da empresa;

- RFID: integrar o sistema WMS com a tecnologia de identificação por rádio frequência.

Complementando as informações provenientes da PC Sistemas e no intuito de evitar o viés de apenas uma fonte de informação nesta categoria, a seguir é descrito o segundo estudo de caso envolvendo uma empresa desenvolvedora do software WMS, a Sythex.

\subsubsection{Sythex}

Fundada em 1994, a Sythex - Tecnologia em Sistemas atua como desenvolvedora de softwares de gestão, trabalhando com o ERP, TMS e WMS, sendo este último a especialidade da empresa e também o foco em análise.

A empresa opera em quatro segmentos: atacadista/distribuidor, indústria, operadores logísticos e varejistas (considerando-se também o e-commerce), atendendo ao mercado com 70 colaboradores, distribuídos em duas unidades localizadas nas cidades de Ribeirão Preto e São Paulo.

Denotando seu reconhecimento no mercado, dentre os clientes de maior representatividade pode-se destacar o Super Muffato, Centauro, Netshoes, FEMSA (Indústria do grupo Coca-Cola), Volvo, Hyundai e Braspress (maior transportadora de encomendas da América Latina).

Conforme entrevista realizada com o responsável pelo desenvolvimento e implantações do sistema WMS, no primeiro contato, geralmente os clientes procuram a Sythex com um conhecimento razoável sobre a ferramenta, uma ideia geral das funcionalidades do sistema, entretanto sem considerável profundidade. É 
normalmente neste contexto que se inicia o processo de implantação do sistema, com duração média de três a quatro meses, sendo que há um acompanhamento em tempo integral de um consultor na empresa durante o primeiro mês.

O tempo decorrente desde o início da implantação até o seu término é diretamente influenciado pela eficiência do cliente na definição dos seus processos de negócio, ou seja, na elaboração de procedimentos padrão relatando a sequência de atividades e a forma de executá-las em cada processo sem comprometer ou prejudicar outras áreas. Havendo, assim, uma correlação positiva entre a organização e definição dos processos de negócio e a facilidade na implantação do WMS.

Além disso, existem também outras questões importantes para que tal projeto seja realizado com sucesso, como o apoio da diretoria, mudança cultural e um cadastramento de produtos realizado de forma correta (sem duplicidade de informações ou equívocos de digitação), fatores explicados a seguir.

Segundo o entrevistado, não há como se iniciar um projeto de implantação do WMS sem o apoio da diretoria, que significa a força motriz para a conclusão da adoção do sistema, já que contribui consideravelmente para a mudança e adaptação da cultura organizacional.

Iniciada a implantação, destaca-se como uma das maiores dificuldades para a empresa a realização do cadastro correto dos produtos. É frequente a ocorrência de erros de digitação nos códigos de barras dos produtos ou ainda em outras informações, falhas detectadas posteriormente no dia a dia da operação ou ainda no inventário físico quando as divergências de estoque são identificadas. Dessa forma, esta questão mostra-se como sendo o maior fator influenciador para as suspensões ou atrasos na conclusão do projeto WMS.

O sistema desenvolvido pela Sythex trabalha por meio de interface com o ERP do cliente de forma a inibir a dicotomia de informações, mesmo quando este trabalha com diversas filiais.

Este software oferece uma quantidade considerável de funcionalidades, que, com o intuito de facilitar o entendimento e a análise, foram subdivididas por atividade, sendo elas: recebimento, armazenagem, separação de pedidos e relatórios gerenciais.

$\mathrm{Na}$ primeira atividade do processo da gestão da armazenagem, o recebimento, o WMS realiza o agendamento das cargas a serem recebidas, sendo 
elas provenientes de fornecedores, transferências ou ainda devoluções de clientes. Nas três situações, o sistema capta as notas fiscais assim que emitidas pelo fornecedor através da troca eletrônica de dados (EDI), interagindo com a cadeia de suprimentos.

Com base na programação de recebimento, o sistema realiza o cálculo dos recursos necessários para que seja possível atender a demanda de trabalho prevista. O cálculo é realizado com base nas informações cadastradas que indicam o tempo médio para recebimento de todos produtos, ao final sinalizando a necessidade de pessoal e maquinário para efetuar o desembarque agendado.

Havendo a necessidade é possível priorizar a descarga de determinado veículo a partir da autorização do gestor do armazém via sistema. O software ainda executa o controle de portaria no qual há o monitoramento em tempo real do status da agenda de recebimento, além do cadastro das informações dos veículos que chegam à empresa. Estando o veículo apto a ser descarregado, o WMS realiza a convocação ativa para a realização do recebimento, que é o envio de uma ordem de serviço aos coletores de código de barras dos operadores de empilhadeira e demais funcionários atuantes nesta atividade, sinalizando assim a demanda de serviço.

No momento do recebimento é realizada a conferência de todos os produtos através da leitura dos códigos de barras, caso seja identificada alguma divergência esta é acusada pelo sistema e são tomadas as providências necessárias.

Finalizado o recebimento, a mercadoria é movimentada internamente até a área de armazenagem de forma que seja sempre monitorado o FIFO ou First Expire, First Out (FEFO), bem como o shelf-life dos produtos. O endereçamento ocorre de forma automática considerando-se a Curva $A B C$ (atualizada automaticamente pelo WMS) e as restrições cadastradas no sistema, tais como as dimensões físicas dos endereços, segregação do armazém por família ou restrições de temperatura e umidade.

O WMS também contribui para a manutenção da organização do estoque e, para que haja o melhor aproveitamento do espaço disponível para armazenagem, ele analisa a fragmentação dos espaços e sugere a reorganização do estoque caso seja necessário.

O sistema ainda realiza o controle da área de picking, indicando a necessidade de ressuprimento automaticamente, além de segmentar os produtos com base no seu status (liberado, reservado, quarentena, avariado e bloqueado). 
Estando os produtos devidamente armazenados, o processo de separação de pedidos pode ocorrer de formas variadas oferecidas pelos sistema, como a utilização de convocação ativa, na qual o operador de empilhadeira ou o estoquista somente executa alguma movimentação a partir do momento em que aparece em seu coletor de código de barras a ordem de serviço liberada pelo colaborador responsável pelo WMS ou a separação de itens por onda, podendo a segregação das mercadorias ser realizada por nota fiscal, por cliente ou por rota, de acordo com a programação de embarque.

É com base nesta programação que o sistema, da mesma forma como ocorre no recebimento, realiza a previsão da necessidade de pessoal, máquinas e equipamentos. No decorrer da separação, o software indica ao operador o percurso lógico a ser seguido, minimizando assim a distância a ser percorrida e imprimindo maior velocidade à separação.

Ao término da segregação dos itens a serem embarcados, o WMS realiza uma conferência dupla na expedição - a primeira na própria separação dos pedidos quando estes são retirados da área de armazenagem e colocados nas docas de embarque e a segunda no ato do carregamento dos veículos no qual novamente são lidos os códigos de barra dos volumes e confirmado o embarque no veículo. Nesta etapa são cruzadas as informações da carga programada para embarque e dos produtos que foram bipados no coletor, havendo itens faltantes ou excedentes, a divergência é detectada pelo sistema e o operador toma as medidas corretivas necessárias.

Este processo pode estar integrado a novas tecnologias como a separação por voz (picking by voice), separação por luz (picking by light), o uso de esteiras que direcionam automaticamente os volumes para as docas de expedição ou ainda a utilização da tecnologia RFID, agilizando o processo e tornando a operação mais eficiente. Independentemente da tecnologia utilizada, todo o processo de separação é monitorado em tempo real.

Por fim, quanto às funcionalidades destinadas à gestão do armazém, existem diversos relatórios que dão suporte à tomada de decisão, com destaque: ocupação de estoque (visualização em 3D); produtividade por atividade (geral, recebimento, transferência, separação de pedidos), operador, equipe ou turno; detalhamento do inventário; distribuição automática de tarefas pendentes e o resumo de todas as operações. 
O monitoramento da produtividade é realizado com base na parametrização dos tempos médios por tarefa, sendo cadastradas a distância a ser percorrida, o tipo de equipamento utilizado e a família de produtos movimentada. Estas informações cadastradas são comparadas com os registros das operações executadas por cada colaborador, sendo a produtividade mensurada por intermédio do cruzamento de dados.

O conjunto das funcionalidades explicadas oferece o benefício de se obter uma operação mais eficiente, na qual a ocorrência de falhas e ociosidade são minimizadas, enquanto há uma otimização da velocidade e controle operacional, gerando um melhor nível de serviço ao cliente.

Como cada empresa trabalha a sua maneira, é comum a diferente utilização do sistema por parte dos clientes. Normalmente, empresas de grande porte tendem a utilizar uma maior parcela dos recursos do WMS por terem uma maior estrutura, bem como melhor organização dos processos ou o próprio conhecimento da ferramenta. Já empresas de menor porte tendem a fazer uso de operações básicas como o endereçamento, controle de lotes e o ressuprimento automático do picking. Evidentemente não se trata de uma regra, o fato da empresa ter um grande porte não é um pré-requisito para que a organização utilize boa parte das funcionalidades do WMS, entretanto a existência de mão-de-obra disponível e capacitada para o bom uso da ferramenta é um fator determinante.

Quanto às tendências de desenvolvimento do sistema WMS para o futuro, os pontos destacados pela Sythex foram o investimento no desenvolvimento de relatórios personalizados, que possam auxiliar na melhoria da produtividade e otimização dos processos e a evolução da aplicabilidade da tecnologia RFID.

Realizada a apresentação dos estudos de caso em desenvolvedores do software WMS, a seção a seguir descreve as empresas participantes da pesquisa que são usuárias do sistema.

\subsection{ORGANIZAÇÕES USUÁRIAS DO SISTEMA WMS}

Complementando a visão dos desenvolvedores de software, os estudos multicasos objetivam agregar a visão do dia a dia operacional de três organizações que fazem uso do WMS, possibilitando a identificação das barreiras para a utilização, bem como os benefícios provenientes da ferramenta. 
A escolha das organizações a serem analisadas foi definida por conveniência, conforme disponibilidade e interesse das mesmas em contribuir com a pesquisa. $O$ número destes estudos foi definido de acordo com a profundidade dos casos disponíveis, de forma a fornecer informações suficientes que possibilitem a definição de algumas considerações acerca do tema.

\subsubsection{Distribuidora X}

A Distribuidora $X$ é sediada na cidade de Ribeirão Preto, fatura aproximadamente três milhões de reais ao mês e é composta por 150 funcionários, sendo 20 deles atuantes na área de logística.

As atividades operacionais inerentes a esta área são supervisionadas pelo gerente de logística, sendo este o principal contato para a realização do presente estudo de caso. Sob a sua responsabilidade está a gestão de aproximadamente 1.200 SKUs, com 30 dias de cobertura de estoque, o que evita o corte de pedidos pela falta de disponibilidade dos produtos.

Este mix de produtos é proveniente de 13 fornecedores, dentre os quais destacam-se Basilar, Johnson \& Johnson, Mate Leão e Santa Helena, empresas que trabalham com produtos como macarrão, biscoitos, produtos de higiene pessoal, chá, amendoim e paçoca. Vale ressaltar que todos estes itens têm em comum a característica de serem produtos classificados como "secos", ou seja, mercadorias que não necessitam de condições especiais de armazenamento e transporte como, por exemplo, o controle de temperatura e umidade.

Para a estocagem destes produtos, a empresa tem à disposição um armazém com $3.360 \mathrm{~m}^{2}$ de área e pé direito de $10 \mathrm{~m}$, no qual faz uso da armazenagem verticalizada por meio da estrutura porta-palets, proporcionando um total de 2.680 posições/palet, movimentadas por duas empilhadeiras elétricas.

Quanto à operação, são expedidas em média 350 cargas por mês, correspondendo à movimentação de 402.902 toneladas de produtos. Para gerir tal operação, a empresa usa o ERP (Sitel) e o WMS, este último fornecido pela empresa desenvolvedora de softwares Sythex - Tecnologia em Sistemas.

Recentemente a empresa identificou algumas dificuldades na gestão da armazenagem desde a acuracidade de estoque até $\mathrm{o}$ controle de lotes e monitoramento da eficiência operacional dos funcionários tanto no recebimento, 
como na expedição. Buscando soluções, em uma das visitas de um dos diretores a uma feira de logística, o projeto de implantação do WMS, em novembro de 2011, surgiu como uma possibilidade de solução para a gestão da logística interna.

No decorrer do processo de adoção do WMS, incorreram diversos percalços, destacando-se a questão cultural como principal dificuldade. Compreende-se este fator como sendo a resistência por parte dos colaboradores envolvidos na operação, a aversão quanto à nova forma de trabalho imposta pelo software. Segundo o gerente de logística, "inicialmente, todos diziam que não iria funcionar e que o sistema somente atrapalhava a operação. Para que o WMS funcione é necessário que haja uma conscientização de todos os funcionários, desde a diretoria até o operacional".

Mesmo tendo sido previamente realizado um treinamento dos colaboradores para esclarecer o que é a ferramenta WMS, as suas funcionalidades e os seus benefícios, houve ainda a incompreensão de alguns.

Nesse momento, a empresa pôde identificar que a implantação WMS não afeta apenas a rotina de trabalho dos colaboradores atuantes na área de gestão da armazenagem, mas sim a rotina de toda a empresa, já que os processos organizacionais são interligados, o que corrobora com o conceito de visão sistêmica, explicado por Chiavenato (2011). Foi tamanha a amplitude do conflito interno entre as áreas da empresa em decorrência dessa mudança que o projeto por pouco não foi abortado.

Por esse motivo, houve a contratação de uma consultoria que conduziu o mapeamento dos processos da organização, auxiliando, assim, no entendimento desses setores. Nesse processo, cada colaborador descreveu as atividades exercidas minuciosamente e as apresentaram em reunião geral, na qual foi possível identificar como a forma que realizam seus afazeres influencia a rotina das demais áreas de empresa, focando principalmente nos reflexos gerados para a operação do WMS.

Esse foi um passo fundamental para que os funcionários tomassem consciência da importância de que todos trabalhem de forma a não prejudicar outras áreas e assim contribuir para o sucesso do projeto. A partir deste ponto, cada colaborador compreendeu a forma adequada de trabalhar a fim de não gerar impactos negativos para a operação de armazenagem. 
Diante de tais dificuldades, para que o sistema efetivamente estivesse implantado e funcionando de forma linear foram necessários seis meses de adaptação. Entretanto, para a sua completa utilização, acredita-se que haja a necessidade de que se transcorra o prazo de aproximadamente um ano.

Dentre os benefícios provenientes do WMS, a empresa salienta a melhor organização do estoque, controle apurado de lotes (FIFO), rastreabilidade dos produtos, aprimoramento do controle de devoluções, bem como a minimização dos erros operacionais, melhoria da visibilidade e acuracidade de estoque. Todos esses fatores somados contribuíram de forma significativa para a melhoria do nível de serviço prestado ao cliente.

Com o controle operacional mais preciso, situações como a venda de produtos sem a real disponibilidade em estoque foram eliminadas. Pelo fato da empresa se enquadrar como um prestador de serviço, esta foi uma melhoria que the agregou maior confiabilidade e refletiu também no aumento da receita.

Tratando-se da questão operacional, foi analisado o processo de armazenagem como um todo, conforme ilustrado pela Figura 3. Iniciando-se pelo recebimento, as cargas provenientes dos fornecedores chegam à empresa "batidas", ou seja, não paletizadas. A gerência vê esta forma de trabalho como algo positivo, já que é possível montar o lastro do palet dentro das limitações físicas dos endereços de armazenagem disponíveis no momento. Além disto, é possível que $100 \%$ da carga seja conferida de forma "cega" (sem comparar o pedido com a descrição da nota fiscal). Este procedimento elimina a ocorrência de erros no recebimento, seja por divergência na quantidade ou no tipo do produto.

Além da melhoria do processo de recebimento, houve também aprimoramento do processo de separação de pedidos, destacado pela empresa como um dos principais benefícios do sistema WMS, já que através da maior eficiência obtida nesta atividade foi possível aumentar significativamente o volume diário de cargas expedidas, atendendo ao cliente com um prazo de entrega mais competitivo.

Analisando o antes e o depois do processo de separação, verificou-se que esta atividade era realizada de forma precária, "pelo olho" do separador - o colaborador recebia a ordem de separação e perdia um tempo considerável à procura do produto solicitado, já que a identificação do item correto era realizada pela visualização da mercadoria. Com a aplicação do WMS, o tempo de procura foi 
reduzido drasticamente, pois o sistema fornece o endereçamento, que indica a localização exata dos produtos a serem separados, aumentando a velocidade do processo em aproximadamente $80 \%$.

Outro fator que contribui para a atual organização da operação interna é a forma como a empresa lida com as devoluções, comumente consideradas um problema significativo para a gestão do estoque, e que foram aprimoradas após a implantação do WMS. Como em todo recebimento, a carga proveniente de devolução é "bipada" na íntegra pelo coletor de código de barras que informa todos os dados do item desde a identificação do produto até o lote e a sua validade. Com essas informações, o sistema indica através do endereçamento automático a área destino da mercadoria devolvida, podendo esta ser estocada na área de picking ou ainda na ala de produtos críticos, que são aqueles cujo prazo de validade está próximo e são somente expedidos após negociação realizada pela área comercial.

Em relação à questão acima, diariamente o WMS gera uma listagem de itens críticos acompanhada pela área comercial a fim de que sejam tomadas providências para o escoamento, minimizando a quantidade de produtos vencidos em estoque. A empresa chegou a ter um prejuízo mensal de aproximadamente $R \$ 15.000,00$ com a perda de produtos nestas condições, após a implantação do software este número caiu em $86,7 \%$ e atualmente a perda é de $\mathrm{R} \$ 2.000,00$ ao mês, considerando-se não somente as mercadorias vencidas, mas também os itens danificados e amassados.

Além das características descritas, identificou-se neste estudo de caso um benefício não mencionado na literatura consultada: a satisfação dos próprios colaboradores em trabalhar de forma mais organizada. Após as dificuldades iniciais, os mesmos funcionários que criticaram o sistema passaram a compreender melhor como ele funciona e a sentirem-se satisfeitos por ter uma operação mais eficiente, exigindo dos colegas de trabalho que executem suas atividades de forma a não prejudicar a operação.

É importante ressaltar que o suporte e apoio da direção e gerência desde o início do projeto influenciou diretamente para que os resultados descritos fossem alcançados.

Feitas tais considerações o Quadro 6 resume as informações provenientes do estudo de caso. 


\begin{tabular}{|c|l|c|}
\hline Indicador & \multicolumn{1}{|c|}{ Variável } & Distribuidora X \\
\hline \multirow{4}{*}{$\begin{array}{c}\text { Gestão de } \\
\text { Pessoas }\end{array}$} & Conhecimento do conceito WMS antes da implantação & Não \\
\cline { 2 - 3 } & Preparação e treinamento pré-implantação do WMS & Sim \\
\cline { 2 - 3 } & Mapeamento e alinhamento dos processos organizacionais & Sim \\
\cline { 2 - 3 } $\begin{array}{c}\text { Tecnologia da } \\
\text { Informação }\end{array}$ & Apoio da alta gerência & Sim \\
\hline \multirow{2}{*}{$\begin{array}{c}\text { Velocidade } \\
\text { operacional }\end{array}$} & Antequação às necessidades da operação & Sim \\
\cline { 2 - 3 } & Aumento da velocidade de recebimento & Sim \\
\cline { 2 - 3 } & Aumento da velocidade de separação de pedidos & Sim \\
\hline \multirow{5}{*}{$\begin{array}{c}\text { Controle da } \\
\text { operação }\end{array}$} & Programação e sequenciamento do recebimento operacionais & Sim \\
\cline { 2 - 3 } & Controle de portaria e pátio & Não utilizado \\
\cline { 2 - 3 } & Erros de conferência no recebimento & Não utilizado \\
\cline { 2 - 3 } & Melhor utilização do espaço disponível & Minimizados \\
\cline { 2 - 3 } & Melhor visualização do estoque & Sim \\
\cline { 2 - 3 } & Controle de lotes (rastreabilidade, FIFO) & Sim \\
\cline { 2 - 3 } & Gerenciamento de devoluções & Utilizado \\
\cline { 2 - 3 } & Programação e sequenciamento da separação de pedidos & Utilizado \\
\cline { 2 - 3 } & Erros na separação do pedido & Minimizado \\
\cline { 2 - 3 } & Erros de conferência no carregamento & Minimizados \\
\cline { 2 - 3 } & Priorização de atividades & Não utilizado \\
\cline { 2 - 3 } & Inventário - Acuracidade de estoque & Não utilizado \\
\cline { 2 - 3 } & Distribuição e controle da carga de trabalho & Não utilizado \\
\cline { 2 - 3 } & Monitoramento do desempenho do colaborador & Não utilizado \\
\cline { 2 - 3 } & Monitoramento e controle de produtividade por atividade & Não utilizado \\
\cline { 2 - 3 } & Variação do nível de serviço prestado & Otimizado \\
\cline { 2 - 3 } & Variação do nível de estoque & Não \\
\hline
\end{tabular}

Quadro 6 - Resumo da análise da Distribuidora X.

Dessa forma, identifica-se que boa parte dos benefícios da utilização do WMS foram atingidos, entretanto há ainda algumas funcionalidades a serem adotadas na operação. Quanto aos projetos futuros de melhoria, foram destacadas nas entrevistas a ampliação do armazém, em virtude da crescente demanda do mercado; a instalação de esteiras com leitor de código de barras a fim de agilizar o recebimento de mercadorias e uma modificação no processo de separação de pedidos, passando a ser realizado por nota fiscal com o intuito de melhor distribuir a carga no veículo, agilizando o processo de entrega.

\subsubsection{Atacado $Y$}

O Atacado $Y$ faz parte de uma rede de lojas de atacado em atuação no mercado há 50 anos, atualmente presente em 21 estados brasileiros, atendendo ao cliente com a ajuda de mais de 22.000 colaboradores.

Dentre todas as unidades, foi definido por conveniência o estudo e análise da filial Ribeirão Preto, que iniciou a operação em janeiro de 2010 e atualmente chega ao faturamento de 168 milhões de reais ao ano, traduzindo-se assim como uma 
empresa de grande porte. Uma questão interessante é que, apesar do tamanho da rede, a unidade estudada é a pioneira na implantação do WMS em sua operação, tendo este sistema de gestão sido aplicado desde a sua fundação. Tal fato é decorrente principalmente da dificuldade de outras filiais no controle de estoque, chegando a identificar no inventário físico diferenças da ordem de até 400 mil reais.

Esclarecendo a forma de trabalho, no mesmo local a empresa trabalha com duas subdivisões (autosserviço e atacado), com estoques, funcionários e gerências distintas. O autosserviço atende ao varejo, ou seja, pessoas físicas que vão até a unidade realizar as suas compras, oferecendo aproximadamente 11.000 produtos. Já o atacado atende apenas empresas, trabalhando com cerca de 2.500 SKUs, subdivididos em 4 classificações:

- Alimentos: $45 \%$ do estoque;

- Bebidas: $8 \%$ do estoque;

- Limpeza: 44\% do estoque;

- Confinados: $3 \%$ do estoque;

*A categoria "limpeza" abrange todos os produtos que não são alimentos ou bebidas, incluindo, portanto, a parte de perfumaria e shampoos, por exemplo.

Já os itens confinados são produtos armazenados em uma área segregada, com acesso restrito a poucos funcionários por se tratar de produtos com maior valor agregado ou ainda por ter certa propensão a furtos, como é o caso das lâminas de barbear e do whisky ou bebidas importadas.

Apesar de ambas operações ocorrerem na mesma estrutura física, apenas a área que atende ao atacado tem o WMS implantado, sendo por esse motivo o foco em análise. A operação faz uso da armazenagem vertical por meio da estrutura porta-palets, disponibilizando 4.956 posições para estocagem e a movimentação interna atualmente é realizada por 50 colaboradores e quatro empilhadeiras.

Dando suporte a esta estrutura, são utilizados dois softwares: o primeiro é o ERP da empresa (denominado SAVE), desenvolvido internamente, e o segundo é o Sistema de Gestão do Armazém (WMS), desenvolvido pela empresa Sythex. É importante frisar que ambos os sistemas interagem via interface, sendo que qualquer alteração realizada no SAVE é automaticamente refletida para o WMS, eliminando assim a possibilidade de divergência de informações.

Conforme relatado pelo analista de estoque entrevistado, o início da operação foi uma fase de intenso aprendizado por parte dos funcionários da filial Ribeirão 
Preto, tendo em vista que alguns tinham um conhecimento superficial sobre o WMS e a maioria desconhecia a ferramenta. Dessa forma, para a implantação e início das operações foi enviado de São Paulo um profissional que detinha o conhecimento teórico do sistema de gestão para a realização do treinamento dos colaboradores.

No decorrer deste processo de implantação a maior dificuldade encontrada não foi a questão de adaptação à forma de trabalho proposta pelo sistema, pois a operação desde o início foi realizada de forma alinhada ao processo imposto pelo WMS, mas sim a disciplina na execução destas atividades.

A rotina de trabalho do WMS tem como premissa a não realização de movimentações indevidas, não autorizadas pelo sistema. Fazer com que todos os colaboradores realizassem estritamente as ordens provenientes do sistema foi 0 maior desafio a ser superado.

Outra dificuldade foi o atendimento da matriz à filial Ribeirão Preto. Como a rede trabalha com foco em negócios de oportunidade, toda aquisição e distribuição de produtos é realizada com o intuito de minimizar o custo total de compra e transporte. Em alguns casos, as aquisições são entregues pelos fornecedores à matriz e esta faz a distribuição e, em outras situações, os fornecedores entregam diretamente nas filiais.

Essa duplicidade na forma de trabalho frequentemente acarreta uma inadequada programação de entregas nas filiais, gerando a entrega simultânea de uma grande quantidade de produtos e sobrecarregando o armazém, o que dificulta a realização e controle das atividades operacionais de recebimento, armazenagem, separação e expedição.

Feitas tais considerações, é importante que seja explicado como o sistema atua e que tipo de informações e benefícios pode gerar. Inicialmente, o cadastramento de todos os produtos para ambos os sistemas é realizado na matriz da rede, localizada em São Paulo capital, e repassado às suas unidades. Cabe a cada unidade a inserção das informações que caracterizam as suas condições operacionais no software WIS (WMS), como, por exemplo, o espaço disponível para armazenagem, prioridade das atividades, alas do armazém para as quais são destinados os produtos (restrições como temperatura e tipo de produto).

Um fator importante que contribui para a segurança das informações e para que sejam evitados erros operacionais é a existência de proteção contra contingências, como, por exemplo, a queda de energia. O software bloqueia os 
coletores de código de barras que estão sendo utilizados na operação caso haja uma queda de energia, desta forma, após a resolução do problema, reinicia-se o trabalho a partir do ponto de parada.

Cada colaborador que trabalha no recebimento, armazenagem, movimentação e separação de pedido tem o seu próprio coletor de código de barras, o que possibilita o monitoramento da produtividade dos funcionários através da comparação entre volume de trabalho previsto e o que foi realizado.

O acesso às funcionalidades do sistema é diferente para cada cargo existente, dessa forma o colaborador tem acesso restrito às aplicações diretamente relacionadas à sua função.

Além de monitorar a eficiência operacional de cada colaborador individualmente, o WMS disponibiliza ao gestor uma variedade considerável de relatórios que destacam informações referentes à operação e sua produtividade, o que possibilita a tomada de medidas corretivas mais assertivas caso necessário.

Um relatório checado frequentemente é o de produtividade, que fornece informações importantes como a porcentagem de ocupação do estoque e as movimentações realizadas. Assim como mencionado por alguns autores citados no referencial teórico, (BALLOU (2006); BANZATO (2010); GU, GOETSCHALCKX e MCGINNIS (2007)) recomendam que haja um monitoramento do nível de estoque no armazém, de forma que se mantenha aproximadamente $15 \%$ do espaço livre para eventuais sazonalidades no fornecimento e na demanda. A Figura 13 informa a posição do estoque.

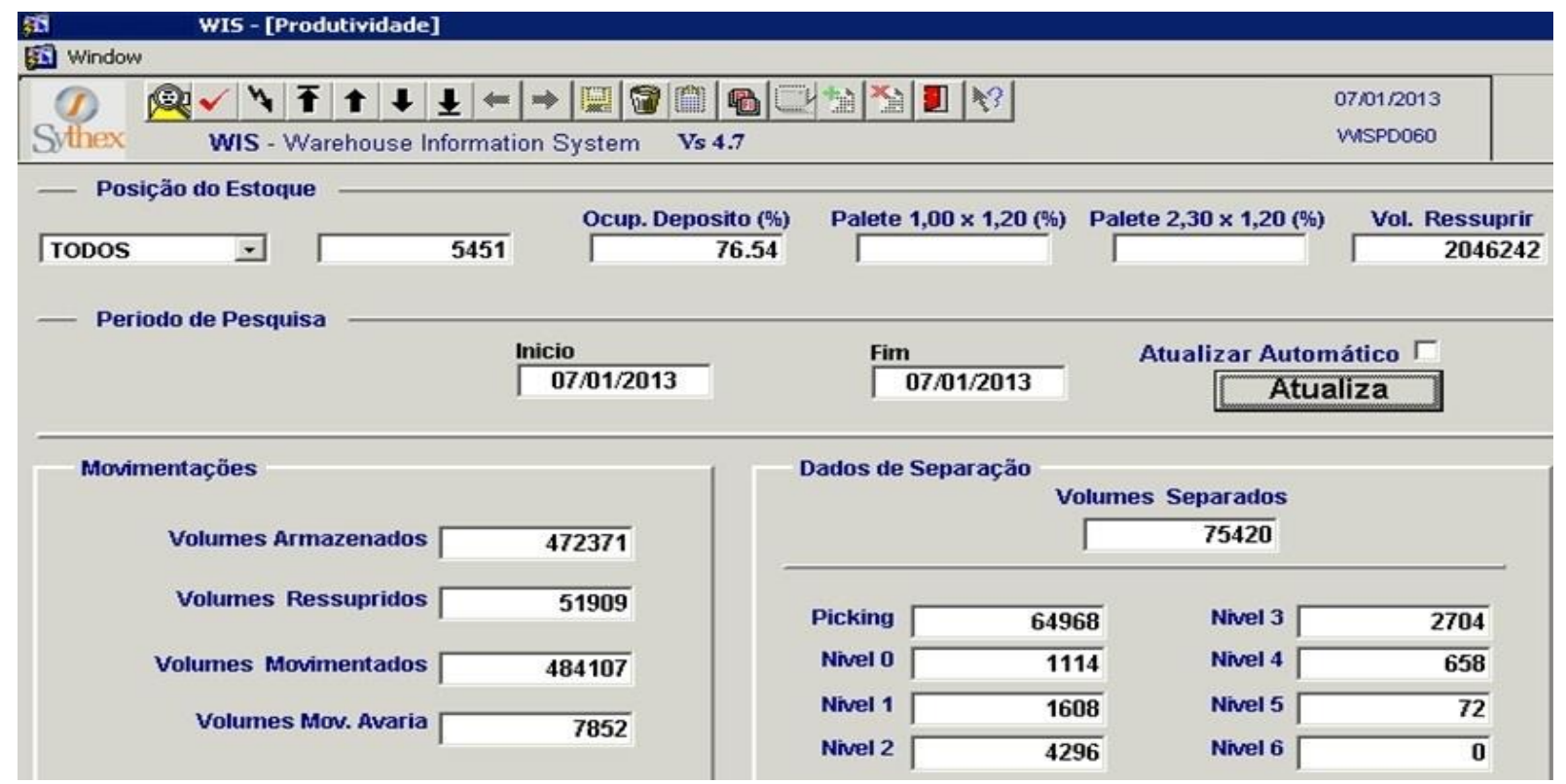

Figura 13 - Tela do relatório de produtividade do Atacado Y. 
Como é possível identificar na imagem acima, o relatório refere-se ao dia sete de janeiro de 2013 , no qual $76,54 \%$ das posições para armazenamento estavam ocupadas. No campo "Dados de Separação", o sistema indica quantos volumes foram separados no total e a quantidade por nível da estrutura de armazenagem, sendo a área de picking e nível zero os produtos alocados ao nível do chão, de fácil manejo, os demais níveis indicam o primeiro andar da estrutura vertical e assim subsequentemente.

Outro relatório de produtividade utilizado é o de distribuição de horas utilizadas, ilustrado pela Figura 14.

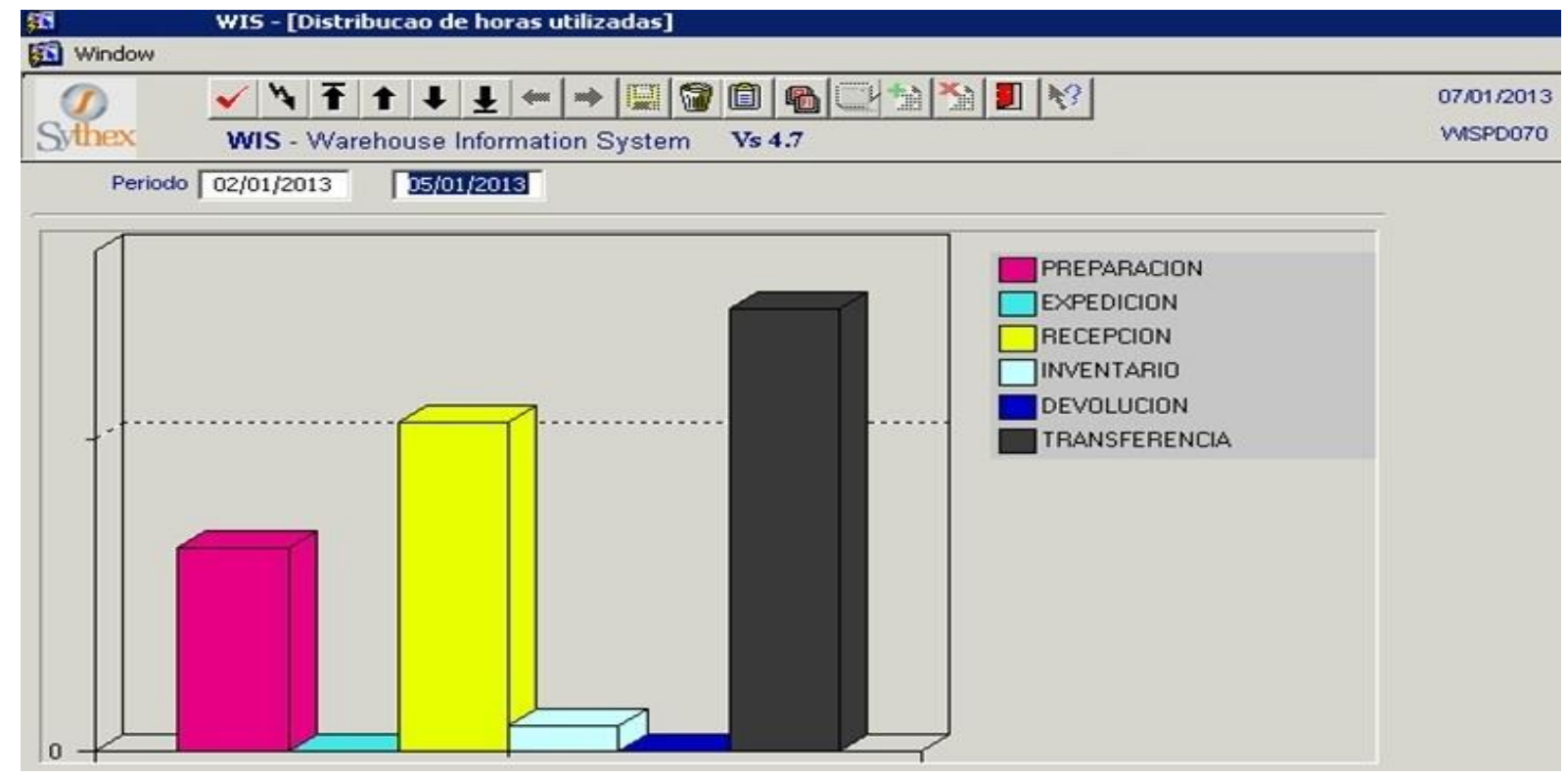

Figura 14 - Tela do relatório da distribuição de horas utilizadas do Atacado Y.

Conforme mostra o relatório acima, tem-se a estratificação da quantidade de horas trabalhadas por atividade, considerando-se a expedição, recebimento, realização de inventário, tratamento de devoluções e transferências. Neste contexto, identificou-se que o principal benefício obtido pelo Atacado $Y$ após a implantação do WMS foi o aumento do controle operacional. Tal capacidade de organização e monitoramento das atividades realizadas fez com que o problema inicial de baixa acuracidade de estoque fosse minimizado. Atualmente, conforme mostra a Figura 15 , este índice chega aos $96,4 \%$. 


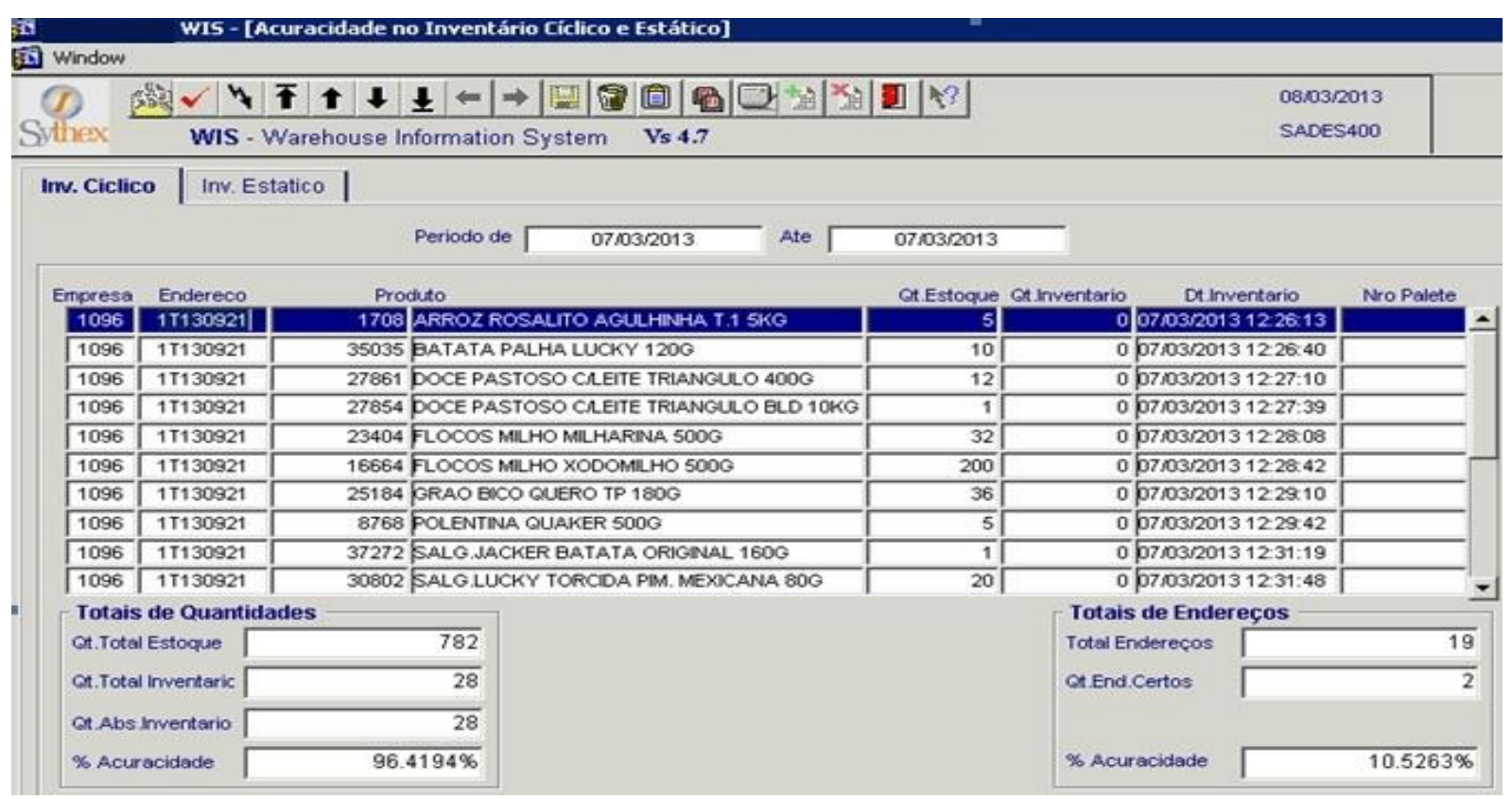

Figura 15 - Acuracidade de estoque do Atacado Y pós-implantação do WMS.

Finalizando o estudo de caso do Atacado $\mathrm{Y}$, o Quadro 7 ilustra uma análise das variáveis definidas para o estudo da implementação do WMS.

\begin{tabular}{|c|c|c|}
\hline Indicador & Variável & Atacado Y \\
\hline \multirow{4}{*}{$\begin{array}{c}\text { Gestão de } \\
\text { Pessoas }\end{array}$} & Conhecimento do conceito WMS antes da implantação & Não \\
\hline & Preparação e treinamento pré-implantação do WMS & Sim \\
\hline & Mapeamento e alinhamento dos processos organizacionais & Sim \\
\hline & Apoio da alta gerência & Sim \\
\hline \multirow{2}{*}{$\begin{array}{c}\text { Tecnologia da } \\
\text { Informação }\end{array}$} & Adequação às necessidades da operação & Sim \\
\hline & Integração com a tecnologia já adotada pela empresa & Sim \\
\hline \multirow{3}{*}{$\begin{array}{l}\text { Velocidade } \\
\text { operacional }\end{array}$} & Aumento da velocidade de recebimento & Sim \\
\hline & Aumento da velocidade de separação de pedidos & Sim \\
\hline & Aumento na velocidade de identificação de falhas & Sim \\
\hline \multirow{17}{*}{$\begin{array}{l}\text { Controle da } \\
\text { operação }\end{array}$} & Programação e sequenciamento do recebimento & Não utilizado \\
\hline & Controle de portaria e pátio & Não utilizado \\
\hline & Erros de conferência no recebimento & Minimizados \\
\hline & Melhor utilização do espaço disponível & Sim \\
\hline & Melhor visualização do estoque & Sim \\
\hline & Controle de lotes (rastreabilidade, FIFO) & Utilizado \\
\hline & Gerenciamento de devoluções & Utilizado \\
\hline & Programação e sequenciamento da separação de pedidos & Utilizado \\
\hline & Erros na separação do pedido & Minimizados \\
\hline & Erros de conferência no carregamento & Minimizados \\
\hline & Priorização de atividades & Não utilizado \\
\hline & Inventário - Acuracidade de estoque & Utilizado \\
\hline & Distribuição e controle da carga de trabalho & Não utilizado \\
\hline & Monitoramento do desempenho do colaborador & Utilizado \\
\hline & Monitoramento e controle de produtividade por atividade & Utilizado \\
\hline & Variação do nível de serviço prestado & Otimizado \\
\hline & Variação do nível de estoque & Não \\
\hline
\end{tabular}

Quadro 7 - Resumo da análise do Atacado Y. 


\subsubsection{Companhia de Bebidas Ipiranga}

Fundada em 1948, a Companhia de Bebidas Ipiranga é uma das maiores franquias do grupo Coca-Cola no Brasil. Sediada em Ribeirão Preto, a indústria atualmente atende a mais de 25.000 pontos de vendas, distribuídos em 131 cidades, oferecendo 340 SKUs.

Para realizar o atendimento desta demanda, a empresa dispõe de mais cinco unidades, localizadas em Araraquara, Franca, São João da Boa Vista, Mococa e São Sebastião do Paraíso. Na logística interna da matriz, objeto de estudo desta dissertação, atuam aproximadamente 200 funcionários, sendo utilizadas 35 empilhadeiras e 30 coletores de código de barras.

Neste contexto, foram identificadas as principais razões para a adoção do sistema: o alto volume de erros operacionais e a consequente baixa acuracidade de estoque. Por este motivo, em 2008 iniciou-se a implantação do sistema de gestão WMS, projeto fortemente apoiado pela diretoria e gerência da empresa e que teve a duração de seis meses (o mesmo para a percepção de benefícios significativos).

Segundo o analista de estoque responsável pela gestão da armazenagem da unidade de Ribeirão Preto, na fase de pré-implantação, a maioria dos colaboradores não conhecia o conceito do Warehouse Management System, desta forma, foram realizados treinamentos com os funcionários envolvidos na operação. Mesmo com essa orientação prévia, a adaptação dos colaboradores à forma de trabalho proposta pelo WMS foi a maior dificuldade enfrentada.

O treinamento durou alguns dias, entretanto não houve tempo para que fosse executada uma simulação com os funcionários envolvidos na operação, o que contribuiu para o surgimento de dúvidas no momento em que o WMS passou a ser aplicado na rotina operacional.

A fim de minimizar tais transtornos, a empresa destaca a importância de que haja uma boa equipe multiplicadora, composta por ao menos um funcionário ocupante de cada cargo relevante para a operação logística (conferente, operador de empilhadeira, estoquista e assistente de estoque).

O criterioso treinamento destas pessoas justifica-se segundo a ótica de que, mesmo após todos os colaboradores receberem instruções, no momento da mudança para a nova forma de trabalho ainda haverá dúvidas por parte de alguns 
funcionários. É justamente no auxílio da resolução de tais dúvidas que a equipe multiplicadora pode atuar.

Realizados o treinamento e o "go live" (virada para a nova forma de trabalhar proposta pelo WMS), alguns procedimentos foram alterados, como o processo de devolução e a separação de pedidos. Nestas atividades, o que anteriormente era feito através de fichas em papel passou a ser realizado pelo coletor de código de barras, uma mudança fundamental para a minimização de erros operacionais.

Houve alteração também na forma de execução do inventário - semanalmente são contados os produtos alocados na área de picking, mensalmente é realizada uma contagem geral do estoque e trimestralmente a realização do inventário é acompanhada pela auditoria.

Segundo a empresa, antes da implantação do sistema, quando o inventário era realizado identificavam-se diferenças (falta ou sobra) de palets completos em diversos produtos. Atualmente, a divergência se resume a algumas caixas em poucos itens. A Figura 16 mostra a acuracidade de estoque em 2012.

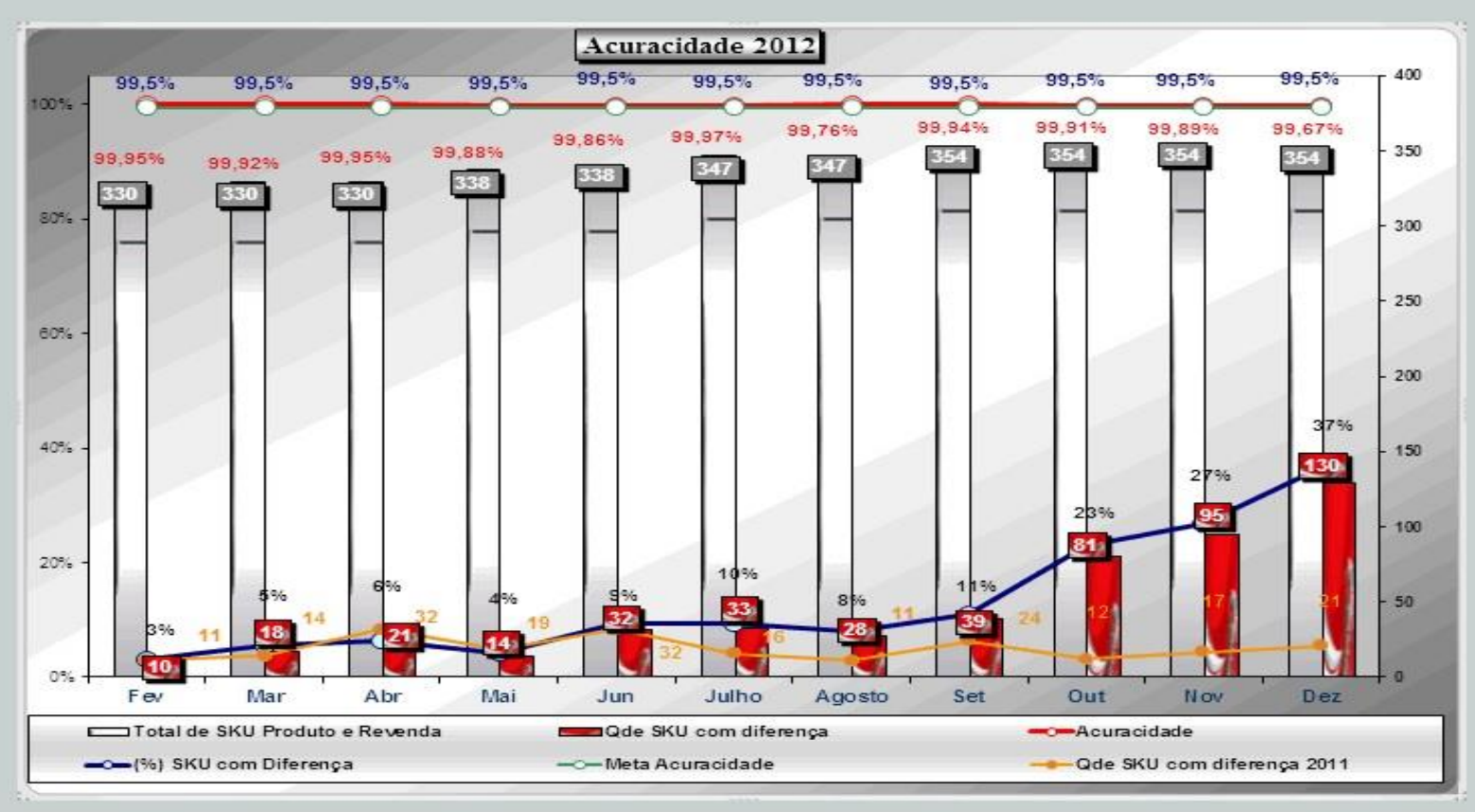

Figura 16 - Resumo acuracidade de estoque 2012.

Os números inseridos nos campos cinzas indicam a quantidade de SKUs fabricados pela empresa no referido mês, enquanto os números inseridos nos quadrados vermelhos indicam o número de SKUs nos quais foi identificada alguma diferença de estoque. Conforme ilustrado pela Figura 16, a meta da empresa é 
99,5\% de acuracidade, sendo que em todos os meses de 2012 ela foi superada, chegando ao pico de 99,97\%.

Todas as informações descritas na figura acima podem ser visualizadas pelos colaboradores responsáveis pela gestão da armazenagem através do relatório de divergências de estoque:

\begin{tabular}{|c|c|c|c|c|c|c|c|c|c|c|c|}
\hline Vaterial & Texto breve material & Ip. & PosDepóosit & Estg. dispon. & ONB & Data venc. & UD & $\mathbb{I}^{\circ} \mathrm{EN}$ & Data E!! & MaxUGE & Hora \\
\hline 2 & COCA-COLA KS 290NL 24XI & 999 & ACERTO & 8,319 & $|\mathrm{CXE}|$ & $09,07,2013$ & & 16547610 & $\mid 10,01,2013$ & 0 & $09: 23: 01$ \\
\hline 4 & COCA-COLA IS 1,002 1281 & 999 & ACERTO & 21,341 & $|\operatorname{CXE}|$ & $17.07,2013$ & & 166511162 & $\mid 19,01,2013$ & 0 & $09: 42: 37$ \\
\hline 5 & FAITA LARAIJA KS 290VL 24X1 & 999 & ACERTO & 6,580 & CXE & $22,06,2013$ & & 16369569 & $24,12,2012$ & 0 & 14:35:01 \\
\hline 6 & FAITA ONA KS 290NL 24X1 & 999 & ACERTO & 20,707 & CXE & & & 16359738 & $23,12,2012$ & 0 & $14: 34: 22$ \\
\hline 7 & HEINEKEN LATA 35OML $12 \times 1$ BD & 999 & ACERTO & 23,494 & CXE & & & 4945084044 & $23,01.2013$ & 0 & 14:16:31 \\
\hline 9 & FAITA LARANA IS 1,00L $12 \times 1$ & 999 & ACERTO & 9,085 & $\operatorname{CXF} \mid$ & $06,07,2013$ & & 16499359 & $07,01.2013$ & 0 & $12: 43: 10$ \\
\hline 10 & 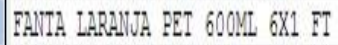 & 999 & ACERTO & 5,162 & $|\mathrm{CXE}|$ & $24,12,2013$ & & 16441628 & $29,12,2012$ & 0 & $08: 24: 34$ \\
\hline 14 & SPRIIE KS 300VE 24XI & 999 & ACERTO & 2,830 & CXI & $09,07,2013$ & & 16566429 & 11.01 .2013 & 0 & 09:23:01 \\
\hline 20. & FAITA JWA PET 600VL 6X1 BT & 999 & ACERTO & 8,499 & CXE & $24,12,2013$ & & 4944841835 & $16,01.2013$ & 0 & $15: 29: 02$ \\
\hline 22 & SPRITE PET 6OOYL 6X1 RT & 999 & ACERTO & $0,338-$ & $|\operatorname{CXF}|$ & $\mid 03.03 .2013$ & & 16454792 & $02,01,2013$ & 0 & 08:49:07 \\
\hline
\end{tabular}

Figura 17 - Relatório de divergências de estoque.

Pode-se afirmar, com isso, que a causa raiz para esta robusta minimização do principal problema que a empresa tinha na sua gestão da armazenagem foi o maior controle operacional propiciado pelo WMS. Através dos relatórios fornecidos pelo sistema foi possível minimizar os erros de separação e conferência (tanto no recebimento como na expedição), aprimorar a rastreabilidade dos produtos, bem como o seu controle de estoque e devoluções.

Apesar dos resultados positivos, nem todos os recursos do sistema são utilizados pela empresa. Funcionalidades como o agendamento do recebimento, gestão de portaria e sequenciamento da separação dos pedidos são executadas por outros softwares como, por exemplo, o Moniloc (agendamento dos horários de recebimento e expedição) e o Real Distribution (gerenciamento dos pedidos). Além disso, existem algumas funcionalidades que não são aplicáveis à rotina operacional da empresa, como, por exemplo, o Cross Docking.

Além da maior acuracidade de estoque já mencionada, a utilização das funcionalidades do sistema gerou à empresa benefícios operacionais qualitativos, no sentido de que a velocidade da execução das atividades foi minimamente alterada, enquanto os erros operacionais foram fortemente reduzidos, acarretando em maior eficiência. 
Estes benefícios mencionados não reduziram o estoque da empresa, entretanto, através do relatório geral do estoque a equipe responsável pela sua gestão pode diariamente identificar quais são os itens em excesso e repassar esta informação à área de produção para que, através da programação de fabricação, seja possível adequar os níveis de estoque por produto.

Com estes resultados positivos, após a implantação na unidade de Ribeirão Preto, o WMS passou a ser utilizado gradualmente nas demais filiais. Em virtude do know how adquirido, as dificuldades enfrentadas na matriz foram mais facilmente superadas nas outras unidades da empresa e os benefícios da ferramenta puderam ser percebidos mais rapidamente, o que reduziu o tempo de retorno sobre o investimento realizado.

Feitas tais considerações sobre o caso da Cia de Bebidas Ipiranga, o Quadro 8 sintetiza a análise da empresa conforme os indicadores e variáveis definidos para a análise de conteúdo.

\begin{tabular}{|c|l|c|}
\hline \multirow{2}{*}{ Indicador } & \multicolumn{1}{|c|}{ Variável } & $\begin{array}{c}\text { Cia de Bebidas } \\
\text { Ipiranga }\end{array}$ \\
\hline \multirow{4}{*}{$\begin{array}{c}\text { Gestão de } \\
\text { Pessoas }\end{array}$} & Conhecimento do conceito WMS antes da implantação & Não \\
\cline { 2 - 3 } & Preparação e treinamento pré-implantação do WMS & Sim \\
\cline { 2 - 3 } $\begin{array}{c}\text { Tecnologia da } \\
\text { Informação }\end{array}$ & Mapeamento e alinhamento dos processos organizacionais & Sim \\
\cline { 2 - 3 } $\begin{array}{c}\text { Velocidade } \\
\text { operacional }\end{array}$ & Apoio da alta gerência & Sim \\
\cline { 2 - 3 } & Integração às necessidades da operação & Sim \\
\hline \multirow{5}{*}{$\begin{array}{l}\text { Conecnologia já adotada pela empresa } \\
\text { operação }\end{array}$} & Aumento da velocidade de recebimento & Não \\
\cline { 2 - 3 } & Aumento na velocidade de separação de pedidos & Não \\
\hline & Programação e sequenciamento do recebimento & Sim \\
\cline { 2 - 3 } & Controle de portaria e pátio & Não utilizado \\
\cline { 2 - 3 } & Erros de conferência no recebimento & Minimizizados \\
\cline { 2 - 3 } & Melhor utilização do espaço disponível & Sim \\
\cline { 2 - 3 } & Melhor visualização do estoque & Sim \\
\cline { 2 - 3 } & Controle de lotes (rastreabilidade, FEFO) & Utilizado \\
\cline { 2 - 3 } & Gerenciamento de devoluçães & Utilizado \\
\cline { 2 - 3 } & Programação e sequenciamento da separação de pedidos & Utilizado \\
\cline { 2 - 3 } & Erros na separação do pedido & Minimizados \\
\cline { 2 - 3 } & Erros de conferência no carregamento & Minimizados \\
\cline { 2 - 3 } & Priorização de atividades & Não utilizado \\
\cline { 2 - 3 } & Inventário - Acuracidade de estoque & Utilizado \\
\cline { 2 - 3 } & Distribuição e controle da carga de trabalho & Não utilizado \\
\cline { 2 - 3 } & Monitoramento do desempenho do colaborador & Não utilizado \\
\cline { 2 - 3 } & Monitoramento e controle de produtividade por atividade & Não utilizado \\
\cline { 2 - 3 } & Variação do nível de serviço prestado & Otimizado \\
\cline { 2 - 3 } & Variação do nível de estoque & Não \\
\hline
\end{tabular}

Quadro 8 - Resumo da análise da Cia de Bebidas Ipiranga. 


\section{RESULTADOS E DISCUSSÃO}

Nesta seção, os dados obtidos através das entrevistas nas empresas desenvolvedoras de software e organizações usuárias do WMS foram compilados e analisados, gerando uma comparação entre os casos estudados feita inicialmente dentro das duas categorias dos objetos de estudo: primeiramente compara-se as funcionalidades do WMS identificadas na literatura consultada com as informações obtidas nos desenvolvedores; em seguida, a análise aborda as dificuldades enfrentadas pelas empresas usuárias do sistema no decorrer de sua implantação, bem como os benefícios obtidos por elas.

\subsection{ANÁLISE DOS DESENVOLVEDORES DO SOFTWARE WMS}

Esta análise realiza a comparação dos dados obtidos nas entrevistas realizadas com a PC Sistemas e a Sythex, identificando os principais pontos destacados quanto às dificuldades existentes na implantação do WMS, bem como as funcionalidades e benefícios atualmente oferecidos ao mercado.

Com base nos discursos analisados, constatou-se que, para esta amostra de empresas, o perfil do cliente que busca a implantação do WMS envolve empresas que detêm algum conhecimento prévio da ferramenta, entretanto sem profundidade. Geralmente as empresas conhecem superficialmente o conceito WMS no tocante aos entraves existentes para a sua implementação e os benefícios que o sistema oferece, situação em consonância com o pensamento de Banzato et al. (2010), já mencionado na introdução.

Neste contexto, observa-se que há indícios de que o fato de a maior parte das empresas não utilizar todo o potencial oferecido pelo sistema está vinculado à questão acima destacada, bem como ao comodismo, no qual o cliente implanta o sistema de gestão, elimina algumas dificuldades que havia identificado em sua rotina de trabalho, entretanto não explora as demais possibilidades de otimização operacional oferecidas pelo software, aqui denominadas como funcionalidades do sistema.

Primeiro foi realizada uma compilação das funcionalidades oferecidas pelo WMS baseando-se na literatura consultada (Quadro 2). Em um segundo momento, elaborou-se o Quadro 9, que contempla as funcionalidades do WMS oferecidas ao 
mercado pelos desenvolvedores de software consultados. Comparando-se os dois quadros percebe-se que praticamente todas as funcionalidades mencionadas na literatura foram identificas nas empresas estudadas.

\begin{tabular}{|c|c|}
\hline Processo & Funcionalidade \\
\hline \multirow{7}{*}{ Recebimento } & Agendamento do recebimento \\
\hline & Captação de notas fiscais dos fornecedores via EDI \\
\hline & Cálculo dos recursos necessários para o recebimento \\
\hline & Gestão de portaria \\
\hline & Convocação ativa para recebimento \\
\hline & Priorização de desembarque \\
\hline & Controle de divergências no recebimento \\
\hline \multirow{11}{*}{ Armazenagem } & Análise da fragmentação dos espaços \\
\hline & Sugestão de reorganização de estoque \\
\hline & Gestão de lotes \\
\hline & Gestão de Shelf-Life \\
\hline & Classificação do status do item \\
\hline & Convocação ativa para armazenagem \\
\hline & Setorização dos locais de armazenagem \\
\hline & Cadastramento das restrições físicas de armazenagem \\
\hline & Endereçamento automático pela Curva ABC \\
\hline & Reabastecimento automático do picking \\
\hline & Realização de inventários cíclicos e estáticos \\
\hline \multirow{7}{*}{$\begin{array}{l}\text { Separação de } \\
\text { Pedidos }\end{array}$} & Convocação ativa para separação e conferência \\
\hline & Ondas de separação parametrizada por regras pré-definidas \\
\hline & Cálculo dos recursos necessários para a separação de pedidos \\
\hline & Picking, priorizando clientes e/ou rotas \\
\hline & Definição de percurso lógico para separação \\
\hline & Controle de separação em tempo real \\
\hline & Conferência dupla de expedição \\
\hline \multirow{16}{*}{$\begin{array}{l}\text { Relatórios } \\
\text { Gerenciais }\end{array}$} & Ocupação do armazém \\
\hline & Visualização gráfica do armazém em 3D online \\
\hline & Detalhamento do inventário \\
\hline & Registro de entradas e saídas por produto, endereço e operador \\
\hline & Resumo de todas as operações (geral, recebimento, armazenagem e expedição) \\
\hline & Análise do desempenho da operação de recebimento \\
\hline & Análise do desempenho da operação de separação de pedidos \\
\hline & Análise do desempenho no atendimento dos pedidos \\
\hline & Análise por produto, volume, transação, período e funcionário \\
\hline & $\begin{array}{l}\text { Parametrização dos tempos médios por tarefa, considerando a distância a ser } \\
\text { percorrida, tipo de equipamento utilizado e família de produto movimentada }\end{array}$ \\
\hline & $\begin{array}{l}\text { Registro do tempo gasto em tarefas, tempo ocioso aguardando convocação e } \\
\text { tempo decorrido para aceitar convocação }\end{array}$ \\
\hline & Análise de produtividade por operador, equipe, tarefa ou turno \\
\hline & Planejamento de carga de trabalho \\
\hline & Rastreabilidade das tarefas \\
\hline & $\begin{array}{l}\text { Definição de atividades prioritárias por operador, tipo de equipamento utilizado, } \\
\text { área de atuação e família de produto }\end{array}$ \\
\hline & Distribuição automática de tarefas pendentes \\
\hline
\end{tabular}

Quadro 9 - Resumo das funcionalidades do WMS (Sythex e PC Sistemas). 
Foram também observados os pontos positivos e negativos da implantação do WMS, ou seja, os benefícios oferecidos pela ferramenta e as dificuldades existentes para a implantação desta, bem como as tendências para o aprimoramento do software. Essa análise é mostrada a seguir pelo Quadro 10.

\begin{tabular}{|c|c|c|}
\hline Variáveis & PC Sistemas & Sythex \\
\hline \multirow{5}{*}{$\begin{array}{l}\text { Dificuldades na } \\
\text { Implementação }\end{array}$} & $\begin{array}{l}\text { Investimento inicial (empresas de } \\
\text { pequeno porte) }\end{array}$ & $\begin{array}{l}\text { Investimento inicial (empresas de } \\
\text { pequeno porte) }\end{array}$ \\
\hline & Preparação Cultural & Mudança Cultural \\
\hline & Apoio da diretoria & Apoio da diretoria \\
\hline & $\begin{array}{l}\text { Mapeamento dos processos } \\
\text { organizacionais }\end{array}$ & $\begin{array}{l}\text { Definição dos processos de } \\
\text { negócio }\end{array}$ \\
\hline & Cadastramento de informações & Cadastramento de informações \\
\hline \multirow{9}{*}{ Benefícios } & $\begin{array}{l}\text { Recebimento mais rápido e } \\
\text { assertivo }\end{array}$ & Recebimento eficiente \\
\hline & $\begin{array}{l}\text { Maior controle e agilidade na } \\
\text { armazenagem }\end{array}$ & $\begin{array}{l}\text { Maior controle da operação de } \\
\text { armazenagem }\end{array}$ \\
\hline & $\begin{array}{l}\text { Separação de pedidos mais rápida } \\
\text { e assertiva }\end{array}$ & $\begin{array}{l}\text { Maior velocidade e minimização } \\
\text { dos erros na separação de pedidos }\end{array}$ \\
\hline & $\begin{array}{l}\text { Inventários mais precisos } \\
\text { (acuracidade de estoque) }\end{array}$ & Melhor acuracidade de estoque \\
\hline & Minimização da ociosidade & Redução da ociosidade operacional \\
\hline & $\begin{array}{l}\text { Redução da ocorrência de erros } \\
\text { operacionais }\end{array}$ & Minimização de erros operacionais \\
\hline & $\begin{array}{l}\text { Melhoria do nível de serviço } \\
\text { prestado }\end{array}$ & Aprimoramento do nível de serviço \\
\hline & $\begin{array}{l}\text { Tomada de decisão baseada em } \\
\text { fatos }\end{array}$ & Relatórios de suporte gerencial \\
\hline & $\begin{array}{l}\text { Acompanhamento da operação } \\
\text { online e em tempo real }\end{array}$ & $\begin{array}{l}\text { Acompanhamento da operação } \\
\text { online e em tempo real }\end{array}$ \\
\hline \multirow{3}{*}{ Tendências para o WMS } & $\begin{array}{l}\text { Desenvolvimento de novos } \\
\text { indicadores de desempenho }\end{array}$ & $\begin{array}{l}\text { Desenvolvimento de relatórios } \\
\text { personalizados }\end{array}$ \\
\hline & $\begin{array}{l}\text { Mobilidade (vinculação a } \\
\text { smartphones e tablets) }\end{array}$ & Adaptação à tecnologia RFID \\
\hline & Adaptação à tecnologia RFID & \\
\hline
\end{tabular}

Quadro 10- Resumo da análise dos desenvolvedores do software WMS.

Observa-se que ambas as empresas proveram informações consideravelmente semelhantes nas três variáveis analisadas. É importante salientar que, segundo as entrevistas, identificou-se como fator crítico de sucesso para a implantação do WMS a capacidade da empresa de ter os seus processos organizados e mapeados, além de um cadastro de produtos sem erros de digitação ou duplicidade de informação, fator não mencionado na literatura consultada.

Segundo os entrevistados, a adoção do WMS implica em fortes mudanças na forma de realização dos processos relacionados à armazenagem, sendo assim, quando estes não se encontram mapeados e organizados começam a ocorrer diversos problemas advindos de diferentes áreas da empresa que bloqueiam ou 
atrasam a realização da operação logística. Estes fatores foram considerados pelos dois desenvolvedores de software as principais causas para a suspensão ou prolongamento do projeto de implantação do sistema, caracterizando-se como questões que exigem uma maior atenção por parte dos responsáveis pela implantação do sistema de gestão da armazenagem.

Quando superadas tais dificuldades, geralmente após um período de três meses a um ano, as empresas usuárias têm condições de obter os benefícios mencionados pela Sythex e PC Sistemas no quadro anterior.

Por fim, como tendências ao aprimoramento do sistema WMS destacam-se o desenvolvimento de relatórios personalizados e de melhor visualização, bem como a disponibilização da ferramenta por meio da mobilidade (smartphones e tablets) e a integração com tecnologia RFID, ainda pouco utilizada no país.

Finalizada a análise das informações provenientes das empresas desenvolvedoras do software WMS, a seção a seguir aborda a análise das empresas usuárias deste sistema.

\subsection{ANÁLISE DAS EMPRESAS USUÁRIAS DO WMS}

Esta seção faz a análise comparativa das operações executadas pela Distribuidora X, Atacado Y e a Cia de Bebidas Ipiranga, abordando os indicadores e variáveis propostos nos procedimentos metodológicos, identificando semelhanças e divergências, considerando-se operações distintas.

$\mathrm{Na}$ fase de implantação do WMS, os desenvolvedores de software salientaram como principais dificuldades a ser superadas a realização de um bom cadastro de produtos e a adaptação da cultura de trabalho dos colaboradores, pontos confirmados pelas empresas usuárias entrevistadas.

Nesta etapa, as três empresas trabalharam da mesma forma, em contextos semelhantes, no sentido de que o nível de conhecimento do sistema por parte dos funcionários era baixo e foram realizados treinamentos prévios, juntamente com o mapeamento dos processos inerentes à operação de armazenagem, bem como o apoio constante da diretoria e gerência ao projeto.

Para a implantação do sistema, os usuários buscaram no mercado a tecnologia da informação necessária e adaptaram-na aos sistemas já utilizados pela empresa. Vale ressaltar que nos casos da Distribuidora $\mathrm{X}$ e Atacado $\mathrm{Y}$, o WMS não 
era um módulo do ERP da empresa, mas sim um software em separado que se integra ao sistema da organização através de interface.

Outro ponto a ser considerado é que em nenhum dos casos estudados havia a integração das informações provenientes do WMS com empresas terceiras.

$O$ incremento da velocidade das atividades operacionais ocorreu apenas na Distribuidora X e no Atacado Y. Em ambos os casos, até a implantação do WMS, as operações de recebimento e separação de pedidos eram realizadas manualmente (guia em papel), percebeu-se um aumento significativo na produtividade destas operações. Já na Cia de Bebidas Ipiranga este cenário não se repetiu, pois mesmo antes da implantação deste projeto a empresa utilizava coletores de código de barras na sua operação.

Contudo, a característica comum identificada nestas operações e também o principal benefício destacado pelas empresas foi o drástico aumento na capacidade de monitoramento e controle da operação. Pode-se afirmar que os três objetos de estudo, através do WMS, foram capazes de aprimorar a ocupação do armazém, rastrear o fluxo de produtos (FIFO, FEFO e devoluções) e diminuir os erros operacionais, oferecendo um melhor nível de serviço ao cliente.

Evidentemente algumas das funcionalidades oferecidas pelo sistema não são atualmente utilizadas por estas empresas; a razão principal para tal fato, constatada nas entrevistas realizadas, mas não mencionada pela literatura consultada, é a indisponibilidade de pessoal suficiente para a realização adequada da atividade de controle e monitoramento operacional. Nos três usuários do sistema WMS, encontrou-se a característica em comum da necessidade de colaboradores em quantidade e qualidade suficiente para que seja possível para a empresa usufruir de todos os benefícios oferecidos pela ferramenta.

Segundo os próprios entrevistados, este é o principal motivo pelo qual a maior parte das empresas, apesar de ter adquirido o software, não utiliza o mesmo por completo. A seguir, o Quadro 11 faz o resumo desta análise dos usuários de WMS estudados, com base nos indicadores pré-definidos. 


\begin{tabular}{|c|c|c|c|c|}
\hline Indicador & Variável & $\begin{array}{l}\text { Distribuidora } \\
\mathrm{X}\end{array}$ & Atacado Y & $\begin{array}{l}\text { Cia de } \\
\text { Bebidas } \\
\text { Ipiranga }\end{array}$ \\
\hline \multirow{4}{*}{$\begin{array}{l}\text { Gestão de } \\
\text { Pessoas }\end{array}$} & $\begin{array}{l}\text { Conhecimento do conceito } \\
\text { WMS antes da implantação }\end{array}$ & Não & Não & Não \\
\hline & $\begin{array}{l}\text { Preparação e treinamento pré- } \\
\text { implantação do WMS }\end{array}$ & Sim & Sim & Sim \\
\hline & $\begin{array}{l}\text { Mapeamento e alinhamento dos } \\
\text { processos organizacionais }\end{array}$ & Sim & Sim & Sim \\
\hline & Apoio da alta gerência & Sim & Sim & Sim \\
\hline \multirow{2}{*}{$\begin{array}{l}\text { Tecnologia da } \\
\text { Informação }\end{array}$} & $\begin{array}{l}\text { Adequação às necessidades da } \\
\text { operação }\end{array}$ & $\operatorname{Sim}$ & $\operatorname{Sim}$ & Sim \\
\hline & $\begin{array}{l}\text { Integração com a tecnologia já } \\
\text { adotada pela empresa }\end{array}$ & Sim & Sim & Sim \\
\hline \multirow{3}{*}{$\begin{array}{l}\text { Velocidade } \\
\text { operacional }\end{array}$} & $\begin{array}{l}\text { Aumento da velocidade de } \\
\text { recebimento }\end{array}$ & Sim & Sim & Não \\
\hline & $\begin{array}{l}\text { Aumento da velocidade de } \\
\text { separação de pedidos }\end{array}$ & Sim & Sim & Não \\
\hline & $\begin{array}{l}\text { Aumento na velocidade de } \\
\text { identificação de falhas } \\
\text { operacionais }\end{array}$ & Sim & Sim & Sim \\
\hline \multirow{17}{*}{$\begin{array}{l}\text { Controle da } \\
\text { operação }\end{array}$} & $\begin{array}{l}\text { Programação e sequenciamento } \\
\text { do recebimento }\end{array}$ & Não utilizado & Não utilizado & Não utilizado \\
\hline & Controle de portaria e pátio & Não utilizado & Não utilizado & Não utilizado \\
\hline & $\begin{array}{l}\text { Erros de conferência no } \\
\text { recebimento }\end{array}$ & Minimizados & Minimizados & Minimizados \\
\hline & $\begin{array}{l}\text { Melhor utilização do espaço } \\
\text { disponível }\end{array}$ & Sim & Sim & Sim \\
\hline & Melhor visualização do estoque & Sim & Sim & Sim \\
\hline & Controle de lotes & Utilizado & Utilizado & Utilizado \\
\hline & Gerenciamento de devoluções & Utilizado & Utilizado & Utilizado \\
\hline & $\begin{array}{l}\text { Programação e sequenciamento } \\
\text { da separação de pedidos }\end{array}$ & Utilizado & Utilizado & Utilizado \\
\hline & Erros na separação do pedido & Minimizados & Minimizados & Minimizados \\
\hline & $\begin{array}{l}\text { Erros de conferência no } \\
\text { carregamento }\end{array}$ & Minimizados & Minimizados & Minimizados \\
\hline & Priorização de atividades & Não utilizados & Não utilizado & Não utilizado \\
\hline & $\begin{array}{l}\text { Inventário - Acuracidade de } \\
\text { estoque }\end{array}$ & Não utilizado & Utilizado & Utilizado \\
\hline & $\begin{array}{l}\text { Distribuição e controle da carga } \\
\text { de trabalho }\end{array}$ & Não utilizado & Não utilizado & Não utilizado \\
\hline & $\begin{array}{l}\text { Monitoramento do desempenho } \\
\text { do colaborador }\end{array}$ & Não utilizado & Utilizado & Não utilizado \\
\hline & $\begin{array}{l}\text { Monitoramento e controle de } \\
\text { produtividade por atividade }\end{array}$ & Não utilizado & Utilizado & Não utilizado \\
\hline & $\begin{array}{l}\text { Variação do nível de serviço } \\
\text { prestado }\end{array}$ & Otimizado & Otimizado & Otimizado \\
\hline & Variação do nível de estoque & Não & Não & Não \\
\hline
\end{tabular}

Quadro 11 - Resumo da análise das empresas usuárias do WMS. 


\section{CONSIDERAÇÕES FINAIS}

Conforme proposto inicialmente, esta dissertação teve como objetivo central realizar um estudo sobre o sistema WMS em um grupo de desenvolvedores e empresas usuárias. Para tanto, foi realizado o estudo multicasos, no qual foram entrevistadas duas empresas desenvolvedoras do software (PC Sistemas e Sythex) e três organizações usuárias do sistema de gerenciamento da armazenagem (Distribuidora X, Atacado Y e Cia de Bebidas Ipiranga).

Com base na análise de conteúdo das informações obtidas, foi possível a elaboração de algumas considerações quanto às dificuldades enfrentadas pelas empresas na implantação do WMS, as principais funcionalidades disponíveis ao mercado e utilizadas pela amostra estudada, bem como os benefícios oferecidos pelo sistema.

Primeiramente, quanto às barreiras para a implantação do WMS, houve dois pontos de vistas distintos: o dos desenvolvedores, destacando a importância da realização de um bom cadastro de produto e o mapeamento dos processos organizacionais por parte das empresas usuárias como fatores determinantes para a o sucesso do projeto de implementação do sistema, sendo confirmados pelas empresas usuárias do sistema; e a visão das empresas usuárias, que salienta a relevância do treinamento prévio dos colaboradores envolvidos na operação, além da criação de uma equipe multiplicadora do conhecimento ministrado a fim de orientar e solucionar algumas dúvidas operacionais que ocorram no início da execução da nova rotina de trabalho proposta pelo WMS.

As funcionalidades atualmente oferecidas ao mercado pelos desenvolvedores analisados podem ser observadas no Quadro 9. Ao verificar com as empresas usuárias quais dos itens mencionados neste quadro são utilizados nas suas atividades diárias, pode-se observar um padrão: funções como endereçamento automático, controle de devolução, rastreabilidade e controle dos lotes, realização do inventário e acompanhamento da operação do armazém são algumas das funcionalidades mais utilizadas.

Justificando o não aproveitamento de todos os recursos oferecidos pelo sistema, nesta amostra de empresas, tem-se basicamente duas razões. A primeira ocorre quando a funcionalidade não é aplicável à forma de trabalho da empresa, como é o caso do cross-docking não utilizado na operação da Cia de Bebidas 
Ipiranga; a segunda corresponde à falta de disponibilidade de pessoal capacitado para o manejo do WMS, necessitando a contratação de um número maior de pessoas qualificadas e disponibilizando mão-de-obra suficiente para que seja realizado o monitoramento e controle da operação através de todos os recursos (ou dos mais eficientes para determinada operação) que o sistema oferece.

Apesar de a amostragem ser pequena, com base nos discursos analisados, há indícios de que ambas as situações mencionadas anteriormente, segundo as cinco empresas estudadas, fazem parte do contexto de muitas organizações que fazem uso deste sistema de gestão da armazenagem. Segundo as empresas participantes da presente pesquisa, normalmente há a disponibilidade de colaboradores para a utilização das funcionalidades básicas do software, mas não para o uso completo da ferramenta, o que minimiza possíveis ganhos operacionais.

Outro ponto relevante é a dificuldade da mensuração quantitativa do retorno que a utilização do WMS proporciona. Nas empresas usuárias foi possível identificar indicadores como a melhoria na acuracidade de estoque, na distribuição da carga de trabalho por atividade operacional ou ainda a maior satisfação dos próprios funcionários em trabalhar de forma mais organizada. Todavia, como estas empresas enquadram-se na situação já descrita de falta de colaboradores para o completo uso do sistema, os benefícios são mais perceptíveis no âmbito qualitativo, no qual a organização identifica o aprimoramento das práticas operacionais principalmente quanto ao controle das atividades executadas, minimizando as falhas humanas na execução da rotina de trabalho.

Há ainda indícios de que um fator que pode contribuir para essa dificuldade na mensuração de resultado é o fato de que boa parte das empresas que implantam o sistema WMS o fazem com a finalidade de organizar e controlar melhor a sua operação. Como as atividades logísticas não eram devidamente monitoradas, os parâmetros de comparação dos cenários pré e pós-implantação do sistema ficam prejudicados.

Contribuindo para a geração de uma maior eficiência operacional, foram identificados (tanto nas empresas desenvolvedoras como nas usuárias do sistema) como tendências para o aprimoramento do WMS o desenvolvimento de relatórios customizados e de mais fácil visualização e análise para a tomada de decisão, bem como a integração com a tecnologia RFID. 
Esta pesquisa permitiu a identificação de dificuldades e benefícios não mencionados na literatura e que podem contribuir positivamente para o sucesso da implantação do WMS em empresas que utilizem a presente dissertação como fonte de informação.

Contudo, como limitações deste estudo, pode-se destacar o tamanho da amostra analisada, em virtude da dificuldade existente para que sejam encontradas empresas dispostas a participar de pesquisas acadêmicas. Dessa forma, os resultados aqui obtidos podem não refletir exatamente a realidade de algumas empresas desenvolvedoras ou usuárias do software de gestão da armazenagem.

Sugere-se, portanto, a realização de uma investigação de caráter quantitativo, a fim de ampliar a amostragem para que os indícios aqui identificados possam ou não ser confirmados. 


\section{REFERÊNCIAS}

ACCORSI, R.; MANZINI, R.; BORTOLINI, M. A hierarchical procedure for storage allocation and assignment within an order-picking system. A case study.

International Journal of Logistics Research and Applications. Bologna, v. 15, n. 6, p. 351-364, 2012.

ALVES, P. L. Implantação de tecnologias de automação de depósitos: um estudo de caso. 2000. 132 f. Tese (Doutorado em Administração) - Universidade Federal do Rio de Janeiro, Rio de Janeiro, 2000.

ANDRADE, M. M. Como preparar trabalhos para cursos de pós-graduação. São Paulo: Atlas, 2004.

ANG, M.; LIM, Y.; SIM, M. Robust Storage Assignment in Unit-Load Warehouse.

Management Science. Hong Kong, v. 58, n. 11, p. 2114-2130, 2012.

BAKER, P.; CANESSA, M. Warehouse design: a structured approach. European Journal of Operational Research, Bedford, n.193, p. 425-436, 2009.

BALLOU, R. H. Logística empresarial de transporte, administração de materiais e distribuição física. São Paulo: Atlas, 1993.

Gerenciamento da cadeia de suprimentos/logística empresarial. 5. ed. Porto Alegre: Bookman, 2006.

BANZATO, E. Tecnologia da informação aplicada à logística. São Paulo: IMAM, 2005.

BANZATO, E. et al. Atualidades na armazenagem. 3. ed. São Paulo: IMAM, 2010.

BARBOSA, L. Cultura administrativa: uma nova perspectiva das relações entre antropologia e administração. RAE, Revista de Administração de Empresas, São Paulo, v. 54, n. 3, p. 7-18, 1996.

BARDIN, L. Análise de conteúdo. São Paulo: Edições 70, 2011.

BHUPTANI, M.; MORADPOUR, S. RFID: implementando o sistema de identificação por radiofrequência. São Paulo: IMAM, 2005. 
BOWERSOX, D. J.; CLOSS, D. J. Logística empresarial: o processo de integração da cadeia de suprimento. São Paulo: Atlas, 2001.

. Logística empresarial. São Paulo: Atlas, 2007.

BOWERSOX, D. J.; CLOSS, D. J.; COOPER, M. B. Gestão da cadeia de suprimentos e logística. 2. ed. Rio de Janeiro: Elsevier, 2007.

CHIAVENATO, I. Introdução à teoria geral da administração. 8. ed. Rio de Janeiro: Campus, 2011.

CHIANG, D.; LIN, C;. CHEN, M. The adaptive approach for storage assigment by mining data of warehouse management system for distribution centers. Enterprise Information System. Taiwan, v. 5, n. 2, p. 219-234, 2011.

CHIEN-MING, C. ; GONG, Y.; KOSTER, B. ; NUNEN, J. A flexible evaluative framework for order picking systems. Production and Operations Management, Rotterdam, v. 19, n. 1, p. 70-82, 2010.

CHEN, L.; LANGEVIN, A.; RIOPEL, D. The storage location assignment and interleaving problem in an automated storage/retrieval system with shared storage. International Journal of Production Research. London, v. 48, n. 4, p. 991-1011, 2011.

COOPER, D. R.; SCHINDLER, P. S. Método de pesquisa em administração. 7. ed. Porto Alegre: Bookman, 2003.

COSTA, W. A.; GOBBO JUNIOR, J. A. Etapas de implementação de WMS: estudo de caso em um varejista moveleiro. GEPROS: Gestão da Produção, Operações e Sistemas, Bauru, v. 4, n. 4, p. 101-121, 2008.

DINTER, B.; LAHRMANN, G.; WINTER, R. Information Logistics as a Conceptual Foundation for Entreprise-Wide Decision Support. Journal of Decision Systems. St. Gallen, v. 19, n. 2, p. 175-200, 2012.

DROHOMERETSKI, E.; FAVARETTO, F. O impacto dos processos de controle de inventário na acuracidade de estoque: múltiplos casos em empresas industriais da grande Curitiba. In: ENCONTRO NACIONAL DE ENGENHARIA DE PRODUÇÃO, 30, 2010. São Carlos. Anais... São Carlos: ABEPRO, 2010. p. 1-13. 
FERNANDES, M. R. A integração entre o orçamento empresarial e o ERP. 2001. 169 f. Dissertação (Mestrado em Engenharia de Produção) - Universidade Federal de Santa Catarina, Florianópolis, 2001.

FLEURY, P. F.; WANKE, P.; FIGUEIREDO K. F. Logística empresarial: a perspectiva brasileira. São Paulo: Atlas, 2000.

GAMBERINI, R.; GRASSI, A.; MORA, C.; RIMINI, B. An innovative aproach for optimizing warehouse capacity utilization. International Journal of Logistics Research and Applications. Reggio Emilia, v. 11, n. 2, p. 137-165, 2008.

GIL, A. C. Como elaborar projetos de pesquisa. 4. ed. São Paulo: Atlas, 2009.

GU, J.; GOETSCHALCKX, M.; MCGINNIS, L. F. Research on warehouse operation: a comprehensive review. European Journal of Operational Research, Atlanta, v. 21, n. 1, p. 1-21, 2007.

HOFSTEDE, G. Identifying organizational subcultures: an empirical approach. Journal of Management Studies. California, v. 12, n. 3, p. 1-12, 1998.

INSTITUTO BRASILEIRO DE GEOGRAFIA E ESTATÍSTICA (IBGE). Contas nacionais trimestrais: indicadores de volumes e valores correntes. Rio de Janeiro, 2012. Disponível em:

$<$ http://www.ibge.gov.br/home/presidencia/noticias/noticia visualiza.php?id noticia=2 093>. Acesso em: 1 ago. 2012.

JOHNSON, A.; MCGINNIS, L. Performance measurement in the warehousing industry. IIE Transactions. London, v. 43, n. 3, p. 220-230, 2010.

KIESMULLER, G. P.; BROEKMEULEN, R. A. The Benefit of VMI strategies in a stochastic mult-product serial two echelon system. Computers \& Operations Research Eindhoven, v. 37, n. 1, p. 406-416, 2010.

KOSTER, R.; LE-DUC, T.; ROODBERGEN, K. J. Design and control of warehouse order picking: a literature review. European Journal of Operational Research, Rotterdan, v. 1, n. 182, p. 481-501, 2007.

KUTANOGLU, E.; LOHIYA, D. Integrated inventory and transportation mode selection: a service parts logistics system. Transportation Research, Austin, v. 1, n. 44, p. 665-683, 2007. 
LAKATOS, E. M.; MARCONI, M. A. Fundamentos de metodologia científica. 7. ed. São Paulo: Atlas, 2010.

LOEBBECKE, C.; POWELL, P. Competitive advantege from IT in logistics: the integrated transport tracking system. International Journal of Information Management, Koeln, v. 18, n. 1, p. 17-27, 1998.

LUDWIG, T. D.; GOOMAS, D. T. Performance, accuracy, data delivery, and feedback methods in order selection: a comparison of voice, handheld, and paper technologies. Jornal of Organizational Behavior Management, London, v. 27, n. 1 p. 37-41, 2008.

MADADI, A.; KURZ, M. E.; ASHAYERI, J. Multi-level inventory management decisions with transportation cost consideration. Transportation Research, Tilburg, v. 46, n. 1, p. 719-734, 2009.

MAIA JUNIOR, H. De helicóptero é mais barato. Revista EXAME, São Paulo, v. 46, n. 8, p. 54, 2012.

MARTINS, P. G.; ALT, P. R. C. Administração de materiais e recursos patrimoniais. 2. ed. São Paulo: Saraiva, 2006.

MASCARENHAS, A. O. Existe uma maneira brasileira de administrar? Uma discussão sobre a utilização do conceito de cultura na administração e antropologia. Revista Científica do IMAPES, Sorocaba, v.2 , n. 1, p. 35-40, 2004.

MEDA, M. A. Tecnologia da informação aplicada à logística: fundamentação e aplicabilidade de soluções de WMS em atacados e distribuidores brasileiros. 2009. 245 f. Projeto de Dissertação (Mestrado em Administração das Organizações) Faculdade de Economia, Administração e Contabilidade de Ribeirão Preto, Universidade de São Paulo, Ribeirão Preto, 2009.

MOELLER, K. Increasing warehouse order picking performance by sequence optimization. Procedia: Social and Behavioral Sciences, Pforzheim, v. 14, n. 20, p. 177-185.

OLIVEIRA NETO, A. A. Metodologia da pesquisa científica. 3. ed. Florianópolis: Visual Books, 2008. 
PEREIRA, S.; TOQUETTI, L.; RICCI, D.; DUARTE, J. Informática em logística: sistema WMS para gestão da armazenagem. Fasci-Tech Periódico eletrônico da FATEC, São Caetano do Sul, v. 1, n. 3, p. 148-162, 2010.

POZO, H. Administração de recursos materiais e patrimoniais: uma abordagem logística. 2. ed. São Paulo: Atlas, 2002.

RAMOS, A. S. M.; MELO, R. L. M. Impactos da implantação do WMS: um estudo a partir da percepção dos funcionários de uma indústria têxtil de grande porte. In: ENCONTRO NACIONAL DE ENGENHARIA DE PRODUÇÃO, 23., 2003. Outro Preto. Anais... Ouro Preto: ABEPRO, 2003. p. 1-8.

RATTNER, H. Liderança para uma sociedade sustentável. São Paulo: Nobel, 1998.

RFID "Identificação por frequência de radio". 2011. Disponível em: $<$ http://www.congressorfid.com.br/rfid/>. Acesso em: 8 ago. 2012.

RIBEIRO, P. C. C.; SILVA, L. A. F.; BENVENUTO, S. R. S. O uso do WMS como ferramenta de amparo a operações de armazenagem. In: CONGRESSO DA SOBER, 18., 2005, Ribeirão Preto. Anais... Ribeirão Preto: SOCIEDADE BRASILEIRA DE ECONOMIA E SOCIOLOGIA RURAL, 2005. p. 1-19.

RICHARDSON, R. J. Pesquisa social: métodos e técnicas. 3. ed. São Paulo: Atlas, 1999.

ROODBERGEN, K. ; VIS, I. A survey of literature on automated storage and retrieval systems. European Journal of Operational Research. Amsterdam, v. 194, n. 1, p. 343-362, 2009.

RODRIGUES, E. F. Logística integrada aplicada a um centro de distribuição: comparativo do desempenho do processo de armazenagem após a implementação de um sistema de gerenciamento de armazém (WMS). In SIMPÓSIO DE EXCELÉNCIA EM GESTÃO E TECNOLOGIA, 8., 2011, Resende. Anais... Resende: AEDB, 2011. p. 1-14.

RUIZ, J. A. Metodologia científica: guia para eficiência nos estudos. 5. ed. São Paulo: Atlas, 2002. 
RUTNER, S. M.; GIBSON, B. J.; WILLIAMS, S. R. The impacts of the integrated logistics system on electronic commcer and enterprise resource planning system. Transportation Research, Fayetteville, v. 39, n. 1, p. 83-93, 2003.

SAHIN, E.; DALLERY, Y. Assessing the impact of inventory inaccuracies within a Newsvendor framework. European Journal of Operational Research, ChatenaiMalabry, v. 197, n. 1, p. 108-118, 2009.

SALGADO JUNIOR, A. P. Abordagem conceitual para a adequação dos níveis de estoque ao longo da cadeia de suprimentos: a filosofia ERP II. 2004. 355 f. Tese (Doutorado em Administração) - Faculdade de Economia, Administração e Ciências Contábeis, Universidade de São Paulo, São Paulo, 2004.

SANDERS, N. R.; PREMUS, R. IT applications in supply chain organizations: a link between competitive priorites and organizational benefits. Journal of Business Logistics, Chicago, v. 23, n. 1, p. 65-83, 2002.

SANTOS, F. F. F. Características da cultura organizacional sob a óptica da cultura nacional: estudo etnográfico no Banco do Brasil S.A. 2005. $250 \mathrm{f}$. Dissertação (Mestrado em Administração das Organizações) - Faculdade de Economia, Administração e Contabilidade, Universidade de São Paulo, São Paulo, 2005.

SEVERINO, A. J. Metodologia do trabalho científico. 2. ed. São Paulo: Cortez, 2002.

SHIH, S. C.; HSU, S. H. Y.; ZHU, Z.; BALASUBRAMANIAN, S. K. Knowledge sharing - a key hole in the downstream supply chain. Information \& Management, Namdong, v. 49, n. 1, p. 70-80, 2012.

SLACK, N. Administração da produção. 3. ed. São Paulo: Atlas, 2009.

TAG RFID UHF - Ironside Slim - Condifex. São Paulo: Saint Paul, 2012. Disponível em: <http://www.rfid.ind.br/detalhes.php?id prod=49\&raiz=192\#.UCLeu01IT2B >. Acesso em: 8 ago. 2012.

TRKMAN, P.; MCCORMACK, K.; OLIVEIRA, M.; LADEIRA., M. The impact of business analytcs on supply chain performance. Decision Support Systems. Ljubjana, v. 49, n. 3, p. 318-327, 2010. 
TSENG, M. L.; WU, K. J.; NGUYEN, T. T. Information technology in supply chain management: a case study. Procedia - Social and Behavioral Sciences, London, n. 300, p. 257-272, 2011.

TWIST, D. C. The impact of radio frequency identification on supply chain facilities. Journal of Facilities Management, lowa, v. 3, n. 3, p. 226-239, 2004.

VAIDYANATHAN, G.; DEVARAJ, S. The role of quality in e-procurement performance: an empircal analysis. Journal of Operations Management. South Bend, v. 26, n. 1, p. 407-425, 2008.

VIANA, J. J. Administração de materiais: um enfoque prático. São Paulo: Atlas, 2002.

VIEIRA, S. Como escrever uma tese. 5. ed. São Paulo: Pioneira, 1991.

VIJAYASARATHY, L. R. An investigation of moderators of the link between technology use in supply chain and supply chain performance. Information and Management, Fort Collins, v. 47, n. 1, p. 364-371, 2010.

YAO, Y.; DRESNER, M. The inventory value of information sharing, continuous replenishment, and vendor-managed inventory. Transportation Research, Bethlehem, v. 44, n. 1, p. 361-378, 2008.

YIN, R. K. Estudo de caso: planejamento e métodos. 4. ed. São Paulo: Bookman, 2009.

YU, M. ; KOSTER, R. Enhancing performance in order picking processes by dynamic storage system. International Journal of Production Research. London, v. 48, n. 16, p. 4785-4806, 2010.

ZHOU, H.; BENTON JR, W. Supply chain practice and information sharing. Journal of Operations Management. Durham, v. 25, n. 1, p. 1348-1365, 2007. 


\section{APÊNDICE A - Roteiro de entrevista semiestruturada para os desenvolvedores do software WMS}
Empresa:
$N^{\circ}$. de funcionários
Data: Entrevistado:

Formação: Idade:

Cargo: Tempo de cargo:

1 - Na sua visão, atualmente as organizações têm conhecimento do que realmente é o WMS, quais são suas funcionalidades e reais benefícios?

2 - Pela sua experiência, aproximadamente que porcentagem das organizações conhece as funcionalidades do WMS que são oferecidas atualmente ao mercado? 3 - Da mesma forma, aproximadamente qual o percentual de empresas que adotam esse sistema de gestão e fazem uso adequado e pleno do que o WMS pode oferecer?

4 - Quais são as barreiras existentes para que as organizações façam uso completo das funcionalidades oferecidas pelo WMS?

5 - Quais são as novas funcionalidades oferecidas pelas empresas que desenvolvem o software WMS?

6 - Existem ou estão sendo desenvolvidas aplicações/funcionalidades que gerem benefícios para a cadeia de suprimentos e não somente para uma organização individualmente?

7 - Em caso positivo quais são essas funcionalidades e benefícios? Existem casos de empresas que já fazem uso dessas aplicações?

8 - Quais são as tendências para o desenvolvimento e aprimoramento do modelo de gestão da armazenagem WMS? 


\section{APÊNDICE B - Roteiro de entrevista semiestruturada para organizações usuárias do WMS}

Empresa: $N^{\circ}$. de funcionários

Data: Entrevistado:

Formação: Idade:

Cargo: Tempo de cargo:

1- Qual foi a principal questão que levou a organização a optar pela adoção do sistema WMS?

2- Os colaboradores envolvidos na operação de armazenagem tinham algum conhecimento sobre WMS?

3- Esses colaboradores sabiam das funcionalidades e benefícios oferecidos pela solução WMS?

4- Quais eram os objetivos e expectativas iniciais?

5- Quais foram os desafios encontrados?

6- Quais foram os benefícios percebidos?

7- Quais foram as adaptações de processos necessárias?

8- Quanto ao nível de estoque, o mesmo foi alterado após a implantação do WMS?

9- Qual foi o tempo necessário para a percepção de resultados efetivos?

10-Finalizada a implantação, qual a sua visão quanto ao projeto? As expectativas e objetivos iniciais foram atingidos? Há projeto de novas melhorias a serem adotadas? 